\title{
Středověký areál těžby stříbra Havírna u Štěpánova nad Svratkou: dokumentace v letech 2017-2019 a problém její interpretace
}

\author{
Medieval silver mining area Havírna near Štěpánov nad \\ Svratkou: Documentation in 2017-2019 and the issue \\ of its interpretation
}

- Jiři Doležel* -

\section{KEYWORDS:}

Silver mining - Bohemian-Moravian Highlands - Štěpánov/Havírna mining area $-13^{\text {th }}$ century - field survey - ground-based laser scanning

\section{ABSTRACT}

The thirteenth and fourteenth-century silver mining and processing site in the forest of Havirna is located 2.1 kilometres north-east of Štěpánov nad Svratkou in the Bohemian-Moravian Highlands and is among the best-preserved medieval mining sites in the Czech lands. The archaeological part of the current research project focuses on the precision surveying of the site using land-based laser terrain scanning. The outputs - a plan with the basic contour interval of $20 \mathrm{~cm}$ and a spatial visualisation - enable further characterisation of the whole complex of stopes. The ore accumulations were mined in three core shaft $z$ ones, within which the $13^{\text {th }} / 14^{\text {th }}$-century mine workings occupied a total area of 20.5 ha. The mine workings were accompanied by large contemporary mining settlements in several parts of the site and technical and administrative facilities and features were also detected. A parallel detector survey evidenced a rich, specific culture of the mining milieu as well as advanced technologies used for the exploitation and processing of ores. The remains of satellite and exploration mining activities in the wider area are also documented. The current study highlights the major potential of this site for research into medieval precious metal mining in a wider European context.

\section{* Corresponding author-E-mail address: dolezel@arub.cz}

\section{1. Úvod}

Rozsáhlé důlní stařiny v lesní trati Havírna (k. ú. Štěpánov nad Svratkou, Kraj Vysočina) náleží k nejzachovalejším areálům dobývání a dalšího zpracování stř́íbra ve 13. a 14. století v celoevropském rámci. Unikátní, intaktně ve svažitém terénu dochovaný komplex sdružuje vlastní těžební díla (přípovrchová i hlubinná), navazující úpravní a hutní pracoviště i relikty objektů důlní infrastruktury a četných hornických obydlí. Dosavadní archeologické studium lokality, rozvíjené od devadesátých let minulého století, upozornilo na její významný potenciál pro poznání procesu exploatace a zhodnocování drahých kovů v důležitém období českých dějin, zdůrazněný také v aktuálních odborných kompendiích (např. Žemlička 2014, 351-353; Klápště 2016, 182-183). Havírna je současně nejvýznamnějším historickým horním areálem štěpánovského polymetalického rudního revíru, rozsáhlé oblasti výskytů a těžby drahých i barevných kovů na západním okraji svratecké klenby moravika, ve vertikálně členité krajině Nedvědické vrchoviny (viz např. Houzar et al. 2000; Houzar, Malý 2002; s další literaturou; Sikora 2010; srov. obr. 1).

Samotné pomístní jméno Havírna, jakkoliv se již pro danou lokalitu prosadilo v odborné literatuře i obecném povědomí, je však přitom zřejmě novotvarem z období kolem poloviny minulého století, vytvořeným možná při geologicko-ložiskovém průzkumu revíru pro odlišení od dalších okolních báňských prací. Jak již bylo upozorněno (Sadílek 2014, 7, pozn. 5), veškeré historické kartografické prameny identifikují důlní areál typicky hornickým německým mikrotoponymem Cumberk, Zumberg, ve zřejmém významu „k hoře“, „k hornímu dílu“. Dnes jsou tak běžně charakterizovány pouze staré dobývky na protější straně údolí Záskalského potoka, na švařeckém katastru. Pokud bude v dalším výkladu respektováno stávající, zažité pojmenování Havírna, pak pouze s vědomím odlišného historického označení Cumberk, patrně středověkého nebo časně novověkého původu.

Geologicko-mineralogická prospekce, navazující v posledních třech desetiletích na starší báňské ověřovací práce, upřesnila charakteristiku ložiska i těžených rud, obsahujících vedle obecných sulfidů s převažujícím sfaleritem a galenitem v hojné míře i ušlechtilé minerály stř́ibra, zejména freibergit a pyrargyrit (např. Houzar, Malý 2002, 15, 26-29, 41, 43, 45, 54; Velebil, Kráčmar 2002, 170, 172; Malý, Dolníček 2005, 310, 312-318, obr. 2, 3, tab. 1-4: 10.1; Hrazdil, Houzar 2013, 12, 13, 18-20, 23, obr. 6, tab. 1, č. 19; Stránský et al. 2013b, 37-41, tab. I, III, IV; Grossmannová et al. 2014, 114-116). Geologicko-ložiskové studium areálu Romanem Štanclem přineslo také již roku 1979 prvé nepochybné archeologické doklady o stáří zdejšího dolování a intenzitě osídlení ve 13. století (Štancl 1980a, 19-20). Počáteční etapa soustavného povrchového archeologického průzkumu, realizovaného nejprve Jaroslavem Sadílkem a poté i Jiřím Doleželem 


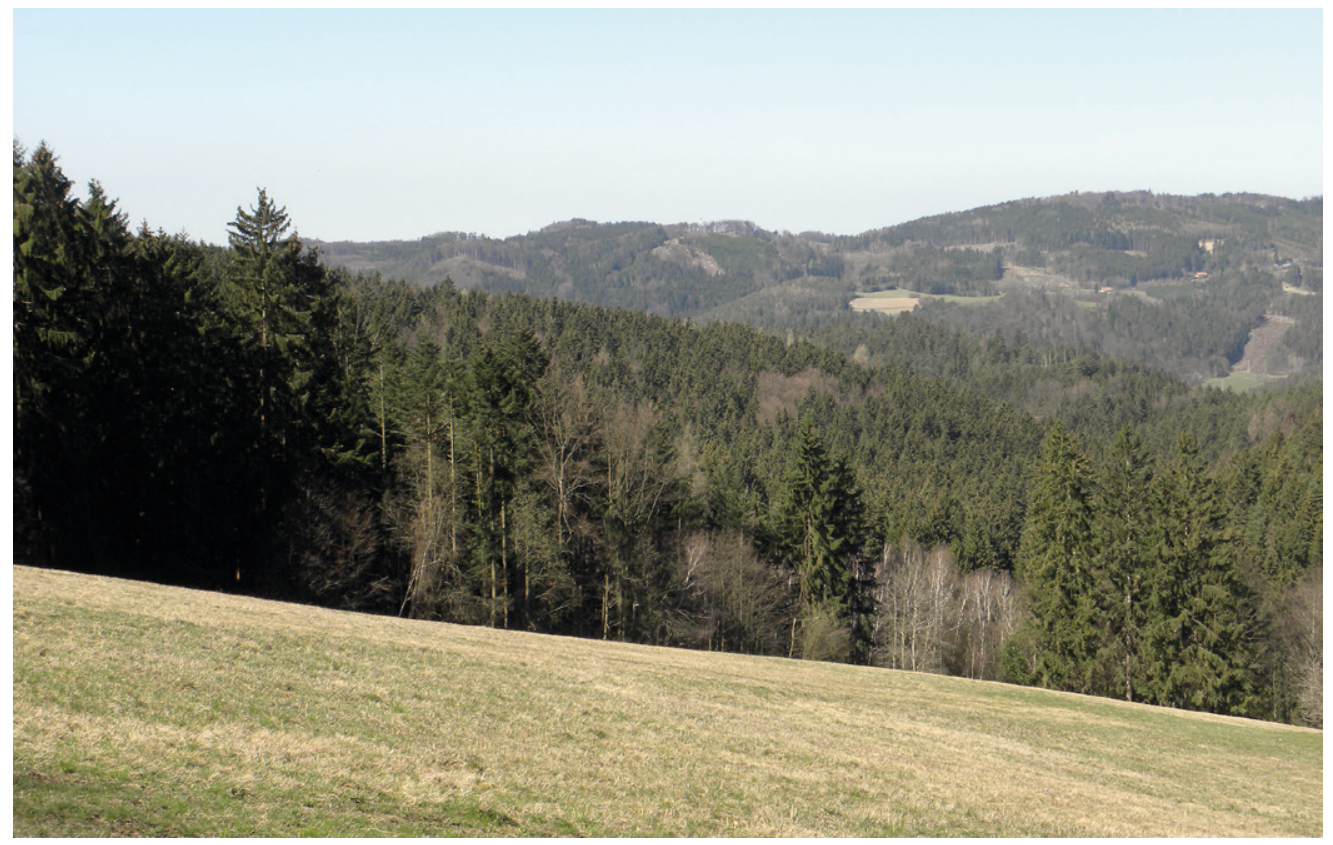

Obr. 1. Středověký areál těžby stř́bra Havírna u Stěpánova nad Svratkou. Panoramatický pohled na lokalitu od jihovýchodu, z pastviny pod samotou Hrachovce (k. ú. Čtyři Dvory). Vlastní montánní areál situován na zalesněném svahu ve střední části snímku. Na horizontu hluboce zaříznuté údolí řeky Svratky s převýšenými hřebeny hor Luzník, Jahodná a hradem Zubštejnem (v pravé části snímku). Foto J. Doležel, duben 2019.

Fig. 1. Medieval silver mining area Havírna near Štěpánov nad Svratkou. Panoramic view of the site from the south-east. The mining complex itself is situated on a wooded slope in the middle of the picture. A deep valley of the Svratka River on the horizon with the elevated ridges of the Luzník and Jahodná mountains and Zubštejn castle (in the right part of the picture). Photo by J. Doležel, April 2019.

z Archeologického ústavu AV ČR, Brno, v. v. i., ve spolupráci s dalšími institucemi i jednotlivci, byla v letech 1990-2001 zaměřena na základní poznání struktury lokality, získání nálezů pro dataci, na revizi a interpretaci písemných pramenů. Štěpánovskou Havírnu prezentovala jako neopevněné seskupení dobývek, doprovázených hornickými př́bytky, stejně jako navazujícími provozy, hutními i jinými. Areál, situovaný převážně ve svažitém terénu, zaujal celkovou plochu okolo 20 hektarů (obr. 2). Komparace písemných i archeologických pramenů umožnila otevření ložiska na Havírně položit k polovině 13. století, těžba pak vrcholila nejspíše v průběhu 3. čtvrtiny 13. věku. S koncem vlády krále Václava II. následoval zřejmě značný útlum prací, ve 14. století byla pro uchování kutacích práv udržována patrně již jen dědičná štola. Víceméně asi nepř́iliš úspěšné pokusy o obnovení exploatace proběhly v pozdním 15. a v 18. věku. Pozemkovou vrchností byli na Havírně po celý středověk páni z Medlova (či později z Pernštejna), určitá práva tu mohl nárokovat i augustiniánský klášter v Doubravníku. V těžbě drahých kovů v celém štěpánovském rudním revíru se však za Přemyslovců i Lucemburků rozsáhle angažoval městský, zejména brněnský patriciát. Podle pozdních dokladů z let 1348, 1350 a 1352 šlo zvláště o rod Goblinů, jejichž předek zastával na konci 13. století př́iznačně úřad mincmistra (souhrnně o této fázi výzkumu Doležel, Sadílek 2004; ke Goblinům Doležel 2002, 34-41, 44; přehledně o lokalitě s akcentem na její památkový význam Stránská 2015).

Druhá etapa archeologické prospekce Havírny pod záštitou Archeologického ústavu AV ČR, Brno, v. v. i., proběhla v letech 2002-2016. Vedle další plánové a fotografické dokumentace šlo zejména o soustavný průzkum detektorem kovů, realizovaný především Martinem a Jiřím Kejzlarovými, doplňkově pak Jiřím Doleželem. Z celé řady akcí pochází unikátní a obsáhlý, mnoho set kusů čítající soubor movitých artefaktů. Nálezy jednak znovu ověřily a upřesnily výše naznačenou dataci jednotlivých fází dobývek a osídlení, jednak potvrdily stěžejní místo lokality v rámci těžby stř́ibra ve štěpánovském rudním revíru v 2 . polovině 13. století. Jednotlivé nálezové kategorie přinášejí důležité indicie k vývoji vnitřní struktury celého komplexu, k technice exploatace a zpracování vydobytých rud i k materiální a duchovní kultuře hornických komunit 13. věku. Umožňují ale také nastínit funkční, profesní a sociotopografické členění areálu. Indikována byla existence $\mathrm{v}$ zásadě dvou ústř̌edních, časově následných sídelně-obslužných segmentů, zř̉ejmě s centrálními funkcemi v oblasti správy a organizace důlní práce. Starší, činný zejména v druhé polovině 13. století, byl situován prakticky ve středu lokality, v komunikačně nejvýhodnější poloze na okrajové terase nad terénním zlomem, rozčleňujícím důlní prostor do dvou elevačně odlišných dílů. Zásadně redukované osídlení 2 . poloviny 14 . věku se následně koncentrovalo pouze na nevelké ploše v severní, dolní části, nikoliv náhodou v blízkosti ústí dědičné štoly, zřejmě udržované ještě v polovině 14. století jako poslední horní dílo celého báňského podniku. Nálezy z prospekce let 2002-2016 rovněž opětovně vymezily další parciální sídelní a dílenské komponenty areálu.

Prezentace výsledků druhé výzkumné etapy proběhla zatím pouze ve formě předběžného referátu (Doležel, Kejzlar 2013), hlouběji analyzovány a zveřejněny byly některé výlučnější nálezové kategorie: „bronzové“ brakteáty, lotová závaží a úkap stř́ibra (Militký 2006, 245-246, 248-250, č. 6, 7, obr. 46: 6, 7, tab. 20; 2007, 56-57, 59-60, 66, č. 7, 8, obr. 2: 7, 8, tab. 1; Doležel 2008, 186-193, 200, 202, č. 9-11, obr. 6: 4, 7: 3, 5, obr. 10, tab. 1, 2; Hrubý 2014a, 624, 628, obr. 17: 9; 2016, 194, obr. 19: 9; Derner et al. 2016, 234, obr. 27: 10). Určitý omezený výběr nálezů rovněž nabídnul roku 2015 katalog tematické výstavy v Muzeu Vysočiny v Jihlavě (Hrubý et al. 2015, 18, 19, 27-36, obr. 52, 54-58, 83, 84, 88, 91, 93, 94, 96, 98, 101, 103-106, 109-111, 113, 114). Publikace bohaté kolekce materiální kultury štěpánovské Havírny tak zůstává naléhavým dluhem. Vhodným doplněním poznatků pak bylo upozornění na další, dosud nevyužitou písemnost z roku 1350, patrně související s podílem rodu brněnských Goblinů na těžbě stř́ibra na Štěpánovsku (Jan 2013, 487; cf. Flodr ed. 2005, 417, č. 1 175).

\section{Projekt dokumentace a prospekce 2017-2019}

Faktorem zásadně limitujícím další výzkum zůstávala na štěpánovské Havírně absence moderního podrobného geodetického zaměření lokality, plošně značně rozsáhlé, s extrémně rozrůzněným terénním reliéfem, intenzivně přetvořeným antropogenní činností. Pouze dostatečně podrobné zaměření celého areálu mohlo vytvořit bázi pro další základní dokumentaci, hlubší 
studium, památkovou ochranu i prezentaci naleziště, obdobně jako pro širší kulturně-historickou i technologickou interpretaci dochovaných pozůstatků dolování. Z jednotlivých témat jde zejména o vazbu těžby na konkrétní typ zrudnění, způsob a jednotlivé fáze rozměření důlních polí, o technologii dobývek, organizaci báňských i navazujících úpravních prací, funkční rozčlenění, relace hornického osídlení k přilehlým důlním pracovištím, komunitní a prostorovou infrastrukturu a další problémové okruhy. ${ }^{1}$

Stále nedostatečné bylo ale i poznání horního celku po stránce geologicko-ložiskové, mineralogické a metalurgické (konstatovali tak např. Hrazdil, Houzar 2011, 11-12): v širší perspektivě se právě tato data jeví jako zásadní pro objektivní posouzení významu štěpánovské Havírny v ekonomice českých zemí 13. století. Zevrubný geologický a mineralogický průzkum nabízel rozšírit informace o charakteru a potenciálu samotného ložiska, jeho zrudnění, druhovém složení a typice těžených rudních minerálů i pravděpodobném množství vytěženého drahého kovu. Obdobně analytika primárních i sekundárních produktů hutnění, na lokalitě doložených, podmiňovala dosažení informací o technologických postupech, aplikovaných zde při úpravě a tavbě vydobytých rud.

Pro řešení obou podstatných aktuálních problémů dalšího studia lokality byly v letech 2017-2019 získány finanční prostředky v rámci Programu regionální spolupráce pracovišt Akademie věd České republiky a Kraje Vysočina. Společný výzkumný projekt „Areál těžby stříbra 13. století Havírna u Štěpánova nad Svratkou - průzkum, dokumentace, prezentace a ochrana“ (identifikační číslo AV ČR R300011701), rovným dílem podporovaný Akademií věd České republiky a Krajem Vysočina, zaměřil svoji pozornost jak na prostorovou dokumentaci a další archeologické poznání místa samotného, tak na jeho ložiskové a metalurgické charakteristiky. Pod gesci Archeologického ústavu AV ČR, Brno, v. v. i. (vedoucí prací Jiří Doležel), spadalo vlastní podrobné zaměření lokality metodou pozemního laserového skenování, s následným vygenerováním souborného vrstevnicového plánu a 3D vizualizací jako východiska dalších výzkumných, ochranných i prezentačních postupů. Dokumentační práce doplnila pokračující prospekce celého areálu detektorem kovů, zajištěná Martinem Kejzlarem, orientační povrchový průzkum širšího zázemí Havírny a dalších hornických stařin štěpánovského rudního revíru provedl v letech 2019 a 2020 rovněž Jiří Doležel. Muzeum Vysočiny Jihlava, p. o., jako odborná instituce zřízená Krajem Vysočina (vedoucí prací Karel Malý) uskutečnilo v rámci projektu podrobný mineralogický výzkum rud těžených na Havírně, šlichovou prospekci Záskalského potoka v místech těžby i v navazujících úsecích, analytické studium chemického a fázového složení hutních strusek, stejně jako chemické a fázové analýzy kovových slitků, nalezených detektorovým průzkumem, at již šlo o surovinné substance, fázové meziprodukty nebo produkty cílové.



Obr. 2. Středověký areál těžby stříbra Havírna u Štěpánova nad Svratkou se širším zázemím na Základní mapě České republiky $1: 10000$ (Metadata) ve stavu z roku 2020. Samotná lokalita položena ve střední části mapové výřezu. @ Český ústav zeměměřičský a katastrální, návrh J. Doležel, technické zpracování M. Hlavica, 2020.

Fig. 2. Medieval silver mining area Havírna near Štěpánov nad Svratkou with its broader surroundings on the Basic Map of the Czech Republic 1: 10,000 (Metadata) as of 2020. The site itself is located in the middle of the map view. (C) Czech Institute of Surveying, Mapping and Cadastre, design by J. Doležel, technical adjustments by M. Hlavica, 2020. 
Výstupy projektových prací v obou segmentech vytvářejí kvalitativně novou bázi pro další poznání této klíčové lokality i pro její památkovou ochranu a prezentaci širší veřejnosti. Prozatímní rezultáty v oblasti studia exploatovaných rud na Havírně a jejich metalurgického zpracování až po výsledné kovy přináší souhrn Karla Malého v časopisu Muzea Vysočiny v Jihlavě Acta rerum naturalium (Malý 2020). Zde předkládaný př́íspěvek resumuje předběžné výsledky vlastní dokumentace důlního areálu, zejména co se týče nových poznatků o jeho vnitřním uspořádání, charakteru a rozsahu důlních prací, možných úpravních a hutních provozech i obslužné a obytné infrastruktuře. Úroveň získaných informací dovoluje v tomto ohledu významně zpřesnit a rozšířit závěry formulované v prvém komplexnějším zpracování (Doležel, Sadílek 2004). Text však také zcela záměrně šířeji nastiňuje možný potenciál nově nabytých dat ve výkladových či přímo interpretačních úrovních, v komparaci s výsledky montanistického bádání v českých zemích i v Evropě; v této perspektivě je zamýšlen jako předstupeň možného monografického zpracování lokality. Rezignuje naopak na analýzu místa a významu Havírny v rámci štěpánovského rudního revíru i její pozice v dobových majetkově-správních, sídelních, komunikačních a ekonomických strukturách, stejně jako na nástin či rozbor movitého nálezového fondu a hmotné kultury; tyto aspekty budou sledovány dalším samostatným studiem.

\section{Podrobné zaměření důlního areálu, problematika interpretace}

\subsection{Vývoj kartografického znázornění Havírny}

Vlastní komplex štěpánovské Havírny kupodivu chybí na dosud známých, poměrně početných historických horních mapách jednotlivých báňských děl štěpánovského rudního revíru, pořizovaných ve 3. čtvrtině 18 . století pro potřebu periodicky obnovovaných důlních prací (např. Houzar 1998b, 73, 79, obr. 1; Houzar et al. 2000, 118, 120, 121, 124, 128, obr. 2-5, 7; Houzar, Malý 2002, 18, obr. 9; Velebil, Kráčmar 2002, 168). Prospekční aktivity přitom probíhaly jak prrímo na samotné lokalitě (1774 štola
František v severozápadním cípu důlního pole), tak v bezprostředním okolí: v letech 1768 a 1772 byla mapována kupř́íkladu i šachta a štola Cumberk na protější straně údolí Záskalského potoka (Houzar et al. 2000, 121-122, obr. 4).

Nejstarším povědomým kartografickým znázorněním areálu Havírny tak zůstává schématická polohopisná mapa důlních stařin na katastru Borovce a Štěpánova v pojednání Maxe von Wolfskrona z roku 1889 o moravských výskytech zlata (obr. 3). Poskytuje ovšem pouze povšechnou představu o základním směrování tří hlavních těžených žilných pásem (Wolfskron 1889, 236, tab. V, obr. 1; srov. též Houzar 1998a, 23, obr. 2; Doležel, Sadílek 2004, 59, 52, obr. 4). Patrně ze tř̌icátých nebo čtyřicátých let 20. století pochází pak první podrobnější zaměření, uložené v pozůstalosti geologa a mineraloga Adolfa Poláka v archivu Mineralogicko-petrografického oddělení Moravského zemského muzea v Brně (k osobnosti Adolfa Poláka srov. např. Jurman 1985, 151-152; 2014, 249-251). Plán, zakreslený do podkladové katastrální mapy $1: 2880$, především výstižně postihnul koncentraci původních dobývek do tř́i stěžejních obvalových tahů i jejich průběh a směrování, včetně př́íčného, na jedenáctou hodinu orientovaného pásu (obr. 4). Vcelku reálně byly vyjádřeny rovněž vzájemné vzdálenosti jednotlivých částí důlního prostoru, k určitým posunům došlo patrně vinou značné výškové členitosti. Mapování však zřejmě zůstalo nedokončeno, chybí zejména komplexnější zachycení reliktů těžby v plochách mezi nejvýznačnějšími liniemi obvalů a v okrajových partiích celé lokality.

Specifickou etapu dokumentace havírenského exploatačního areálu znamenaly zevrubné ložiskově průzkumné geologické práce, prováděné zde v padesátých a šedesátých letech minulého století (srov. např. Houzar, Malý 2002, 11, 19-21, $\mathrm{s}$ další literaturou). V jejich průběhu byla mimo jiné vyzmáhána a v měřítku 1:200 Milanem Šoubou roku 1959 zaměřena stará hledací štola v severozápadní okrajové části důlního pole, v délce 30 m ražená pod severní obvalový tah, sekundárně označovaná jako štola Václav (Štancl 1980a, prŕiloha č. 9; 1980b, př́íloha č. 10; srov. obr. 5). ${ }^{2}$

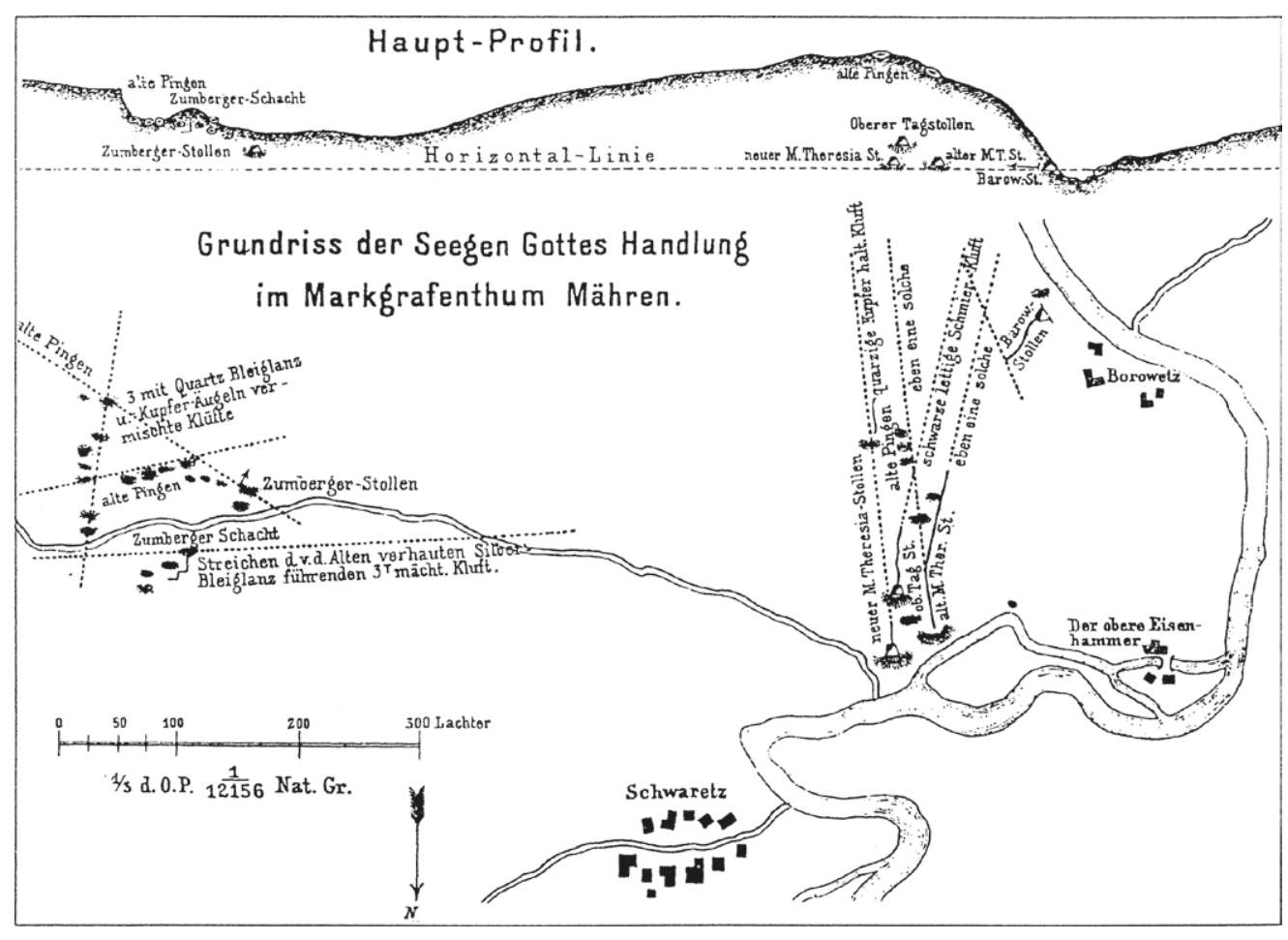

Obr. 3. Štěpánovský rudní revír. Historické důlní práce na katastrech Borovce, Štěpánova nad Svratkou a Švařce, znázorněné ve stavu z osmdesátých let 19. století na mapovém schematu a převýšeném profilu v článku M. v. Wolfskrona (1889, 236, tab. V, obr. 1). Vpravo při ohybu řeky Svratky stařiny v Záskalí (stará a nová štola Marie Terezie, Denní štola a obvaly na Němečkově kopci), jižněji u samotného Borovce štola Bárov. Vlevo pak typická trojúhelná struktura obvalových pásem na vlastní Havírně s Cumberskou štolou, naproti přes silnici Cumberská šachta s okolními horními díly.

Fig. 3. Štěpánov ore district. Historical mine workings in the cadastres of Borovec, Štěpánov nad Svratkou and Švařec, shown in their state from the 1880s in a map diagram and an elevated profile in the article by $M$. V. Wolfskron (1889, 236, tab. V, Fig. 1). On the right, at the bend of the Svratka River: the abandoned mines in Záskalí (the Old and New Maria Theresa adits, the Day adit and the pits and spoil heaps on Němečkův hill), the Bárov adit south of Borovec. On the left: a typical triangular structure of strips of pits remains at Havírna itself with the Cumberk adit, opposite the Cumberk shaft with the surrounding pits. 
Významný posun v kartografickém znázornění Havírny přinesla mapová skica, ve dvou variantách vypracovaná jako př́loha diplomové a následně i rigorózní práce roku 1979 Romanem Štanclem, částečně s využitím podkladů Libuše Češkové (Štancl 1980a, př́loha č. 7; 1980b, př́íloha č. 8). Předností je zejména komplexnost, s jakou autor zobrazil téměř veškeré území těžby, včetně periferních a obtížně rozlišitelných antropogenních struktur, zvláště při východním a jižním obvodu plochy (obr. 6). Pečlivě evidoval také další pozůstatky báňských aktivit v okolí, kupř́íkladu výraznou skupinu patrně prospekčních jam a obvalů na severovýchodě, na druhé straně potočního úžlabí. Současně orientačně zaznamenal hloubky pozůstatků dolování. Skica však nedostatečně diferencovala významná horní díla od podružných povrchových stop kutání či jiných útvarů, vzniklých zčásti patrně působením přírodních procesů, opět vykázala určité prostorové disproporce a musela vypustit některé partie, tehdy nepřístupné v hustém lesním porostu. Vzhledem ke zvolenému měřítku (1:1000) zůstalo rovněž až na nejmarkantnější objekty víceméně schematické zpodobnění jednotlivých reliéfních reliktů těžby. Právě toto zaměření bylo pro svoji úplnost široce využito při dalším studiu, v upravené a doplněné podobě se objevilo v popisu horních děl štěpánovského rudního revíru roku 2000 (Houzar et al. 2000, 129, obr. 8). Rovněž při zpracování výzkumů let 1990-2001 posloužilo jako podklad pro publikovaný orientační náčrt, dále modifikovaný, začleněný do vrstevnicové soustavy a doplněný o nová zjištění (Doležel, Sadílek 2004, 51, obr. 5). I po těchto úpravách se ovšem jednalo o pouze povšechné, informativní vyobrazení.

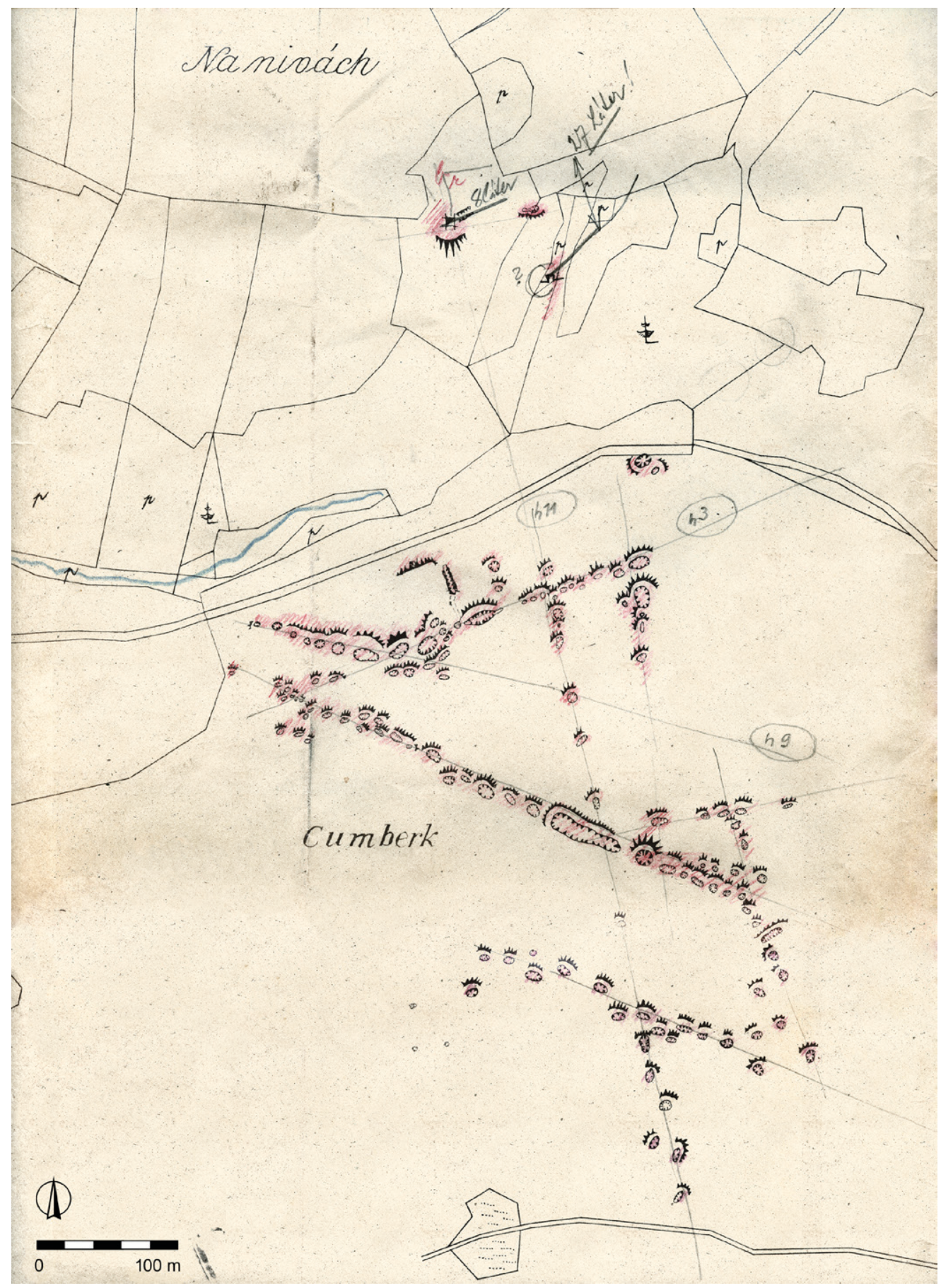

Obr. 4. Středověký areál těžby stříbra Havírna u Štěpánova nad Svratkou. Zaměření nejmarkantnějších důlních stařin A. Polákem do podkladové katastrální mapy $1: 2880$ v situaci patrně ze třicátých nebo čtyřicátých let 20. století. Vedle vlastní Havírny na jihu eviduje mapa také tzv. Cumberskou šachtu a štolu na severní straně úžlabí Záskalského potoka, na švařeckém katastru, zde zcela zřejmě na základě důlní mapy J. Ch. Urbana z roku 1772. (c) Archiv Mineralogickopetrografického oddělení Moravského zemského muzea vBrně.

Fig. 4. Medieval silver mining area Havírna near Štěpánov nad Svratkou. Mapping of the most striking abandoned mines by $A$. Polák on the underlying cadastral map 1:2,880 in a situation probably from the $1930 \mathrm{~s}$ or 1940s. In addition to Havírna in the south, the map also depicts the so-called Cumberk shaft and a adit on the northern side of the Záskalský stream gorge, in the Švařec cadastre, here apparently on the basis of the mining map of J. Ch. Urban from 1772. (c) Archive of the MineralogicalPetrographic Department of the Moravian Museum in Brno. 
V letech 2008-2010 uskutečnili rozsáhlé mapování hornických stařin štěpánovského rudního revíru pracovníci odboru bezpečnosti hornické krajiny státního podniku Diamo, odštěpného závodu Odra v Ostravě. Stalo se tak v rámci programu Ministerstva životního prostředí České republiky, dotujícího průzkum, zabezpečení a př́ípadnou sanaci starých důlních pracív některých regionech (srov. Křístek 2010; Veselý, Perlín 2010, 4, 7). Výsledkem geodetických prací, vedených Miroslavem Sikorou, byly vedle celkového kartografického přehledu historických důlních děl revíru i podrobnější mapy jednotlivých horních lokalit, včetně štěpánovské Havírny (Sikora 2010). Šlo o prvé exaktní, plošně úplné zaměření exploatačního areálu, velkou předností výsledného plánu je takřka úplné zachycení všech projevů důlní činnosti v terénu, včetně rozptýlených obvalů v periferních jižních a východních partiích plochy (obr. 7). Standardizované, schematické zobrazení reliéfních pozůstatků těžby systémem jednotných grafických značek, bez zohlednění jejich individuálního utváření, ale - při měřítku originálu 1:1000 - opět zásadním způsobem limitovalo podrobnější analýzu charakteru, vývoje, vzájemných relací a posloupnosti dobývek i dalších antropogenních útvarů na lokalitě (cf. kupř. Nováček 2001, 282-284; Večeřa 2004; 2017 a další tituly uvedené výše). Pominuty byly rovněž téměř veškeré terénní relikty lidských aktivit mimo vlastní hornickou činnost, zejména sídelní a dílenské terasy i rezidua vlastní zástavby.

\section{DŮLNI MAPA VYZMÁHANÉHO STARÉHO DUீLNIIHO DÍLA ŠTOLA VÁCLAV Př́l一oha Č. 10}

Štola Václav

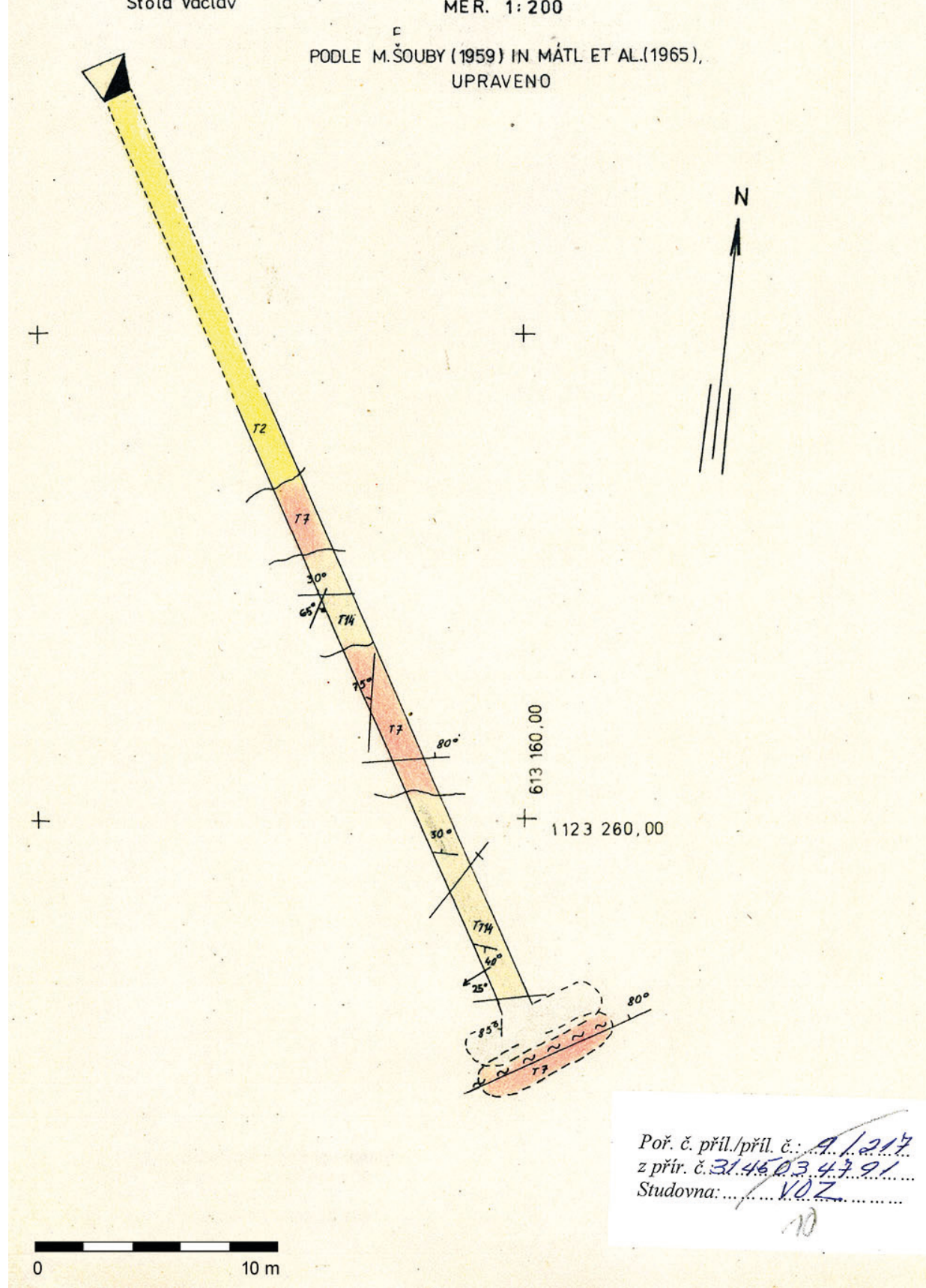

Obr. 5. Středověký areál těžby stř́bra Havírna u Štěpánova nad Svratkou. Důlní mapa vyzmáhané hledací štoly Václav v severozápadní části exploatační plochy, roku 1959 pořízená M. Šoubou. Podle R. Štancla (1980b, př́loha č. 10). (c) Přírodovědecká fakulta Masarykovy univerzity.

Fig. 5. Medieval silver mining area Havírna near Štěpánov nad Svratkou. Mining map of the prospecting adit Václav in the north-western part of the mining complex, made in 1959 by M. Šouba. According to R. Štancl (1980b, Annex No. 10). (c) Faculty of Science, Masaryk University. 
Prudký rozvoj leteckého laserového skenování při detekci a dokumentaci archeologických objektů (obecně pro české prostředí např. Starková 2010; John, Gojda 2013; 2017, 290-315) dramaticky změnil možnosti studia a objektivního postižení také $\mathrm{v}$ případě charakterem i rozsahem zcela specifické kategorie hornických stařin. ${ }^{3}$ Rovněž při památkové prezentaci Havírny byla využita data digitálního modelu reliéfu České republiky 5 . generace (DMR 5G), prezentovaný snímek (Stránská 2015, 364) představil přehledně celou lokalitu s nejpodstatnějšími obvalovými tahy na jednotlivých rudních strukturách i široké zóny vedlejších či prospekčních dobývek.

\subsection{Pozemní laserové skenování lokality}

Cílem dokumentační části projektu let 2017-2019 bylo podrobné zaměření terénního reliéfu důlního areálu, jež by při minimalizaci subjektivní interpretační perspektivy vytvořilo spolehlivou, objektivní bázi pro následnou analýzu a funkční i časoprostorovou klasifikaci a interpretaci jednotlivých antropogenních objektů i jejich pozice a zapojení do systémové struktury v rámci dílčích segmentů i lokality jako celku. Vedle určitějšího poznání parciálních funkčních složek horního „cechu“ (vlastní dobývky, sídlištní areály, centrální a obslužné body, úpravní, hutní a dílenské provozy apod.) šlo zejména o vytvoření možnosti identifikovat právní a provozní rozměření těžebních polí na konkrétní nálezné a důlní míry, stejně jako specifikovat organizaci a držbu dolového majetku i právně-technické formy exploatace a zhodnocení dobývaných rud (srov. pro prostřredí českých zemí zejména Večeřa 2004, 150-155; 2007; 2013). Vedle metod klasické kontaktní geodézie bylo možné uvažovat o cíleném pořízení digitálního modelu reliéfu (DMR) některou z forem laserového skenování (LIDAR), at již klasickým leteckým snímkováním (ALS - Airborne Laserscanning), vzdušným snímkováním za užití bezpilotních technologií (zejména s pomocí dronu: UAV - Unamanned Aerial Vehicle), nebo laserovým skenováním pozemním. Zásadním korelujícím prvkem pro volbu optimálního způsobu zaměření zůstával přitom požadavek maximální objektivity, přesnosti a podrobnosti zobrazení na straně jedné, na straně druhé značný plošný rozsah lokality, její silná vertikální členitost, vysoká četnost, hustota a komplikované utváření dokumentovaných antropogenních terénních útvarů, ale i tehdejší vegetační pokryv (většinou hustý vzrostlý smrkový porost, pouze v jihozápadní části místy nahrazený bukovým zmlazením). Jako nejvhodnější se za těchto okolností jevila aplikace pozemního laserového skenování. Pokusně se tato metoda v prostředí středověkých důlních lokalit uplatnila kupř́íladu již roku 2013 při zaměření reliéfních pozůstatků domu č. III na hornickém sídlišti Kremsiger v Krušných horách (Derner 2018a, 224, 226, obr. 122; měření provedl Vladimír Brůna z Univerzity Jana Evangelisty Purkyně v Ústí nad Labem: viz Brůna, Pacina 2014, 31, 36-37, obr. 10-12). Možnosti jejího širšího plošného využití pak byly testovány a ověřeny při dokumentaci menšího (okolo 1,8 ha), nově identifikovaného areálu těžby stříbra v lesní trati Království u Vratěnína na jihozápadní Moravě (16. století; výzkum Jiří Doležel, Archeologický ústav AV ČR, Brno, v. v. i.; měřičské práce realizoval roku 2015 Miloš Tejkal).

Zaměření důlního areálu Havírna detailním pozemním laserovým skenováním terénu bylo provedeno na základě zadání řešitele projektu v terénním pásu (segmentu) $765 \times 545 \mathrm{~m}$, na ploše přibližně 26,44 ha. Měřičské práce, zpracování získaných dat a následné generování jednotlivých výstupů digitálního modelu terénu zajistil Ing. Miloš Tejkal se svými spolupracovníky. Př́islušná polygonová sít byla vytýčena pulsní totální stanicí
Topcon GPT-3005LN a GNSS aparaturou Topcon Hiper+, pro vlastní skenování posloužily statické laserové skenery Faro Focus X130, Faro Focus X330 HDR a mobilní skener ZEB 1. Terénní část dokumentace probíhala po tři roky vždy ve vegetačně př́íznivém jarním období, při minimálním podrostu a olistění stromů a keřu - jednotlivé etapy měření se uskutečnily ve dnech 10. až 12 . dubna 2017, 23. března až 11 . dubna 2018 a 20. až 25. března 2019 (blíže k metodice měření Tejkal 2017-2019). Průměrná hustota bodů pořízených v terénu činila 3991 bodů na $\mathrm{m}^{2}$, vybraných bodů terénu pak 74 bodů na $\mathrm{m}^{2}$.

Výsledný digitální model terénu (DMT) byl předán v těchto výstupech:

- Vrstevnicové znázornění DMT: základní vrstevnice jsou po filtraci a simplifikaci tvaru vykresleny s intervalem $0,2 \mathrm{~m}$, hlavní vrstevnice $\mathrm{s}$ intervalem $1 \mathrm{~m}$. Vrstevnice byly dodány v souboru formátu DGN (Microstation) a PDF.

- Pravidelná sít: DMT znázorněn pravidelnou čtvercovou sítí bodů s rozestupem $0,2 \mathrm{~m}$, produkt je ve formátu DGN a v textovém formátu ASCII.

- Př́mo zaměřené laserové body reprezentující digitální model terénu byly zapsány ve formátu LAS1.2. Digitální model terénu byl vystínován a nasnímán z různých směrů, výsledná vyobrazení jsou vytvořena ve formátu jpg.

Zaměření prokázalo vysokou efektivitu uplatněné metody při dokumentaci rozlehlých, extrémně členitých a geomorfologicky komplikovaných komplexů antropogenních reliktů středověké důlní činnosti a přidružených aktivit. Získané výstupy, zejména vygenerování vrstevnicového plánu se základním intervalem vrstevnic $0,2 \mathrm{~m}$, ale i další variantní znázornění, umožňují na odpovídající úrovni rozvíjet další dokumentaci a vědecký výzkum lokality. Stejně tak jsou významné pro památkovou ochranu, edukaci a popularizaci Havírny i jiných historických důlních děl štěpánovského rudního revíru. Standardizace postupů pozemního laserového skenování při zaměřování horních stařin v obou zmíněných areálech (Vratěnín, Štěpánov - Havírna) podnítila konečně jejich aplikaci také v jiných báňských okrscích. Pro Národní památkový ústav, územní odborné pracoviště v Ostravě, tak jsou od roku 2017 Milošem Tejkalem dokumentovány pozůstatky hornických prací v Jeseníkách, zejména $\mathrm{v}$ andělskohorském a nově rovněž zlatohorském rudním revíru.

\subsection{K interpretaci prostorové, funkční a komunitní infrastruktury štěpánovské Havírny}

Podrobné zmapování otevírá zejména možnost objektivního funkčně-strukturálního, technického i kulturně-historického studia a interpretace celého důlního areálu (obr. 8-10). Jak bylo vyloženo, jde o objasnění vlastní technologie dobývek a technicko-právní organizace exploatace, postupů další úpravy a zpracování vytěžených rud, a současně o poznání správních a sídlištních komponent horního komplexu jako specifické formy středověké sídelní struktury. ${ }^{4}$ Nezbytným mezičlánkem zůstává ovšem detailní identifikace, analýza a následná interpretace všech mapováním zachycených antropogenních reliktů na lokalitě jak ve smyslu formálně-funkčním, tak z hlediska časového zařazení a (zejména $\mathrm{v}$ př́ípadě samotných důlních prací) horizontální i vertikální stratigrafie. Předběžně lze nicméně charakterizovat výchozí terénní nálezovou situaci na Havírně a připojit více či méně obsáhlý komentář jak k báňským dílům a jejich možnému rozměření i systémovému uspořádání, tak k organizaci sídlištních složek horního areálu, ke zpracovatelským provozům a možné existenci sakrální stavby přímo v prostoru exploatace. 


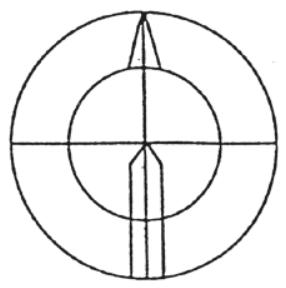

R. ṠTANCL 1979

(.ंE ṠKOVÁ
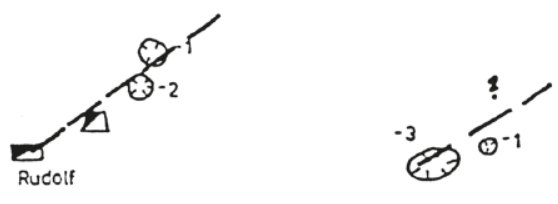
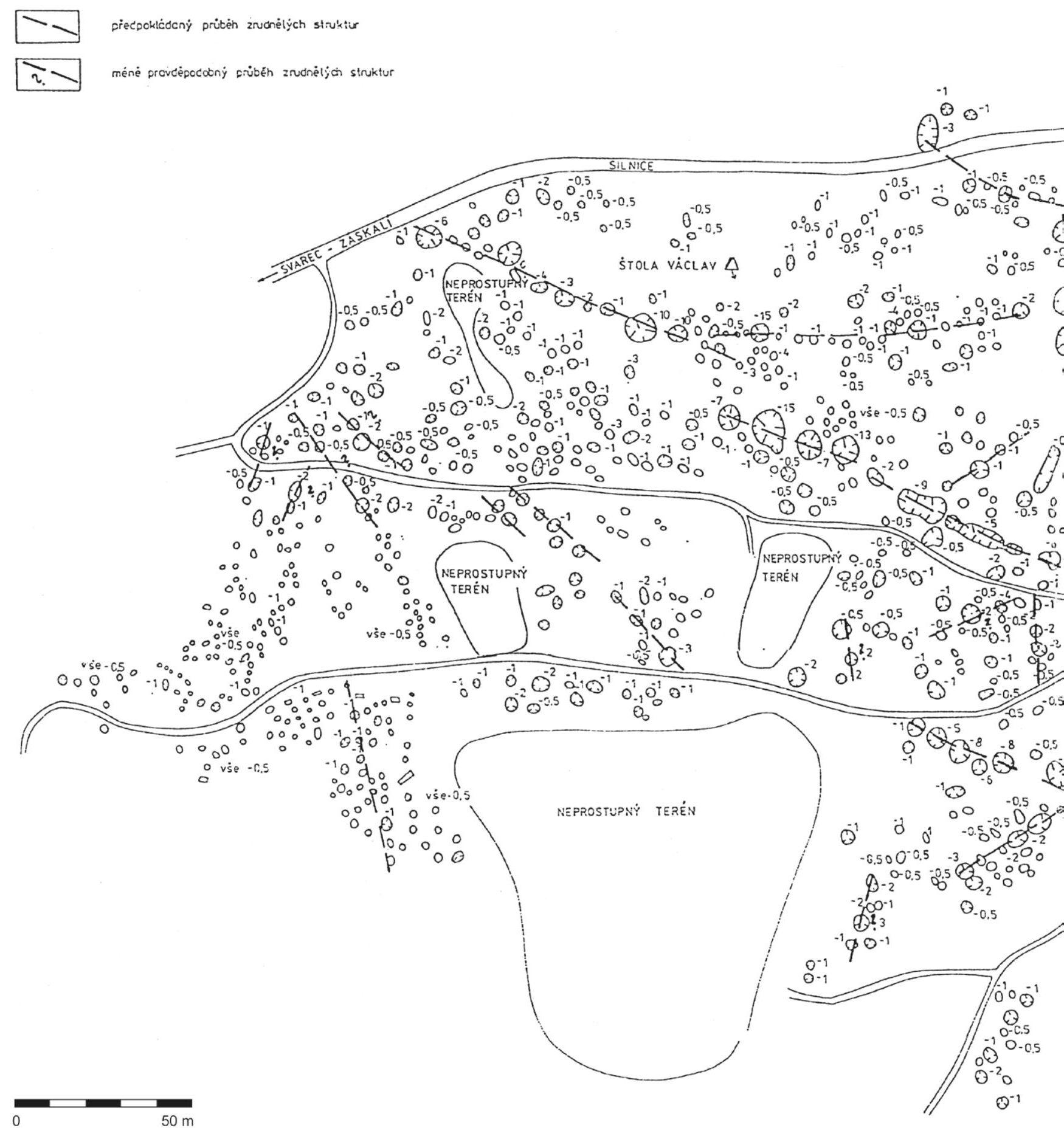


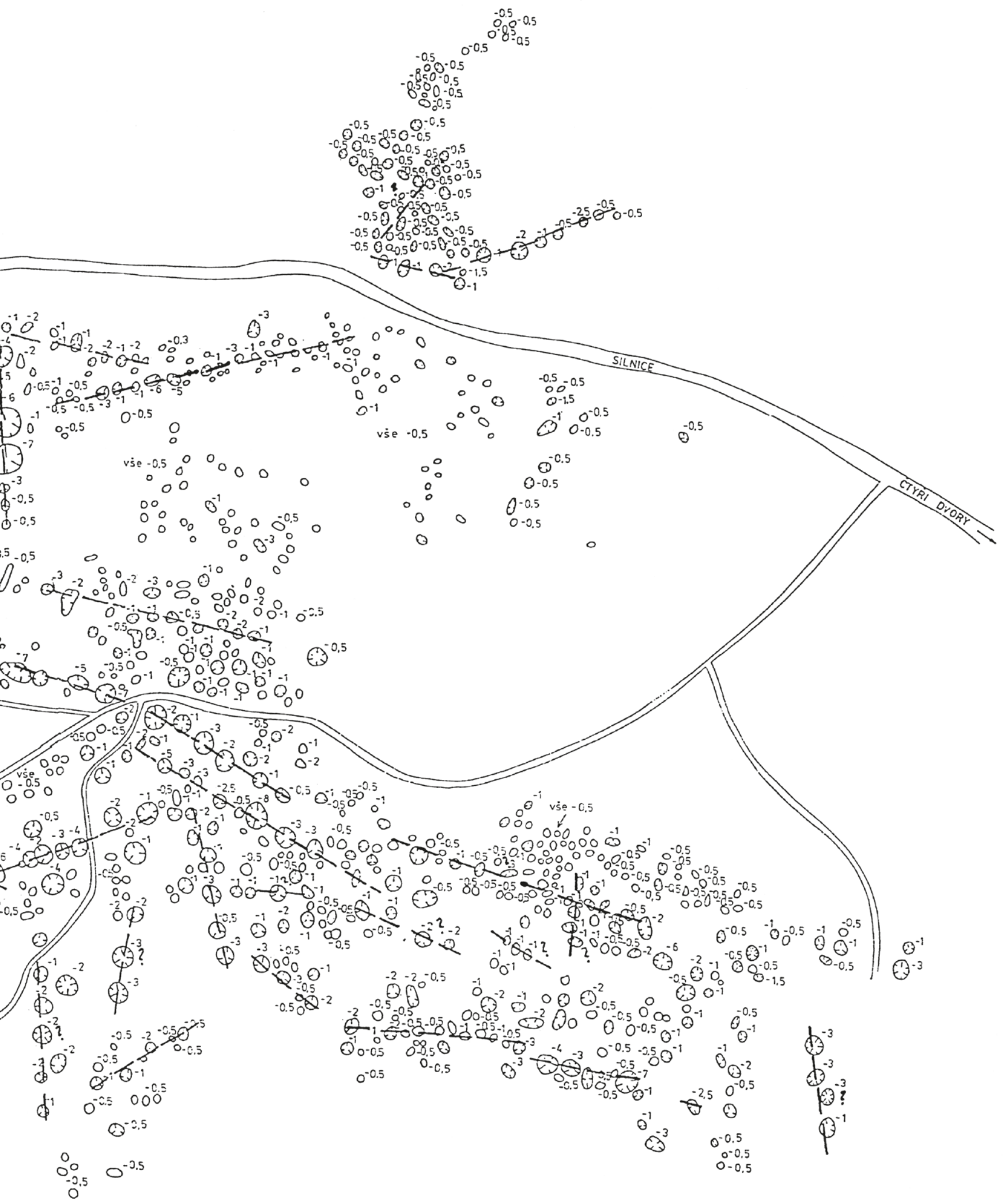

Obr. 6. Středověký areál těžby stříbra Havírna u Štěpánova nad Svratkou. Celková plánová skica lokality, vyhotovená roku 1979 R. Štanclem s částečnou pomocí podkladů L. Češkové (Štancl 1980b, příloha č. 8). ( ) Přírodovědecká fakulta Masarykovy univerzity.

Fig. 6. Medieval silver mining area Havírna near Štěpánov nad Svratkou. A complete plan sketch of the site, made in 1979 by R. Štancl with partial assistance from L. Češková (Štancl 1980b, Annex No. 8). (c) Faculty of Science, Masaryk University. 


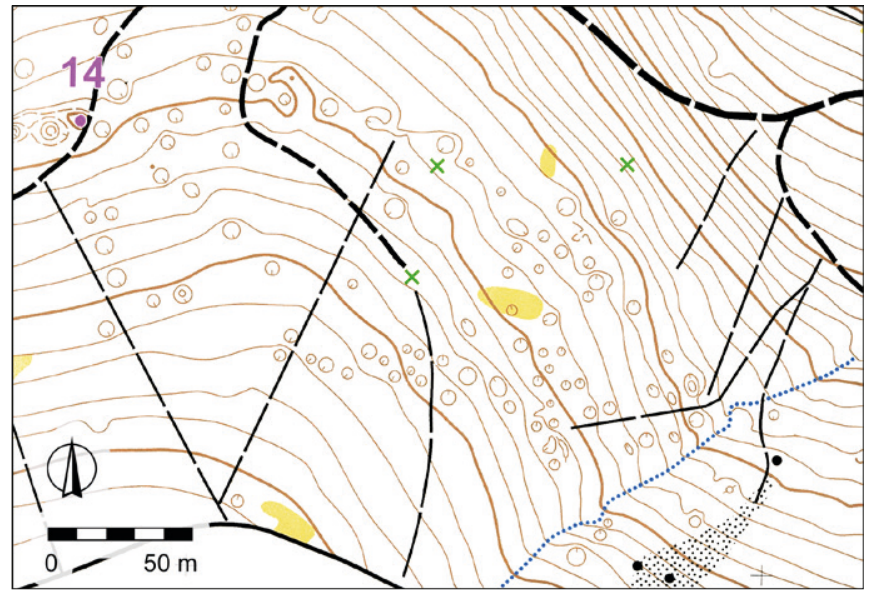

Obr. 7. Středověký areál těžby stř́bra Havírna u Štěpánova nad Svratkou. Dílčí výřez z geodetického zaměření důlních prací, v letech 2008-2010 realizovaného M. Sikorou (jihovýchodní zakončení středního a jižního pásma obvalů). (c) Odbor bezpečnosti hornické krajiny státního podniku Diamo, odštěpný závod Odra v Ostravě.

Fig. 7. Medieval silver mining area Havírna near Štěpánov nad Svratkou. Partial cutout from the geodetic mapping of mine workings, carried out in the years 2008-2010 by M. Sikora (south-eastern end of the middle and southern zone of the pits). (c) Department of Mining Landscape Safety of the state enterprise Diamo, Odra branch plant in Ostrava.

\subsubsection{Důlní díla, otázka dědičné štoly a aplikovaných horních měr}

Reliéfní stopy dávných báňských dobývek, průzkumných prací a dalších objektů souvisejících s provozem dolů v štěpánovské lesní trati Havírna lze zaznamenat na ploše 20,45 ha; další ojedinělé šachtice se nacházejí za východním koncem aktuálně dokumentovaného areálu. Ze tř́i stěžejních tahů šachet či povrchových výrubů, odkrývajících rudní akumulace v jednotlivých směrných žilných pásmech, dva jižnější sledují příslušné rudní žíly v zásadě od SZZ vzhůru do svahu JVV směrem, v polovině svého průběhu se poté rovnoběžně stáčejí prakticky $\mathrm{k}$ jihovýchodu (obr. 8, 9, 11, 12). Nejsevernější pás obvalů zachovává směrování SZZ-JVV pouze ve spodní severnější třetině, poté se výrazně lomí a probíhá naopak po vrstevnici k SVV (obr. 8, 10, 13-15). Stř̌ední pruh starých prací, na severozápadě zdvojený, dosahuje souhrnné délky nejméně $610 \mathrm{~m}$, nepř́liš̌ kompaktní jižní s některými směrovými odbočkami $430 \mathrm{~m}$, severní pinkový pás $390 \mathrm{~m}$.

Právě severní řadu obvalů kř́ízí v polovině jeho JZZ-SVV průběhu téměř kolmo kratší, v severojižním směru po spádnici jdoucí, v délce 160-170 m sledovatelný příčný obvalový tah, tvořený pouze dvěma mohutnými jámami a několika nevýraznými šachticemi; v kombinaci s jižnějším pásmem obvalů vytváŕí typickou trojúhelnou strukturu, výstižně zachycenou již na Wolfskronově náčrtu. Teoreticky by mohlo jít o jámy a světlíky dědičné štoly, zř́izené na severním úpatí areálu v potočním ohybu. Štola by nejkratším směrem, prakticky napřičc podfárala všechny třri pásy dobývek (za takovouto eventualitu interpretace děkuji Josefu Večeřovi). Musela by být ovšem ražena namáhavě „přes kámen“, kolmo na předpokládanou směrovou texturu horniny a žilných pásem, s velkým nákladem a jen malým postupem (cf. Kořan 1955, 125; 1974, 218; Günther 2001, 131-133; Pierre
2011). Obě nejvýraznější jámy na této př́ičné obvalové linii nadto nemají charakter pouhých světlíků nebo větracích šachtic, jde naopak o jedny z nejmohutnějších reliktů báňské činnosti na lokalitě vůbec. Patrně se zde tedy jednalo o hlubinné dobývky na místním odžilku se dvěma ústředními šachtami. Jejich dodatečné napojení a využití později raženou dědičnou štolou přitom ovšem nelze vůbec vyloučit: obdobné řešení bylo ve stř̌edověké horní praxi zcela obvyklé. Vzpomenout je možné kupř́íkladu v Kutné Hoře dědičnou štolu roveňského žilného pásma, jíž i jako světlíky sloužily šachty hned několika starších dolů (Svatý Pavel, Červený lev, Černý lev, Pelikán a další; srov. Bílek 2000c, 17-18). Př́ípadné stopy ústí takto vytýčeného dědičného díla v údolí nad korytem Záskalského potoka nejsou dnes markantně patrné, ověřit nebo vyvrátit tuto variantu odvodnění havírenského důlního areálu může jedině další prospekce.

Patrný výtok důlních vod, signalizující stržené ústí dědičné štoly, lze ale zaznamenat na jiném místě, v potočním úžlabí pod severozápadním zakončením nejsevernějšího z obvalových tahů (Houzar et al. 2000, 129; Doležel, Sadílek 2004, 51, 55, obr. 5: 2). Zřejmě nikoliv náhodou je právě do těchto partií kladena štola František, rozpracovaná (či vyzmáhávaná) roku 1774, kterou ještě o sto let později jako Zumberger-Stollen vyznačil do svého plánu Max von Wolfskron (Wolfskron 1889, tab. V, obr. 1; srov. obr. 3; Polák 1960, 24, 37; Velebil, Kráčmar 2002, 178). Je proto pravděpodobnější, že dědičné dílo k odvodnění západní části nebo i celé hory bylo raženo právě z tohoto nivelačně vưbec nejnižšího místa areálu „lehčí skálou“, „po žíle“, která skýtala současně i těžitelnou rudu, nejprve pod severním pásmem šachet a poté odbočkou či větvením pod další tahy. Výškový rozdíl mezi předpokládaným ústím štoly a nejvýše položenými jámami činí 120 m, teoreticky mohla hlubina dưlních děl na Havírně dosahovat nejméně této úrovně, délka dědičné štoly pak více než $500 \mathrm{~m}$.

Určitější údaje snad přinese další prospekce, hloubkový dosah a rozlehlost středověkých horních prací však obecně nelze podceňovat. Extrémní hloubky a objemy středověkých stařin v českých zemích exaktně prokázaly novodobé ověřovací otvírky např́iklad na Grejfském žilném pásmu v Kutné Hoře či na rotlevském úseku a Šišléřské žíle Šlojířského žilného pásma v Jílovém (Bílek 2000b, 18-19; Morávek, Litochleb 2002, 17-18, 39, 103-105). Stejně tak moderní montánně archeologické výzkumy doložily překvapivě rozsáhlé a do hloubky mnoha desítek metrů jdoucí úvodní partie dobývek na více stř̌edověkých či časně novověkých důlních ceších, a to i na málo významných. Jmenovat je namátkou možné kupř́ikladu více lokalit ve Francii, v porýnském Siegerlandu Altenberg a báňské dílo Alte Mann u Kreuztal-Burgholdinghausenu, ve Schwarzwaldu šachtu Svatých tří králů u Freudenstadtu, systém hlubinných prací v revíru Sankt Ulrich-Birkenberg nebo stařiny na Riestergangu v Sulzburgu, v Sasku pak doly v Dippoldiswalde a Niederpöbel. ${ }^{5}$ Neméně výmluvné jsou v tomto ohledu i dosud př́stupné středověké části dolů na dlouhodobě až do nejnovější doby exploatovaných ložiscích, v českých zemích zejména díla zlatohorského rudního revíru (např. Novotný, Zimák 2003, 13-33, obr. P 19, 22-41, 58-61; Hruban et al. 2011, 112-113, 130-143, obr. 126-144).

V této souvislosti lze jen orientačně připomenout, že za plnoprávnou štolu dědičnou byla podle horního zákoníku Václava II. i podle německé verze jihlavského práva $\mathrm{z} 1$. poloviny 14 . věku

Obr. 8. Středověký areál těžby stříbra Havírna u Štěpánova nad Svratkou. Vrstevnicové znázornění digitálního modelu terénu (DTM) jako základní výstup detailního pozemního laserového skenování lokality v letech 2017-2019. Základní vrstevnice vykresleny s intervalem 0,2 m, hlavní vrstevnice s intervalem $5 \mathrm{~m}$. Autor M. Tejkal. Fig. 8. Medieval silver mining area Havírna near Štěpánov nad Svratkou. Contour representation of a digital terrain model (DTM) as a basic output of detailed ground-based laser scanning of the site in the years 2017-2019. Basic contours drawn with an interval of $0.2 \mathrm{~m}$, main contours with an interval of $5 \mathrm{~m}$. Author M. Tejkal. 


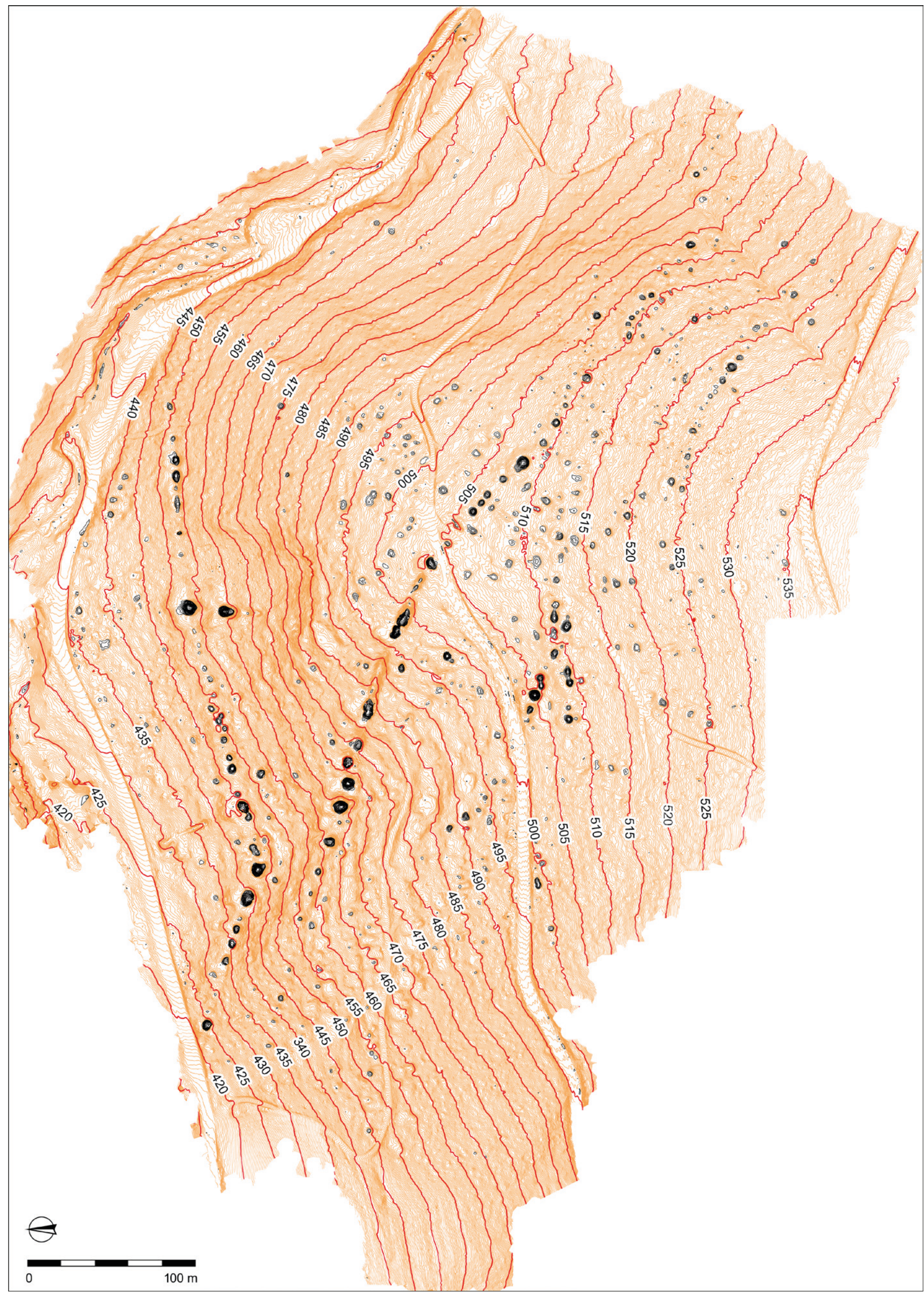




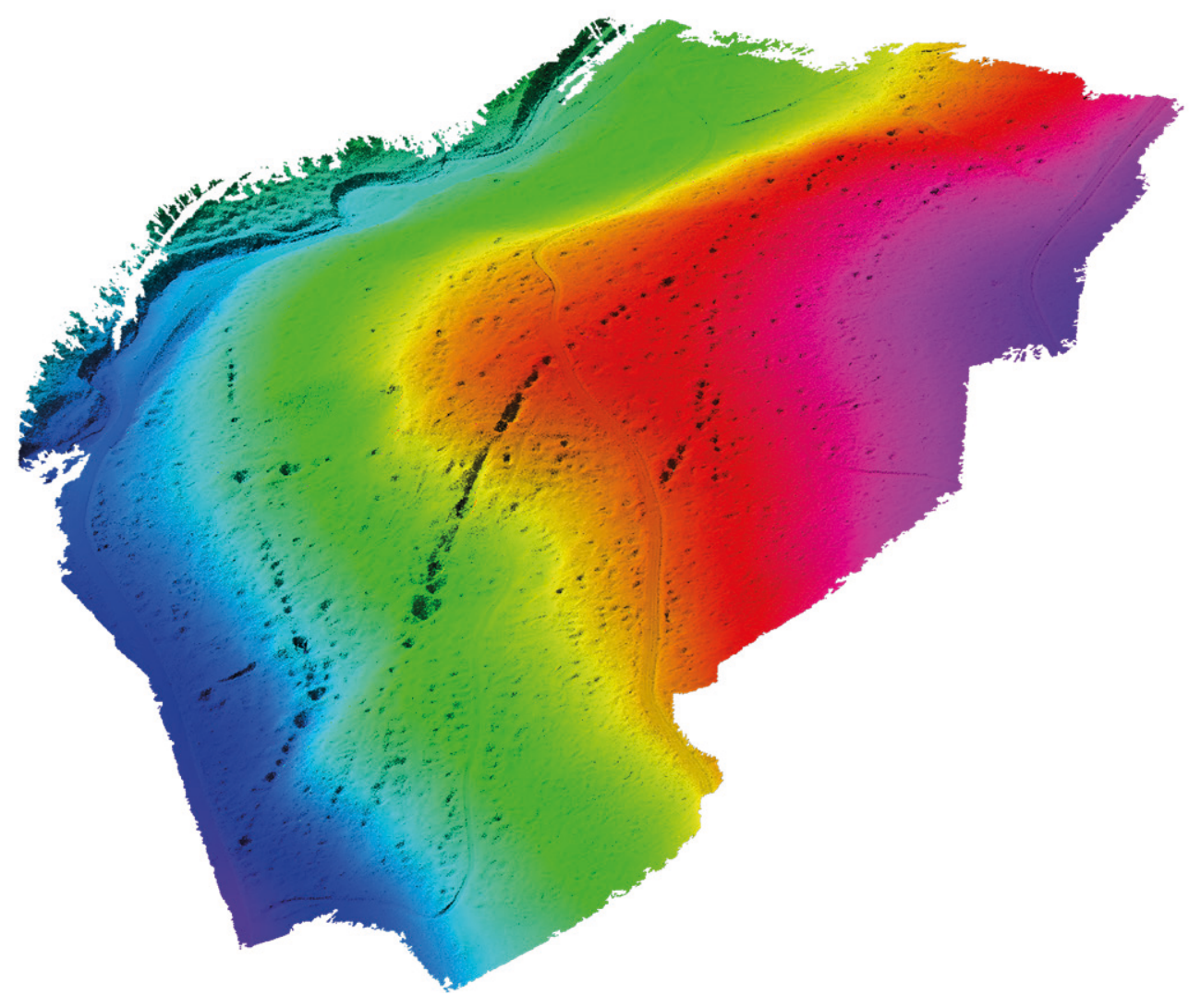

Obr. 9. Středověký areál těžby stř́bra Havírna u Štěpánova nad Svratkou. Detailní pozemní laserové skenování prostoru dobývek v letech 2017-2019. Digitální model terénu v 3D stínovaném modelu - perspektivní pohled od západu. Autor M. Tejkal.

Fig. 9. Medieval silver mining area Havírna near Štěpánov nad Svratkou. Detailed ground-based laser scanning of the mining area in the years 2017-2019. Digital terrain model in $3 D$ shaded model - perspective view from the west. Author M. Tejkal. prohlášena ta štola, jež odvodnila a odvětrala nejméně deset důlních měr, nebo dosáhla hloubky minimálně 1,5 lánu, tedy přibližně 21 m (Zycha 1900b, 20, § 4, odst. 3; 152-153, Lib. II, Cap. 4, § 14; Bílek ed. 2000a, 48, Lib. II, Cap. IV, § 16; srov. Kořan 1974, 218; Vosáhlo 1996, 35). Dobrým příkladem velmi časného, „po žíle“ raženého dědičného díla, které podsedlo a odvedlo vodu $\mathrm{z}$ celé řady dolů, může být dědičná štola na kutnohorském Kuklíku, ústící v Gruntě, jako stolo iuxta vallem ecclesie beate Marie virginis poprvé připomínaná roku 1305. Již tehdy společenství těžařu udělilo na štole koncesi Jindřichovi řečenému Grossus k vybudování nového štolního větvení, které by vysušilo další horní díla (RBM II, 1 212-1 213, č. 2 773). Koncem středověku tak kuklická dědičná štola nabyla podobu velmi složitého systému chodeb, odboček a překopů, s hlavní větví více než $2 \mathrm{~km}$ dlouhou (Kořan 1950, 7, 129-133, tab. XV; Bílek 2000d, 7-12, 19, 28-29).

Jako těžební areál, opuštěný prakticky na počátku 14. století a intaktně dochovaný bez jakýchkoliv podstatnějších mladších antropogenních zásahů, disponuje štěpánovská Havírna vysokým potenciálem informací pro studium dosud ne vždy uspokojivě objasněných otázek spojených s organizací, právním režimem a vyměřováním středověkých horních děl i velikostí důlních měr v českých zemích. Směrodatné údaje poskytuje staré horní právo, platné v českém státě 13. až počátku 16. století, ve všech svých dnes známých písemných kodifikacích: jde zejména o tři hlavní redakce jihlavského horního práva, brodské městské a horní privilegium z roku 1278 i Ius regale montanorum krále Václava II. z počátku 14. století (jednotlivé základní edice: CDB IV.1, 290-328, č. 177; V.2, 596-610, č. 873; Zycha 1900b, 1-297; Bretholz 1903, 205-281; Hoffmann ed. 1959, 31-63; Bílek ed. 2000a, 17-84). Neocenitelným zdrojem poznatků jsou i v tomto ohledu také dotazy vznesené na jihlavský vrchní horní soud zejména z Kutné Hory a jím následně vynesené výroky, stejně jako dochované formulářové listinné doklady o jednotlivých vyměřených dolech, opět především kutnohorských (Zycha 1900b, o rozměření důlních polí zvl. 303, 314-321, 325-326, 378-386, 398-417, č. 3, 10, 11, 16, 51, 53, 55-59; Bretholz 1903, 43-44, 59-61, č. III, VIII, IX; Tadra ed. 1882, 342-348, 350-353, 409-411, č. 11-16, 19-21, 88, 89).

Přesto výklad středověkých právních normativů vyžaduje, co se týče způsobu vytyčování horních měr, další podrobné studium: jde o vyměřování důlních lánů v základní horní míře, způsob a dobu přiměřování lánů královských, městských a panských po jejích obou stranách, stejně jako o celkovou délku standardně vyměřeného dolového pole, ale i dimenze prospekčních prací a velikost prvotních nálezných polí. ${ }^{6}$ Dosavadní interpretační pokusy, vycházející z aplikací příslušných rozměrových modelů na důlních dílech zejména v Jesenících, ale i na Českomoravské vrchovině, v Krušnohoří a jiných evropských revírech, totiž nabízejí dosud výsledky velmi disparátní a nejednoznačné, ovlivněné zřejmě konkrétní historickou situací, regionálními poměry a diferencovanými časovými fázemi dolování, stejně jako rozdílným způsobem „čtení“ primárních písemných pramenů.?

Je zcela zřejmé, že spolehlivější výchozí údaje pro podrobnější analýzu možného vytyčení horních měr na Havírně poskytne teprve plánovaný detailní metrický rozbor dochovaných těžebních děl po jejich primární funkční interpretaci. Obecně předpokládané základní důlní míře o délce sedmi a šířce čtyř a půl lánu (přibližně $98 \times 63$ m) může odpovídat více obvalových seskupení na jednotlivých tazích, kupř́íkladu série jam ve východním zakončení nejsevernějšího ze tří hlavních těžených pásem (srov. obr. 8, 16). Úvahu o přiměřování dalších lánů (královských, městských, panských) na štěpánovské Havírně komplikuje ovšem nejistota o příslušnosti štěpánovského rudního revíru ke konkrétní stolici horního práva před rokem 1297, kdy král Václav II. přiř̌knul horní právo na zdejších dolech - a tedy i pravomoc vytyčovat k základním horním mírám vlastní městské lány - městu Brnu (CDM V, 61-62, č. 65; Flodr 1990, 403-404, č. VII; srov. i Doležel, Sadílek 


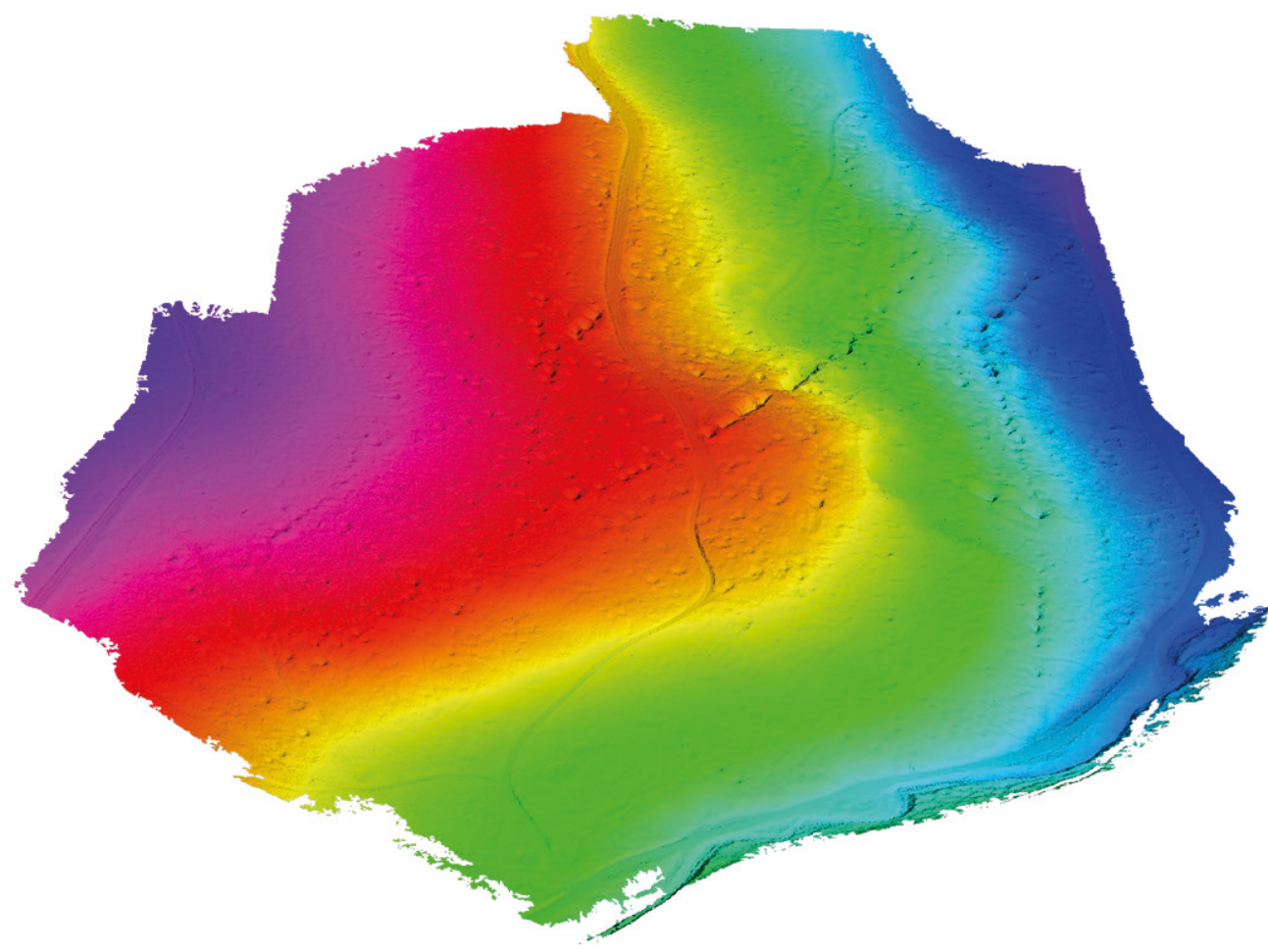

Obr. 10. Středověký areál těžby stříbra Havírna u Štěpánova nad Svratkou. Detailní pozemní laserové skenování oblasti exploatace vletech 2017-2019. Digitální model terénu v3D stínovaném modelu - perspektivní pohled od severovýchodu. Autor M. Tejkal. Fig. 10. Medieval silver mining area Havírna near Štěpánov nad Svratkou. Detailed ground-based laser scanning of the exploitation area in the years 2017-2019. Digital terrain model in 3D shaded model - perspective view from the north-east. Author M. Tejkal.

2004, 115-116, př́loha I, č. 2). Prerogativy královského fisku nad těžbou stř́ibra v revíru deklaroval již v polovině 13 . století ve svém mandátu král Václav I. (CDB IV.1, 488-489, č. 293; Doležel, Sadílek 2004, 77, 114-115, obr. 25, př́loha I, č. 1). Lze proto již v tomto období, stejně jako později, kalkulovat ve zdejších „měřených horách“ s královskými lány. Od počátku nebyly zřejmě zpochybněny ani nároky pozemkové vrchnosti na příslušné „panské “horní lány, at již to byli páni z Medlova či klášter doubravnických augustiniánek. O př́mém angažmá brněnských měštanů na exploataci drahých kovů na Štěpánovsku pak hovoří již krátce před rokem 1253 zmíněný Václavův mandát. Králův zmocněnec, veverský purkrabí Ratibor, tehdy sice měl nejmenovanou „stř́íbrnou horu“ v revíru z držení Brňanů navrátit zpět do vlastnictví kláštera, setrvalé aktivity brněnských patricijů na důlních dílech v regionu jsou však prokázány. Otázka působnosti některé městské obce při horní správě děl štěpánovského rudního okrsku před rokem 1297 tak zůstává otevřená, vedle Brna a Jihlavy připadají do úvahy i jiné alternativy, včetně právní exempce.

Klasické „plné“ horní míře o třinácti lánech, včetně přidaných lánů královských, panských a městských, o přibližné celkové výměře $182 \times 63 \mathrm{~m}$ by se mohlo blížit hned několik skupinových struktur exploatačních prací v areálu Havírny. Jde kupříkladu o šachty na jihovýchodním konci horního, nejjižnějšího těžebního pásma, kde se ke třem ústředním jámám, zaraženým snad na nálezném poli o velikosti dvou lánů (v délce 28-30 m, viz následující výklad) řadí v linii další šachty (obr. 8, 17). Nejasné indicie obdobného rozvržení lze sledovat i v některých dalších partiích důlního území, teoreticky připadá vzhledem k celkovému rozsahu zachovaných starých báňských děl na Havírně do úvahy vytýčení šesti až sedmi úplných horních měr.

Na prvý pohled nejmarkantnějším prvkem jsou tu ale koncentrované trojice šachet, pravidelně rozmístěných v délce okolo $20 \mathrm{~m}$ (17-22 m; snad až šest obdobných seskupení v rámci lokality; srov. obr. 8, 18). Tyto sestavy mohou odpovídat ochrannému náleznému poli o výměře dvou lánů, kdy se jak podle nejstaršího jihlavského a brodského práva, tak Ius regale montanorum kolem nálezné jámy vyměřilo ochranné pásmo po jednom lánu na obě strany, tedy v celkové délce asi $28 \mathrm{~m}$; tento normativní postup pak byl dle sentencí jihlavských horních přísežných obecně zachováván i po celé 14. a počátek 15. století (CDB IV.1, 327, č. 177, čl. X; V.2, 603, 609, č. 873, čl. 81; Zycha 1900b, 7, čl. VIII, § 16; 122-123, Lib. II, Cap. 1, §9, 10; 299-302, 312-313, č. 1, 2, 7; Bretholz 1903, 229; Bílek ed. 2000a, 40-41, Lib. II, Cap. I, § 8, 9). Termín „průzkumné pole“, obvykle pro tuto horní míru užívaný v odborné literatuře (např. Večeřa 2009b, 5-7, 10-16, obr. 1, 3-8; 2013, 45-46, 48-58, obr. 2, 5-8, 10; Večeřa, Večeřová 2010, 51, 57, obr. 74, 85; Derner et al. 2019, 938), nepovažuji přitom za př́liš vhodný. Její vyměření bylo v př́slušných dobových ustanoveních horního práva totiž jasně vázáno nikoliv na prospekci, ale již na samotný nález zrudnění. Zaražením dalších dvou jam v těchto lánech, po jedné po obou stranách jámy nálezné, by tak primární nálezce zajištoval fakticky takto jemu přidělené horní míry před ostatními hledači, a zároveň pro případ budoucího vyměření standardní horní míry o sedmi lánech splňoval podmínku mladších verzí jihlavského horního práva i konstitucí Václava II. o minimálním předepsaném počtu tří šachet $\mathrm{v}$ takovéto míře (CDB IV.1, 325, č. 177, čl. IIa; Zycha 1900b, 10, čl. I, § 10; 27, § 14, odst. 2; 172-173, Lib. III, Cap. 1, § 9; Bretholz 1903, 243; Bílek ed. 2000a, 53, Lib. III, Cap. I, §9).

Vyměřené dvoulánové primární nálezné pole tak mohlo mít obvykle podobu míry o délce $28-30 \mathrm{~m}$ a šíri 14 m, otevřené vždy trojicí šachet ve vzájemných distancích přibližně $10 \mathrm{~m}$, po započtení vystrojení šachet tedy ve vzdálenosti dvou láter. Hypotézu o aplikaci takto uspořádaného nálezného pole by pro štěpánovský rudní revír vedle opakujících se výskytů na vlastní Havírně mohly podporovat i další báňské lokality v blízkém okolí. Zcela 
identické rozměry i konfiguraci vykazuje nově evidovaná stařina v lesní trati Pod Ždánicemi (k. ú. Švařec), 250 m SSV od Havírny, charakteru pokročilejší, rozfárané prospekční otvírky (Doležel v tisku). Velmi blízkou sestavu tř́i výrazných šachet v celkové délce $22 \mathrm{~m}$ lze sledovat rovněž v severním závěru pásma obvalů po středověké těžbě stříbra $\mathrm{v}$ Pavelkově lese u Horního Čepí. Charakteristická trojice jam, zaražených v pásu $21 \mathrm{~m}$, stejně tak zahajuje na spodním konci linii jinak očividně prospekčních prací, sledujících směrnou rudní strukturu v jižním úbočí údolí Hodůnky (k. ú. Černovice), naproti štěpánovské Vysoké skále. V podstatě ze dvou trojic šachtic je dále složeno drobnější, velmi dobře dochované báňské dílo východně samoty Hrachovce na katastru Čtyř Dvorů, horní z nich o délce 29 m, spodní koncentrovanější o délce 21,5 m. Tři jámové dobývky, soustředěné v úseku $17 \mathrm{~m}$, tvoří rovněž jádro pásma obvalů nad Korouženskou štolou ( $k$. ú. Koroužné), zatímco důlní cech ve východní části stařin v trati Na Bukovské (k. ú. Borovec) sestává opět $\mathrm{v}$ podstatě ze dvou trojic šachet, zaražených $\mathrm{v}$ distancích $25,5 \mathrm{~m}$, resp. $24 \mathrm{~m}$. Nutné ale bude zohlednit i zde možnost více fází středověkých či časně novověkých důlních prací na kutištích. ${ }^{8}$

Cenné poznatky slibuje přinést detailní rozbor dokumentovaných důlních prací na Havírně pro objasnění samotného vyhledávání a prospekce rudních akumulací ve středověku (inspirativně Vosáhlo 1996, 29-37; nové informace z Vysočiny shrnul Hrubý 2019, 80). Pozornost zasluhují zejména izolované šachtice, rozptýlené plošně mimo stěžejní exploatované struktury jak
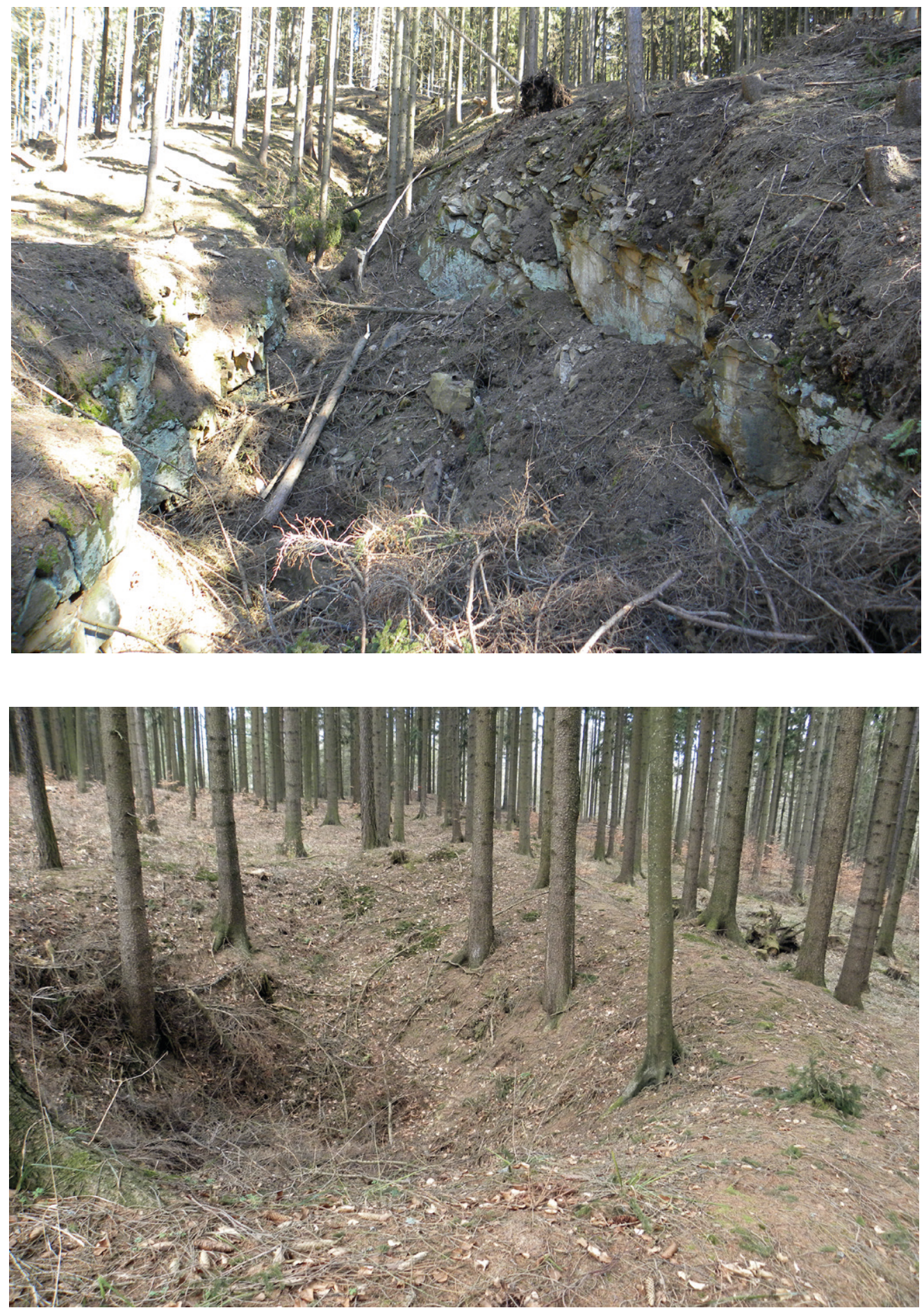

Obr. 11. Středověký areál těžby stř́bra Havírna u Štěpánova nad Svratkou. Povrchový výrub v severnější polovině středního pásu obvalů, pod lesní svážnicí. Foto J. Doležel, duben 2019

Fig. 11. Medieval silver mining area Havírna near Štěpánov nad Svratkou. Worked veins in the northern half of the middle strip of shafts, under the forest road. Photo by J. Doležel, April 2019.
Obr. 12. Středověký areál těžby stř́bra Havírna u Štěpánova nad Svratkou. Šachta s výrazným odvalem v západní části nejjižnější linie dobývek, nad lesní svážnicí. Foto J. Doležel, březen 2019.

Fig. 12. Medieval silver mining area Havírna near Štěpánov nad Svratkou. A shaft with a significant spoil heap in the western part of the southernmost line of the mines, above the forest road. Photo by J. Doležel, March 2019. 
v pozvolnější jižní, tak srázné severní polovině lokality, stejně jako na severním okraji, při potočním úžlabí. Markantní a velmi dobře zachovaný je tento druh otvírek zejména v jihovýchodním zakončení důlního areálu (obr. 8, 19). V silně svažitém terénu zde zřejmě $\mathrm{v}$ některých případech šachtice doprovází krátká hledací štolka níže ve svahu. Právě drobnější započaté, dále podstatněji nehloubené prospekční šachtice mohou na Havírně také uchovávat určitější stopy původní úpravy ohlubně, a v kamenitém podloží i obrysy samotného šachetního ústí: patří k nim například šachtice ve středním úseku severního obvalového tahu, s ohlubněmi zřejmě fixovanými zídkami z nasucho kladených kamenů, $\mathrm{s}$ dosud kvadratickým, většinou lehce podélným půdorysem od $2,1 \times 2,6 \mathrm{~m}$ do $5,1 \times 4,4 \mathrm{~m}$.

\subsubsection{Problematika lokalizace úpravních a hutních provozů a využití vodní energie}

Samostatné téma představuje pro štěpánovskou Havírnu situování prostorů primární úpravy vydobytých rud, následných přípravných metalurgických operací i vlastního hutnění získaných koncentrátů až po výsledný produkt. Bylo už upozorněno na četný výskyt větších teras ve svažitém terénu lokality, v některých případech přepažených nasucho kladenými kamennými zídkami (obr. 20, 21; srov. Doležel, Sadílek 2004, 51, 55, 60, 72, obr. 5, $13,14)$. Právě na těchto rozsáhlejších terasách byly zjištěny někdy až masivní koncentrace dřevěného uhlí a strusek po hutnění železných i polymetalických rud (podrobněji Doležel, Sadílek 2004, 68-70, 118-119, příloha II; též např. Stránský et al. 2013a, 42-47,

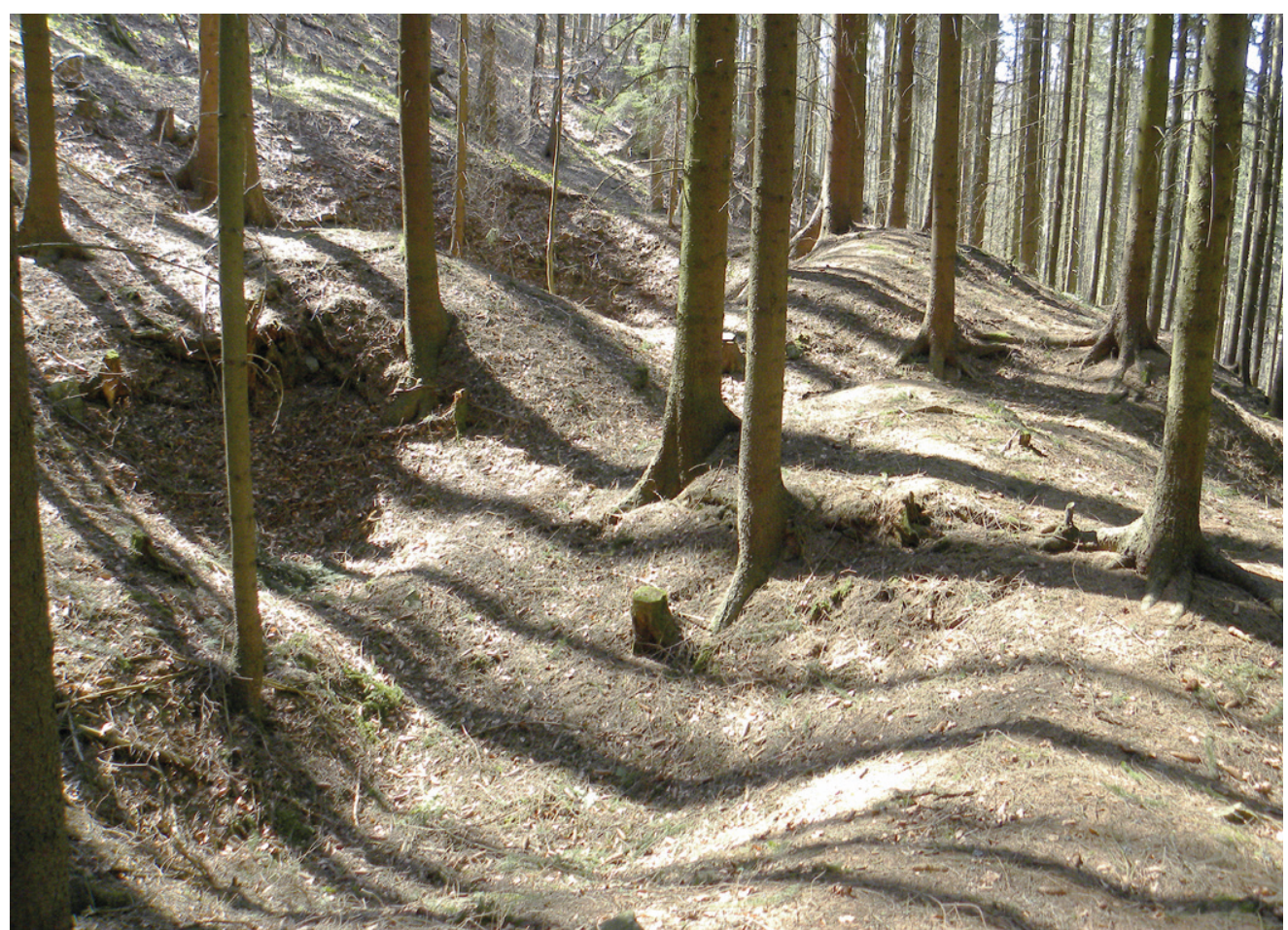

Obr. 13. Středověký areál těžby stříbra Havírna u Štěpánova nad Svratkou. Souvislé pásmo šachet vzápadní partii severního obvalového pásma, v místě jeho lomu kseverozápadu. Foto J. Doležel, duben 2019.

Fig. 13. Medieval silver mining area Havírna near Štěpánov nad Svratkou. A continuous zone of shafts in the western part of the northern line of the mines, at its quarry to the north-west. Photo by J. Doležel, April 2019.

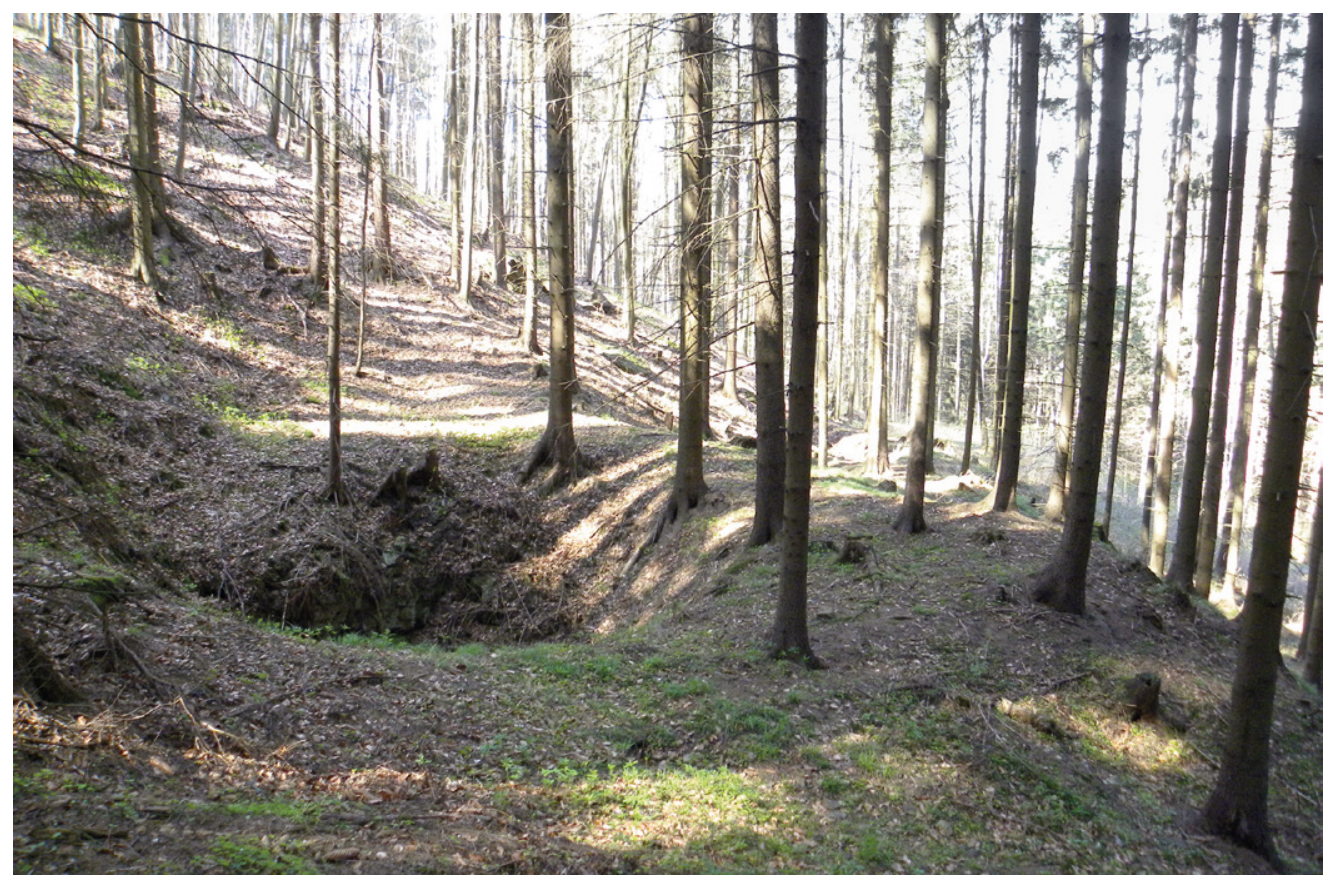

Obr. 14. Středověký areál těžby stř́bra Havírna u Štěpánova nad Svratkou. Velká šachta s odvalem a obslužným prostorem v západní části severní řady dobývek, těsně za zlomem kseverozápadu. Foto J. Doležel, duben 2017. Fig. 14. Medieval silver mining area Havírna near Štěpánov nad Svratkou. A large shaft with a spoil heap and service area in the western part of the northern row of shafts, just behind the break to the north-west. Photo by J. Doležel, April 2017. 


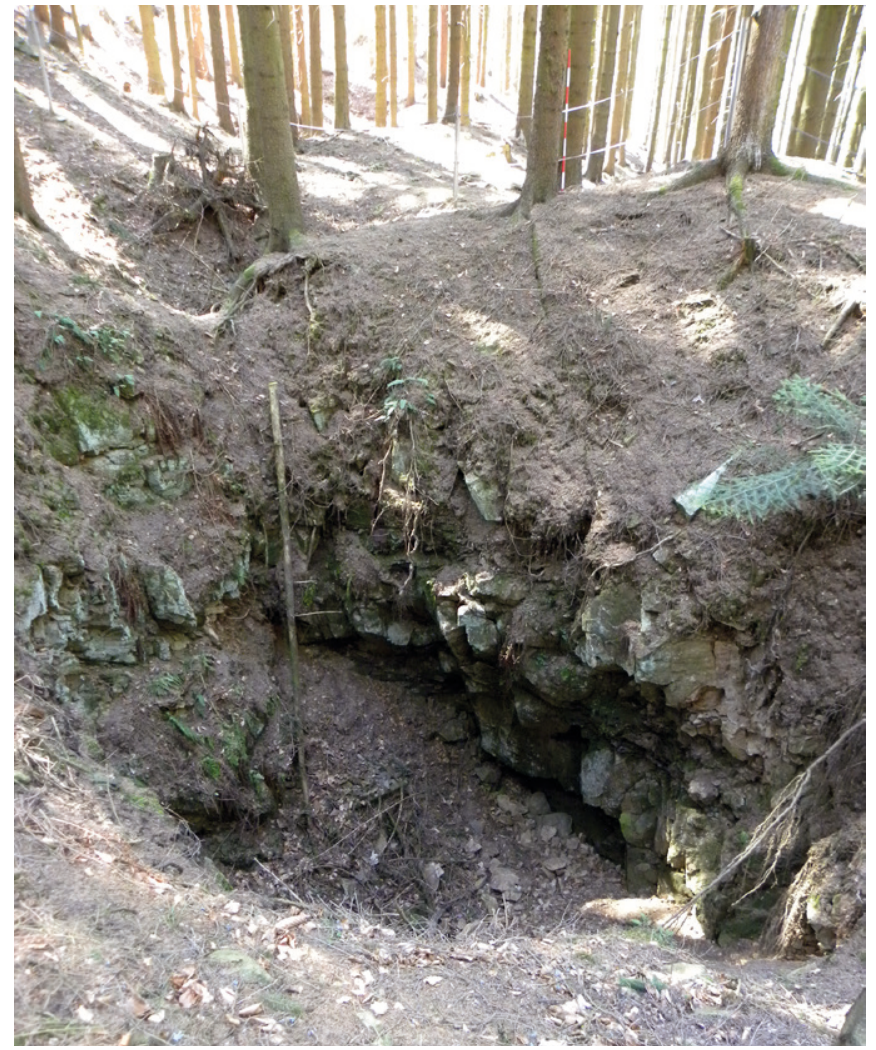

Obr. 15. Středověký areál těžby stříbra Havírna u Štěpánova nad Svratkou. Dosud otevřené důlní dílo ve střední třetině severního obvalového tahu, od severu nafárané prospekční štolou Václav. Foto J. Doležel, duben 2019.

Fig. 15. Medieval silver mining area Havírna near Štěpánov nad Svratkou. A mine which has been opened until now in the middle third of the northern line of mining remains, excavated from the north by the Václav prospecting adit. Photo by J. Doležel, April 2019. obr. 11, 12, tab. III). Ve svahu jihozápadní ćásti komplexu lze při horním zářezu jedné z těchto plošin navíc zaznamenat řadu nejméně čtyř až pěti větších konvexních útvarů; jednou z možných eventualit je interpretace těchto reliktů jako série destruovaných pyrometalurgických objektů, pro snazší obsluhu výhodně situovaných při svahovém zářezu (obr. 22, 23). Menší konvexní destrukce s vysokým podílem kamene v jádře i na povrchu, ztotožnitelné snad se zbytky pecí či otopných zařízení, se pak vyskytují na více místech areálu, kupříkladu při sídelních terasách na severozápadním okraji. Vedle úpravních či př́imo hutních zařízení zde mohlo jít samozřejmě o výhně, pece či ohniště jiných funkcí, včetně topeništ v obytných či obecně sídlištních stavbách; bližší identifikaci a typovou i funkční charakteristiku jak metalurgických, tak dalších pyrotechnologických a otopných objektů na lokalitě mohou přinést jedině cílené archeologické odkryvy či nedestruktivní prospekce (geomagnetika, geochemie apod.).

Provozně výhodné, ve svažitých terénech pak prrímo nutné umístění úpravních a hutních provozů na větších uměle upravených terasách bylo ve středověkých báňských areálech zcela obvyklým řešením. Stačí vzpomenout čelními kamennými zídkami opatřené dílenské terasy v severozápadní partii horních stařin na saském Treppenhaueru, obdobně uzpůsobená pracovišsě na lokalitě Zellerfeld v Harzu, kovářské a úpravní dílny v důlních komplexech Birkenberg, Süßenbrunn či Todtnauberg ve Schwarzwaldu. Plošiny s pozůstatky hutnění byly dokumentovány na Bastenbergu v porýnském Siegerlandu a v Malachovské dolině na horním Pohroní, výraznou terasu zaujala stoupovna cechu sv. Kryštofa na jihotyrolském Schneebergu (Zimmermann 1993, 206-209, 213-218, obr. 3, 4, 6, 9-12; Steuer, Goldenberg 2002, 408-409, obr. 7; Alper 2003, 49-172, 358-380, plánové př́llohy; Schwabenicky 2009, 78-86; 2011, 13-14, obr. 16; Holdermann 2011, 62-67, obr. 4, 9, 10; Strassburger 2012, 34, obr. 4; Kvietok 2014, 3).

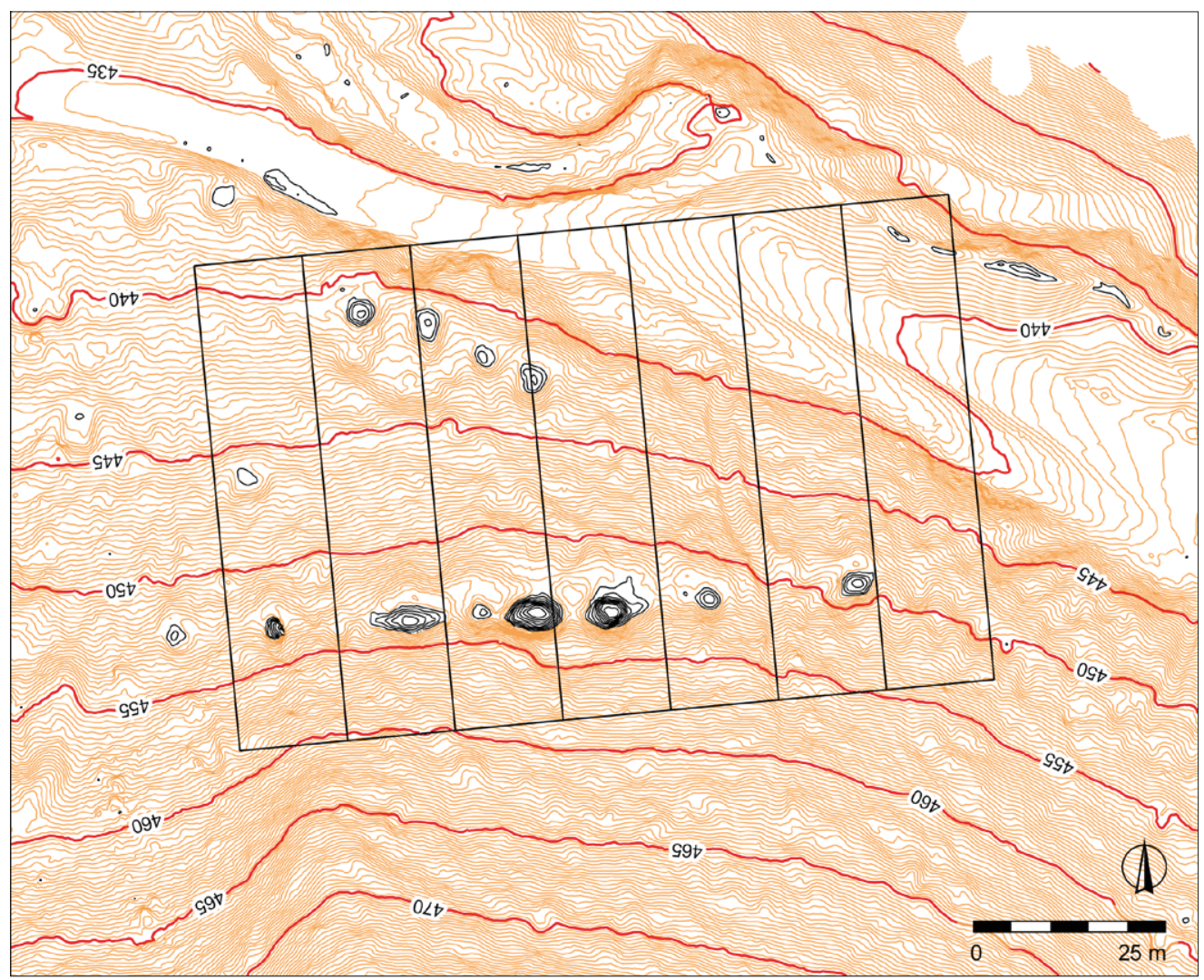

Obr. 16. Středověký areál těžby stř́bra Havírna u Štěpánova nad Svratkou. Projekce bazální sedmilánové důlní míry podle českého horního práva do skupiny šachet ve východním závěru severní linie obvalů. Vrstevnicové znázornění digitálního modelu terénu (2017-2019), autor M. Tejkal, návrh projekce J. Doležel. Fig. 16. Medieval silver mining area Havírna near Štěpánov nad Svratkou. Projection of the basal seven-field mining claim according to Czech mining law into a group of shafts at the eastern end of the northern line of mining remains. Contour representation of a digital terrain model (2017-2019), author M. Tejkal, projection design J. Doležel. 


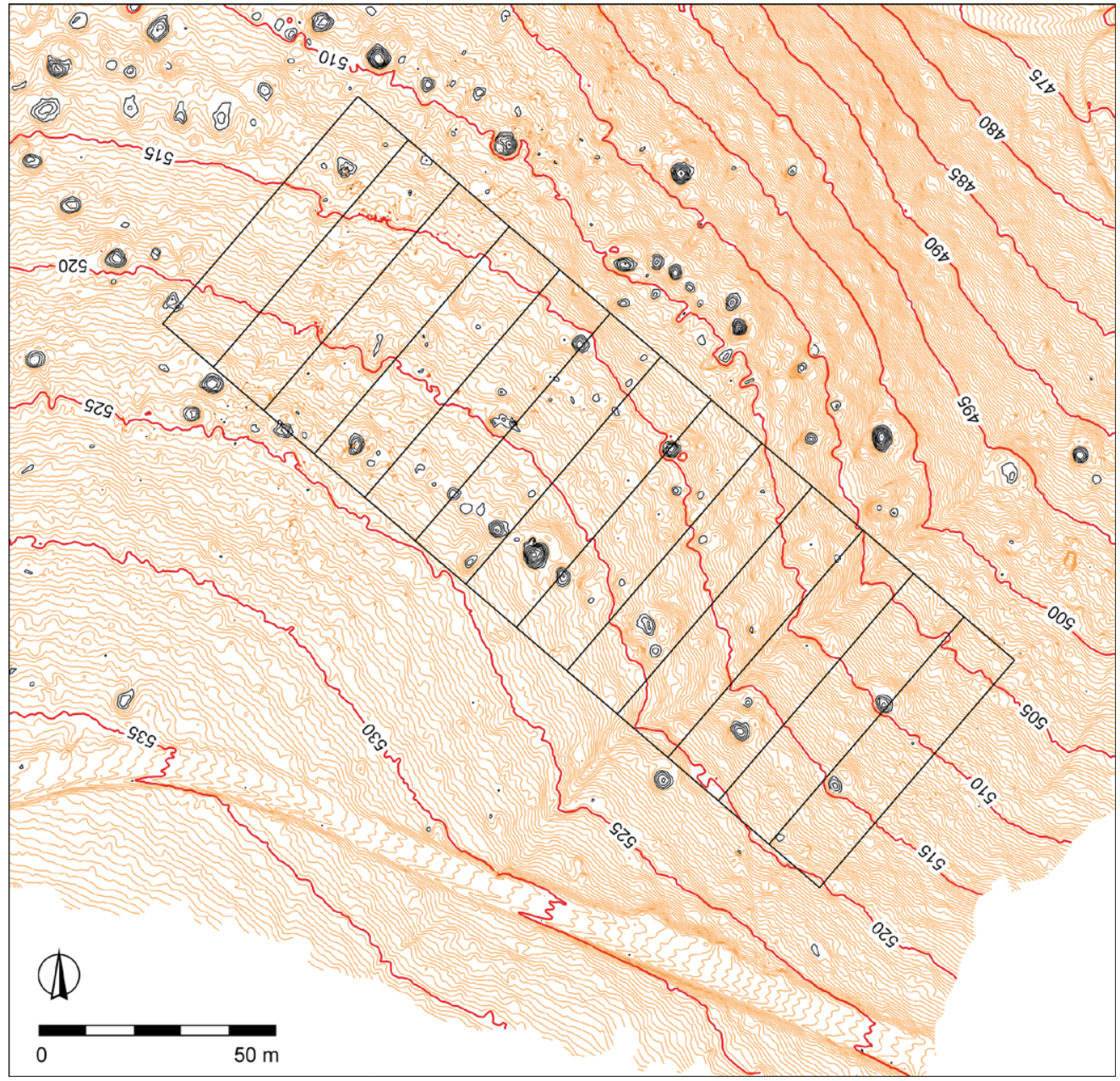

Obr. 17. Středověký areál těžby stř́bra Havírna u Stěpánova nad Svratkou. Průmět plné důlní míry otřinácti lánech do zachovaných šachtic ve východním zakončení jižního pásma důlních prací.

Vrstevnicové znázornění digitálního modelu terénu (2017-2019), autor M. Tejkal, návrh znázornění J. Doležel. Fig. 17. Medieval silver mining area Havírna near Štěpánov nad Svratkou. Projection of a full mining claim of thirteen fields into preserved shafts in the eastern end of the southern zone of mine workings. Contour representation in a digital terrain model (2017-2019), author M. Tejkal, design representation J. Doležel.

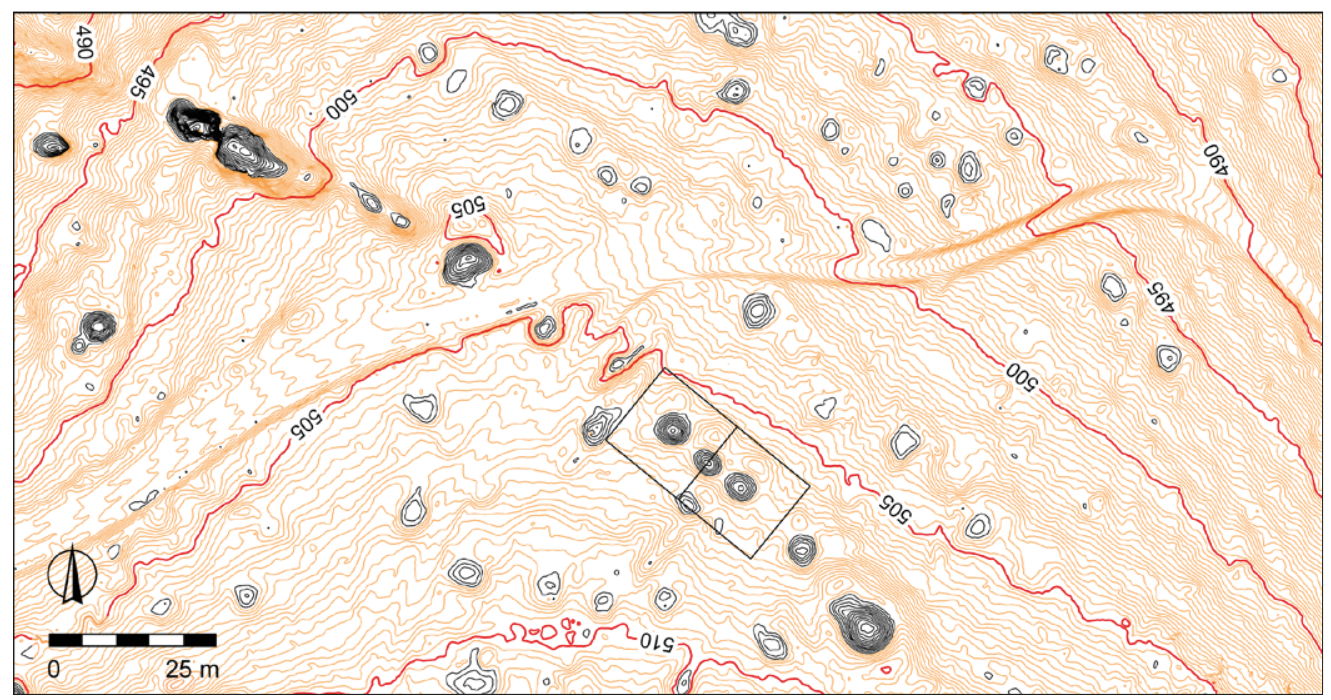

Obr. 18. Středověký areál těžby stříbra Havírna u Štěpánova nad Svratkou. Trojice šachtic v centrálním úseku středního obvalového tahu. Teoretická projekce ochranného důlního pole o dvou lánech, vyměřených po obou stranách nálezné jámy, s dalšími dvěmi šachtami v obou lánech. Vrstevnicové znázornění digitálního modelu terénu (2017-2019), autor M. Tejkal, návrh průmětu J. Doležel.

Fig. 18. Medieval silver mining area Havírna near Štěpánov nad Svratkou. A trio of shafts in the central section of the middle line of mining remains. Theoretical projection of a protective mining field with two fields, measured on both sides of the found pit, with two other shafts in both fields. Contour representation in a digital terrain model (2017-2019), author M. Tejkal, projection design J. Doležel.

Obecným problémem na štěpánovské Havírně mohl být nedostatek vody, mimo jiné i velmi cenného zdroje energie při primární úpravě vytěžených rud, zejména při jejich stoupování, rozemílání v rudních mlýnech a následné gravitační separaci (souhrnně $\mathrm{k}$ využití vody středověkým hornictvím např. Stromer 1984; k úpravnictví klasicky Agricola 1556, 208-284; Ježek, Hummel transl. et. eds. 1933, 231-303; přehledně s využitím nových poznatků archeologie Hrubý 2019, 92-112). Táhlé, ve spodních partiích srázné severní svahy Sokolí hory, v jejímž masivu důlní komplex leží, poskytují pouze nevydatná svahová prameniště. Archeologicky zkoumané báňské celky, situované $\mathrm{v}$ terénech $\mathrm{s}$ nedostatečnými přírodními vodními zdroji, kupříkladu na jihlavských Starých Horách, na krušnohorském Kremsigeru, na Štůlách u Humpolce či u Vyskytné na Pelhřimovsku, využívala k praní rud bud' srážkové a prameništní vody, akumulované v malých nádržích, nebo dokonce důlní vody, čerpané ze šachet. Do úpraven pak byly takto shromažd’ované vodní rezervy vedeny soustavou kanálů (srov. Hrubý et al. 2007, 28-32, 


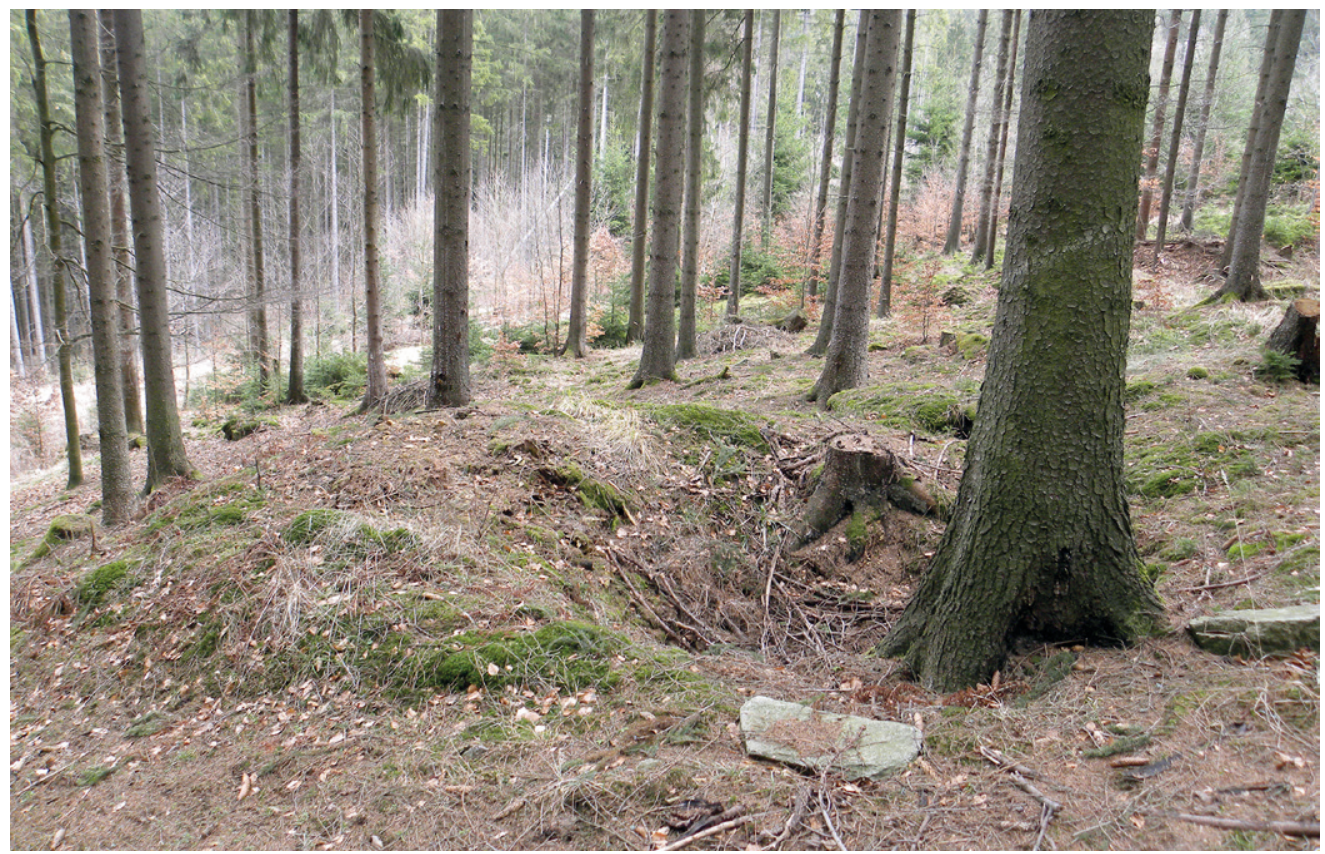

Obr. 19. Středověký areál těžby stř́bra Havírna u Štěpánova nad Svratkou. Prospekční jáma ve svahu najihovýchodním okraji lokality (střední linie obvalů). Foto J. Doležel, březen 2019.

Fig. 19. Medieval silver mining area Havírna near Štěpánov nad Svratkou. Prospecting pit on a slope on the south-eastern edge of the site (middle line of the shafts). Photo by J. Doležel, March 2019.

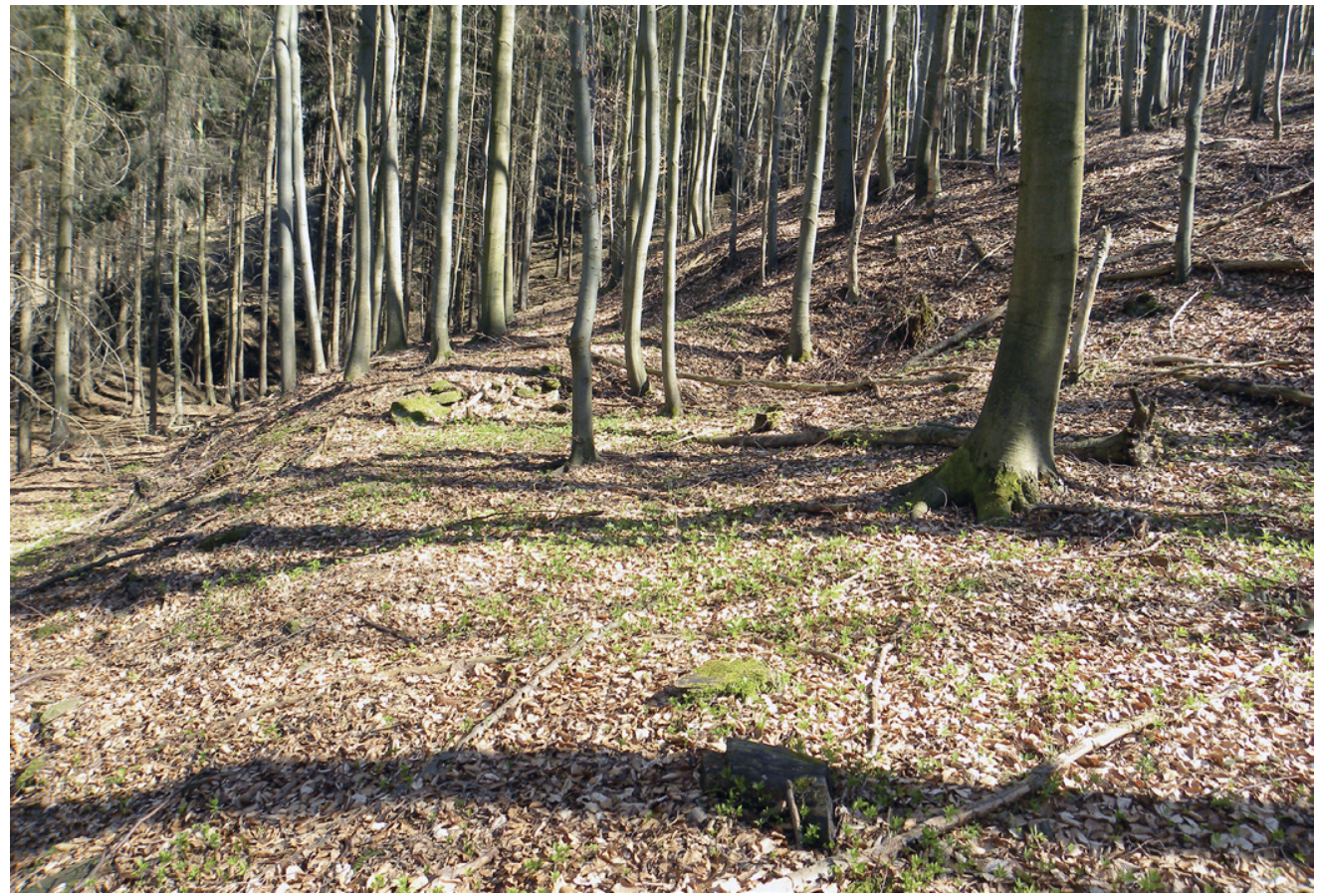

Obr. 20. Středověký areál těžby stř́bra Havírna u Štěpánova nad Svratkou. Východní polovina velké terénní terasy (přibližně $27 \times 7 \mathrm{~m}$ ) ve svahu západní části lokality. Terasa zřetelně např́ič přepažena dělicí, na sucho kladenou kamennu zídkou. Foto J. Doležel, duben 2019.

Fig. 20. Medieval silver mining area Havírna near Štěpánov nad Svratkou. Eastern half of a large terrain terrace (approximately $27 \times 7 \mathrm{~m}$ ) on the slope of the western part of the site. The terrace is clearly crossed by a dry-laid stone dividing wall. Photo by J. Doležel, April 2019.

34, 36, 42, obr. 11, 24, 25; Hrubý 2011, 55, 109-129, obr. 121-138; 2016, 191-192, obr. 11, 12; 2019, 56-57, 69-72, 76-77, 106, 108-109, 171-172, obr. 21, 31-33, 39: E, 78, 119; Derner 2018a, 257-258, 317-318, obr. 184, 249: 5). Ve štěpánovském rudním revíru lze snad zaznamenat umělý přívod vodního zdroje $\mathrm{z}$ výše položených pramenišť na lokalitě Štěpánov - U Vysoké skály (za upozornění na tento antropogenní prvek děkuji Jaroslavu Sadílkovi; cf. např. Houzar et al. 2000, 117, 131, obr. 1, č. 24). Na samotné Havírně ani velmi citlivé reliefní laserové skenování lineární struktury odpovídající rozvodným rýhám nezachytilo. A priori však zejména v ploché jižní polovině areálu nelze vyloučit vedení vody krytými zapuštěnými kanálky, zjistitelnými pouze archeologicky, nebo nadzemními dřevěnými žlaby. Stejně tak ale úpravní provozy ve vyšších partiích těžebního pole mohly zapojit lidskou sílu nebo tažná zvířata, s užitím ručních rudních mlýnů je počítáno kupříkladu na píseckém zlatodole Kometa (Fröhlich 1993; 2019, 619, 625, obr. 2; obecně Fröhlich 2012, 119-122; 2017, 210-214, obr. 7; cf. též Hrubý 2019, 100-104).

Jediným trvalým, relativně stabilním vodním zdrojem byl na štěpánovské Havírně vždy pouze vlastní Záskalský potok v severním okrajovém úžlabí. V obdobných prostorových konfiguracích vodních toků a středověkých důlních cechů prokázaly archeologické odkryvy prakticky vždy rozsáhlé využití takovýchto vodotečí pro úpravu a hutnění exploatovaných rud, dopravovaných na místo i z větších vzdáleností (na Českomoravské vrchovině zejména Cvilínek, Čejkov, Koječín, Utín, ale kupříkladu také Stř́brné Hory, v jesenické oblasti Rýmařov). ${ }^{9}$ Energetický potenciál Záskalského potoka přitom právě v kontaktní pasáži se středověkým těžebním prostorem navyšuje značný spád, dosahující zde na 1,2 km části toku hodnoty $75 \mathrm{~m}$. 
Soustavná prospekce celého toku v širším kontextu středověké exploatace a zpracování polymetalických rud nebyla zatím provedena. Důležité indicie o možných úpravních či hutních provozech $\mathrm{v}$ těsném sepětí $\mathrm{s}$ vodotečí přinesla ovšem šlichová prospekce, realizovaná v letech 2017 a 2018 v rámci pojednávaného projektu Karlem Malým ve zhruba 1,5 km dlouhém úseku Záskalského potoka v nejbližším okolí lokality; v nálezově nejbohatším bodě ji doplnila drobná sondáž. Maximální výskyty strusek z tavení polymetalických rud byly přitom příznačně zaznamenány v korytě přímo při severovýchodním okraji areálu těžby. Kromě teras v rámci samotné lokality tedy také zde nebo v těsnější distanci mohlo probíhat vlastní hutnění či následné operace, hutní strusky využívající (Malý 2020). Analýzy strusek z potočního úžlabí, s neobvykle vysokými až extrémními obsahy olova (7,6-39 hmot. \% Pb) znovu naznačují mimořádný význam Havírny v kontextu dobové exploatace drahých kovů. Indikují zřejmě nestandardní technologické postupy, které zde mohly být aplikovány při tavbě ušlechtilých, bohatých rud stř́ibra. Pokročilé úrovni metalurgie na lokalitě nasvědčuje rovněž materiálové složení některých kovových slitků, nalezených přímo v důlním komplexu, odpovídající tzv. černé mědi jako vedlejšímu produktu po hutnění velmi kvalitního galenit-freibergitového koncentrátu (podrobněji opět Malý 2020).
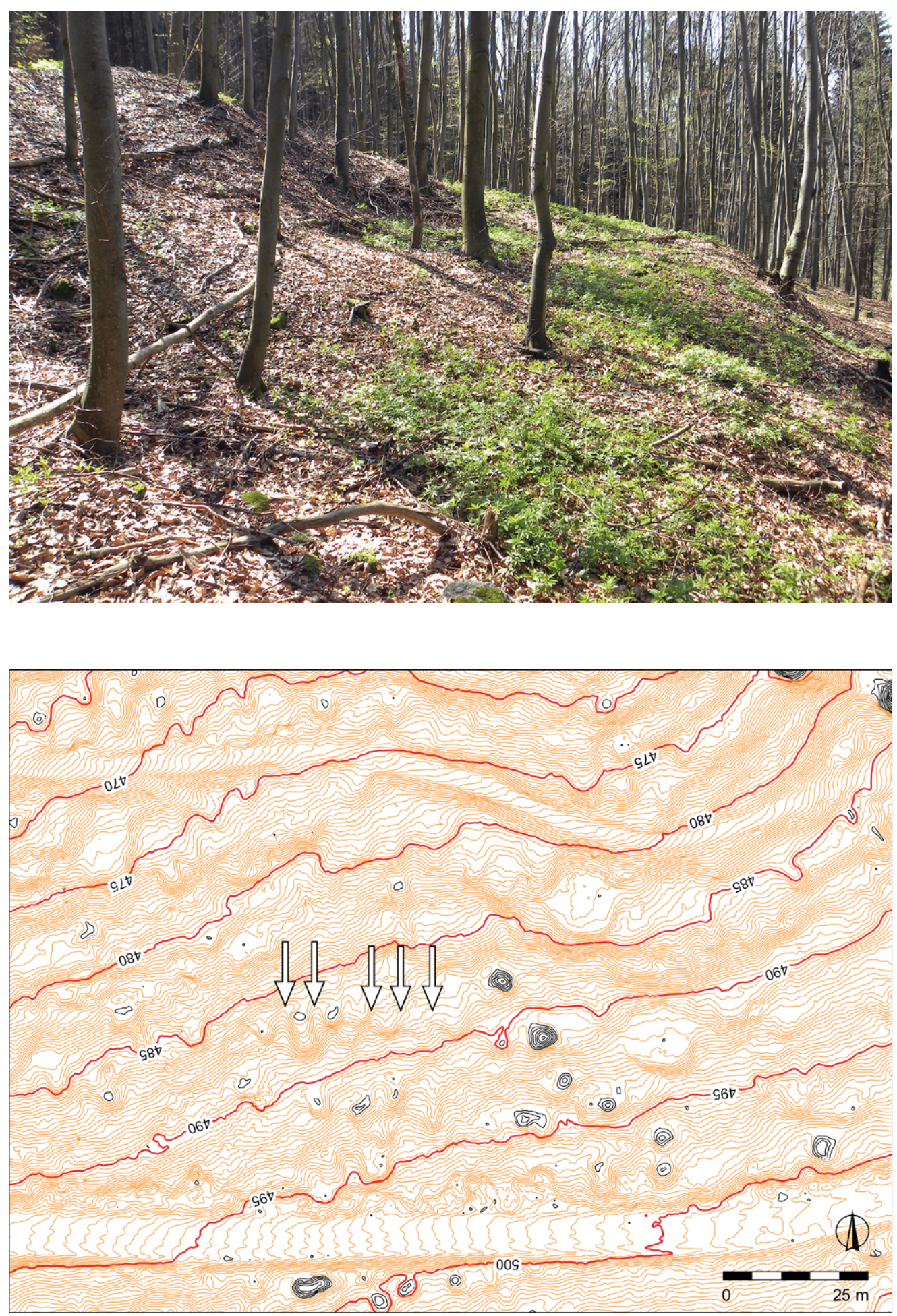

Obr. 21. Středověký areál těžby stříbra Havírna u Štěpánova nad Svratkou. Západní partie téže terasy jako na obr. 20. Foto J. Doležel, duben 2017.

Fig. 21. Medieval silver mining area Havírna near Štěpánov nad Svratkou. The western part of the same terrace as in Fig. 20. Photo by J. Doležel, April 2017.
Obr. 22. Stř̌edověký areál těžby stříbra Havírna u Štěpánova nad Svratkou. Zdvojená terasa a okolní terénní útvary v jihozápadním dílu lokality. Při jižním, horním okraji terasy nápadná skupina konvexních reliktů (vyznačena šipkami). Výřez vrstevnicového znázornění digitálního modelu terénu (2017-2019), autor M. Tejkal.

Fig. 22. Medieval silver mining area Havírna near Štěpánov nad Svratkou. Doubled terrace and surrounding terrain formations in the southwestern part of the site. Astriking group of convex relics on the southern, upper edge of the terrace (marked by arrows). A cut-out of the contour representation in a digital terrain model (2017-2019), author M. Tejkal. 


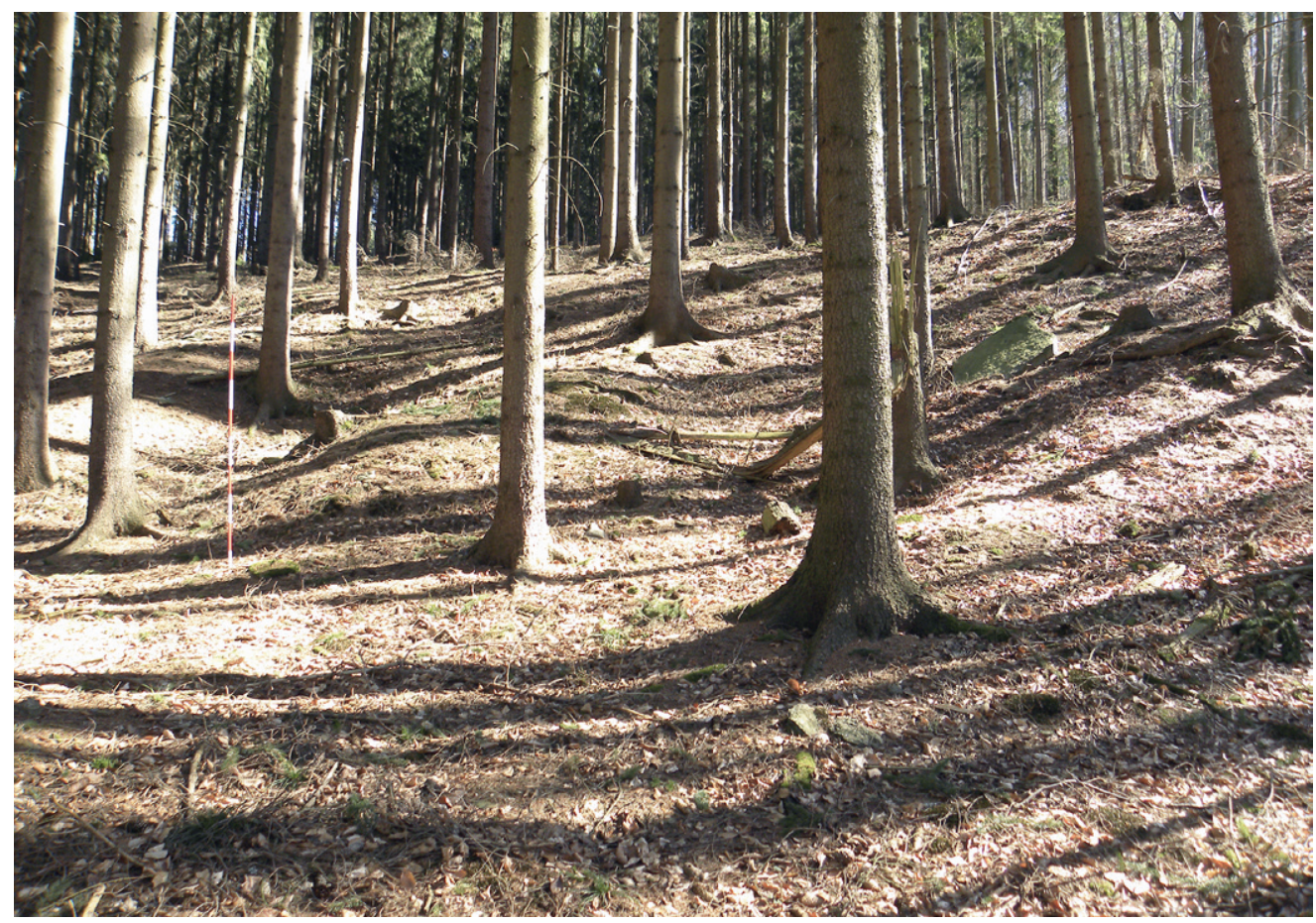

Obr. 23. Stř̌edověký areál těžby stříbra Havírna u Štěpánova nad Svratkou. Destrukce tří objektů na okraji terasy vjihozápadní části komplexu (srov. obr. 22). Foto J. Doležel, duben 2019.

Fig. 23. Medieval silver mining area Havírna near Štěpánov nad Svratkou. Destruction of three features on the edge of the terrace in the south-western part of the complex (cf. Fig. 22). Photo by J. Doležel, April 2019.

\subsubsection{Sídlištní a správní segmenty štěpánovské Havírny}

Integrální součástí báňských areálů středověku i časného novověku byla obydlí horníků, havířů, důlních úředníků, dělníků, řemeslníků a zaměstnanců, stejně jako stavební objekty související se správou a provozem dolů: jak svědčí kupř́íkladu privilegium markraběte Přemysla pro Uničovské z roku 1234, profesní a právní výlučnost vymezovala hornické komunity mimo běžné sídelní struktury. ${ }^{10}$ Výzkum hornických sídlišt při důlních dílech jako specifické komponenty spektra středověkých sídelních forem zaznamenal v uplynulých čtyřiceti letech značné pokroky. Dal přitom vyniknout celé řadě shodných rysů těchto osobitých útvarů, plně konvenujících s kosmopolitním charakterem a oborovou specializací hornické society evropského středověku, sledovatelných v širokém geografickém pásu Evropy, od karpatského oblouku přes Alpy a středoevropské vrchoviny po Alsasko. Vedle v zásadě provizorního a současně konjunkturálního rázu byla hornickým sídlištím společná zejména těsná prostorová i funkční vazba na samotné horní dobývky a úpravní i hutní zařízení. Stejně tak je charakterizovala maximálně účelná systémová skladba, převážně utilitární urbanistický koncept, ovšem se silnou tendencí k normativním modulům, a zcela obvyklá kombinace nadzemní zástavby dřevěné konstrukce s archeologicky markantními zahloubenými suterény, souvisejícími zřejmě s dominantně spotřebním rázem středověkých hornických komunit. Nápadná je bohatá archeologizovaná materiální kultura, reflektující patrně specifickou mentalitu obyvatel těchto lokalit (srov. sumárně kupř. Nováček 1994; 2001, 299-300; Bailly-Maître 2002, 167-175; Steuer, Goldenberg 2002; Schwabenicky 2011, 17-22; Derner 2015, 110-126; 2017, 132-148; Derner, Hrubý 2018; Hrubý 2019, 166-181; Crkal et al. 2019; Hrubý et al. 2019a, 879-886).

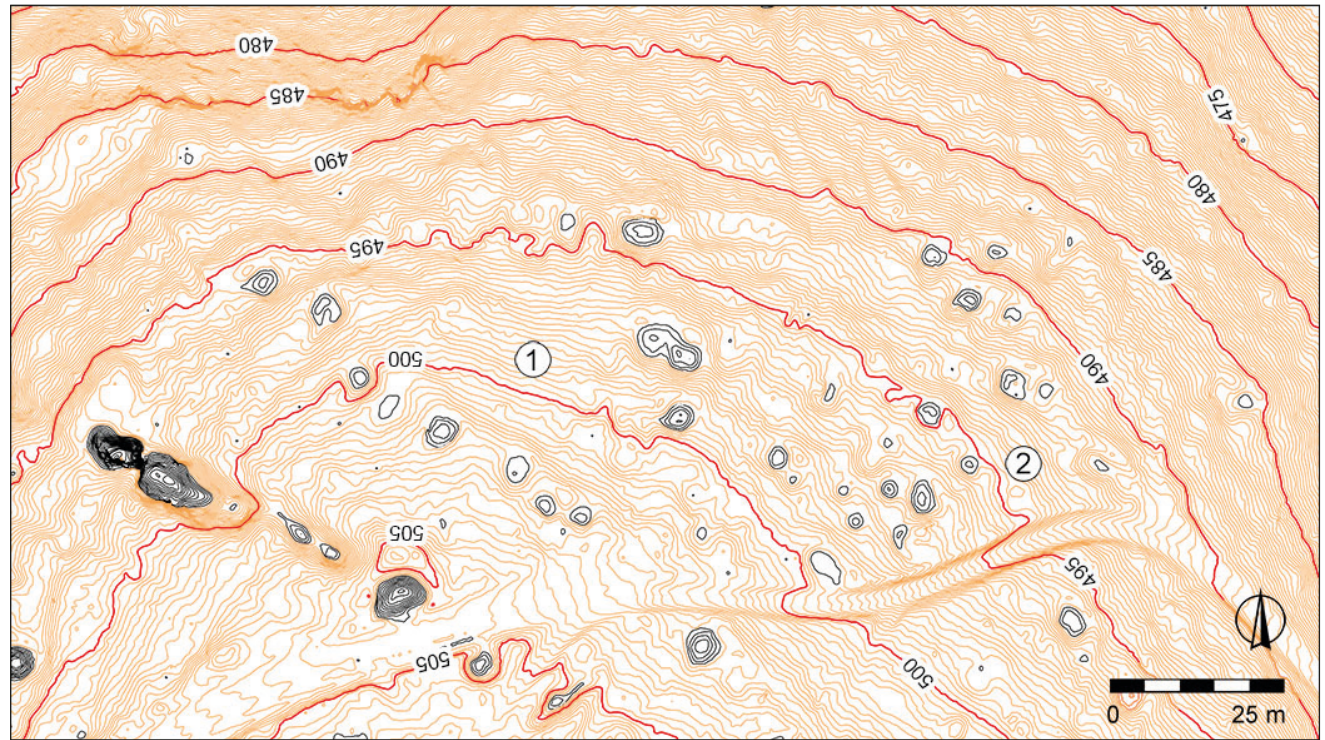

Obr. 24. Středověký areál těžby stříbra Havírna u Štěpánova nad Svratkou. Centrální sídelní útvar ve středním oddílu. K uskupení zástavby (1) se další obdobné objekty připojovaly na východě a jihovýchodě (2). Výřez vrstevnicového znázornění digitálního modelu terénu (2017-2019), autor M. Tejkal.

Fig. 24. Medieval silver mining area Havírna near Štěpánov nad Svratkou. Central settlement in the middle section of the mining complex. Other similar features were connected to the triangular grouping of buildings (1) in the east and south-east (2). A cut-out of the contour representation in a digital terrain model (2017-2019), author M. Tejkal. 


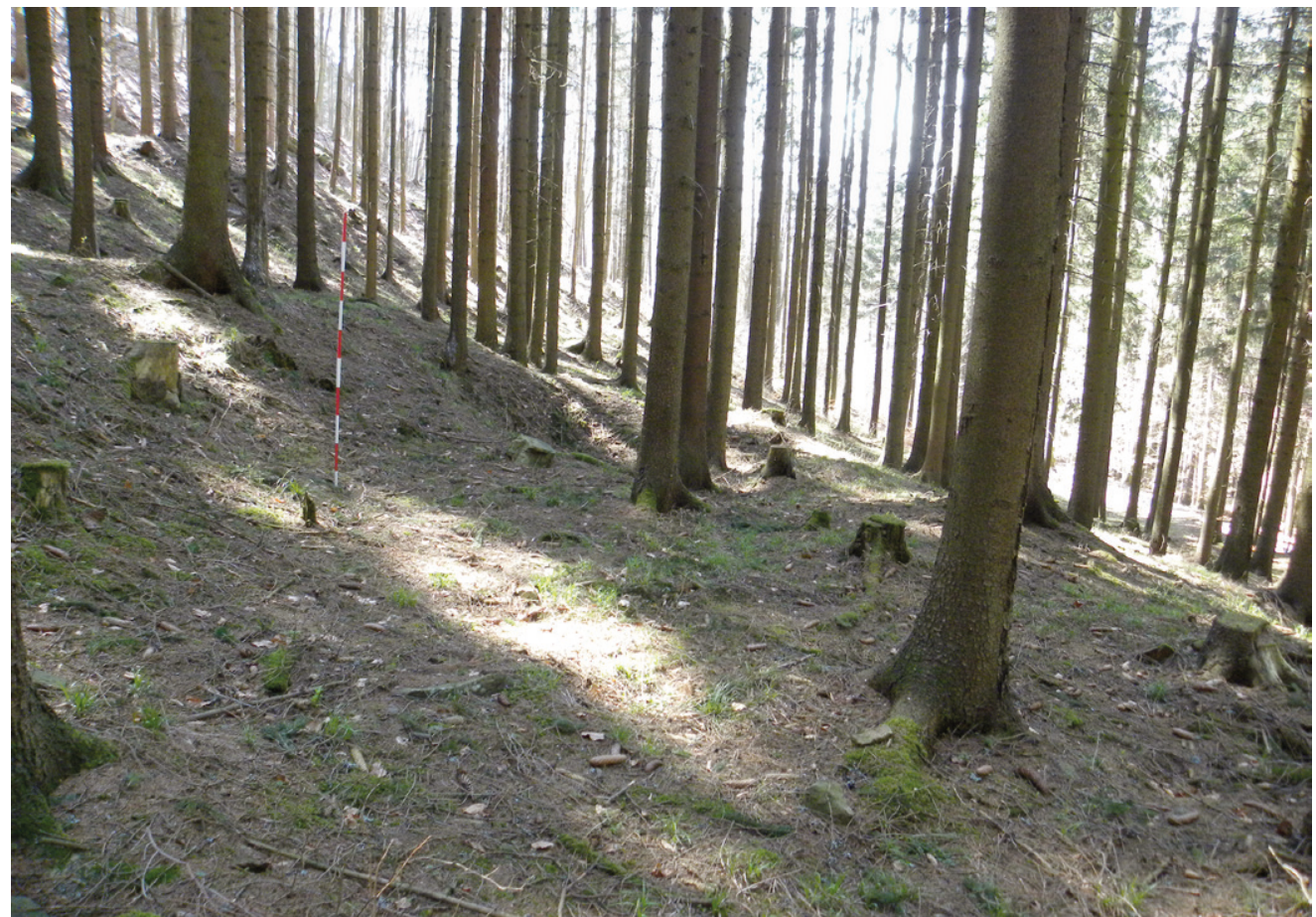

Obr. 25. Středověký areál těžby stř́ibra Havírna u Stěpánova nad Svratkou. Sídelní okrsek př severozápadním okraji lokality. Sídelníterasa o rozměrech $15,8 \times 7,2 \mathrm{~m}$, s reliktem suterénu 4,3 × 4,3 m při západním konci terasy. Foto J. Doležel, duben 2019

Fig. 25. Medieval silver mining area Havírna near Štěpánov nad Svratkou. Settlement district on the north-western edge of the site. Settlement terrace measuring $15.8 \times 7.2 \mathrm{~m}$, with a relic of the basement $4.3 \times 4.3 \mathrm{~m}$ at the western end of the terrace. Photo by J. Doležel, April 2019.

Jak již bylo zdůrazněno, plně do nastíněného konceptu zapadá i středověké hornické osídlení štěpánovské Havírny (Doležel, Sadílek 2004, 55, 57, 71-75). Stejně jako vlastní důlní práce a objekty spjaté s úpravou a hutněním vydobytých rud, rovněž sídlištní, rezidenční a obslužné komponenty lokality vyžadují detailnější verifikaci a interpretaci, diferencující kupříkladu relikty suterénů obytných a správních objektů od prospekčních šachtic či odlišující jednotlivé dílenské a sídlištní koncentrace; podrobná terénní rekognoskace veškerých zaměřených antropogenních útvarů na lokalitě byla zahájena v květnu 2020. Nezbytné budou i cílené archeologické odkryvy vybraných situací, umožňující vedle základního funkčního rozlišení formulovat určitější hypotézy o půdorysné dispozici a vnitřní skladbě obytných domů a dalších staveb. I s přihlédnutím k četným analogiím je však možné na základě provedené dokumentace alespoň předběžně formulovat určité hypotézy k základní organizaci sídelních segmentů na štěpánovské Havírně. Nespornou výhodu, zvyšující interpretační potenciál, tu představuje jak vynikající zachování povrchového reliéfu, tak situování báňského areálu převážně v silně svažitém terénu, jež si vynutilo důsledné terasování svahů pro jakoukoliv stavební činnost (tuto výraznou specifiku Havírny zdůraznili již Crkal et al. 2019, 891; Hrubý et al. 2019a, 880). V obdobné geomorfologické situaci položených a vybudovaných báňských sídlištních areálů lze v oblastech členitých horských pásem Evropy zaznamenat přirozeně celou řadu. Jmenovat lze kupř́kladu osady na dobývkách Riestergang a Birkenberg v jižním Schwarzwaldu, Bastenberg a Silberkaule v porýnském Sauerlandu, na některých důlních dílech v hlubokých údolích Karpat (Staré Hory - Haliarská dolina, Malachov Fišiarka a další četné na Horehroní). Nezbytné bylo takovéto umístění pro havířská sídliště ve vertikálně extrémních terénech alpských báňských revírů, namátkou zde lze zmínit kupř́íkladu Gasteinské údolí ve Vysokých Taurech, Kogelmoos ve schwazském revíru či více lokalit ve východních Korutanech. ${ }^{11}$

$\mathrm{Na}$ základě předběžně interpretace výsledků nového zaměření se základní modul sídlištní složky štěpánovské Havírny jeví značně diverzifikovaný, částečně zřejmě i v souvislosti s chronologií a vnitřní organizační strukturou areálu; za rozrůzněností mohly přitom stát důvody jak sociálně-právní, tak ekonomicko-funkční. Je tomu tak shodně s některými dosud zkoumanými hornickými sídlišti, příznačnými spíše širším rozptylem jednotlivých sídlištních shluků či izolovaně situovaných objektů, zatímco jiné hornické osady charakterizuje spíše jednodušší, koncentrovaná podoba urbanistické struktury, at již byly vzájemné relace k vlastním důlním a úpravním provozům jakékoliv (souhrnně k urbanismu těchto útvarů např. Kenzler 2012, 155-162; 2014, 161-162, 166, obr. 6, 7; Derner 2015, 111-114, obr. 4, 5; 2017, 132-136; Derner, Hrubý 2018, 215-224; Hrubý 2019, 67-77, 166-172, obr. 31, 32, 34, 35, 37, 39, 117, 119; Crkal et al. 2019, 888-891, obr. 1-3; Hrubý et al. 2019a, 879-881).

Celkem lze na štěpánovské Havírně rozlišit nejméně tř̀i různě organizované sídlištní segmenty. Dokumentace především potvrdila a znovu zdůraznila možný význam koncentrace sídlištních objektů v ústřední části areálu, při okrajové hraně výběžku ploššího terénu nad strmým svahem potočního údolí, ve výškovém rozmezí 490-500 m n. m. (obr. 8, 24; srov. Doležel, Sadílek 2004, 57, 61, obr. 16). V terénu sledovatelná zástavba, indikovaná sídlištními terasami spolu s př́slušnými suterény, v některých př́padech i víceprostorovými a se stěnami zpevněnými kamennými plentami, zde vytvář́i soustředěný útvar. Evidentní je vazba celého tohoto sídlištního uskupení na střední stěžejní tah dobývek, řada přibližně deseti suterénů jej sledovala v distanci 10-20 m od severovýchodu. Další zástavba dle dochovaných reliktů navazovala na jednotlivých terasách dále na severozápadě a východě. Popsaná struktura s náznaky ortogonálního rozvrhu a volného středového prostranství implikuje hypotetickou představu sídelně-správního ústředí celého důlního areálu, s rezidencí perkmistra a dalších orgánů důlní správy, s nejdůležitějšími obslužnými provozy a místem vymezeným pro trhové aktivity. Je třeba rovněž zdůraznit polohu této plochy v komunikačně klíčovém centrálním prostoru celé lokality, kde se stýkaly a větvily nejméně čtyři stěžejní komunikační trasy, vybíhající odtud k jednotlivým dílům důlního areálu.

Archeologické nálezy potvrzují osídlení uvedeného útvaru v zásadě v 2. polovině 13. století. Existenci obdobných ústředních částí hornických sídlišt s určitou otevřenou plochou, „tržištěm“ 


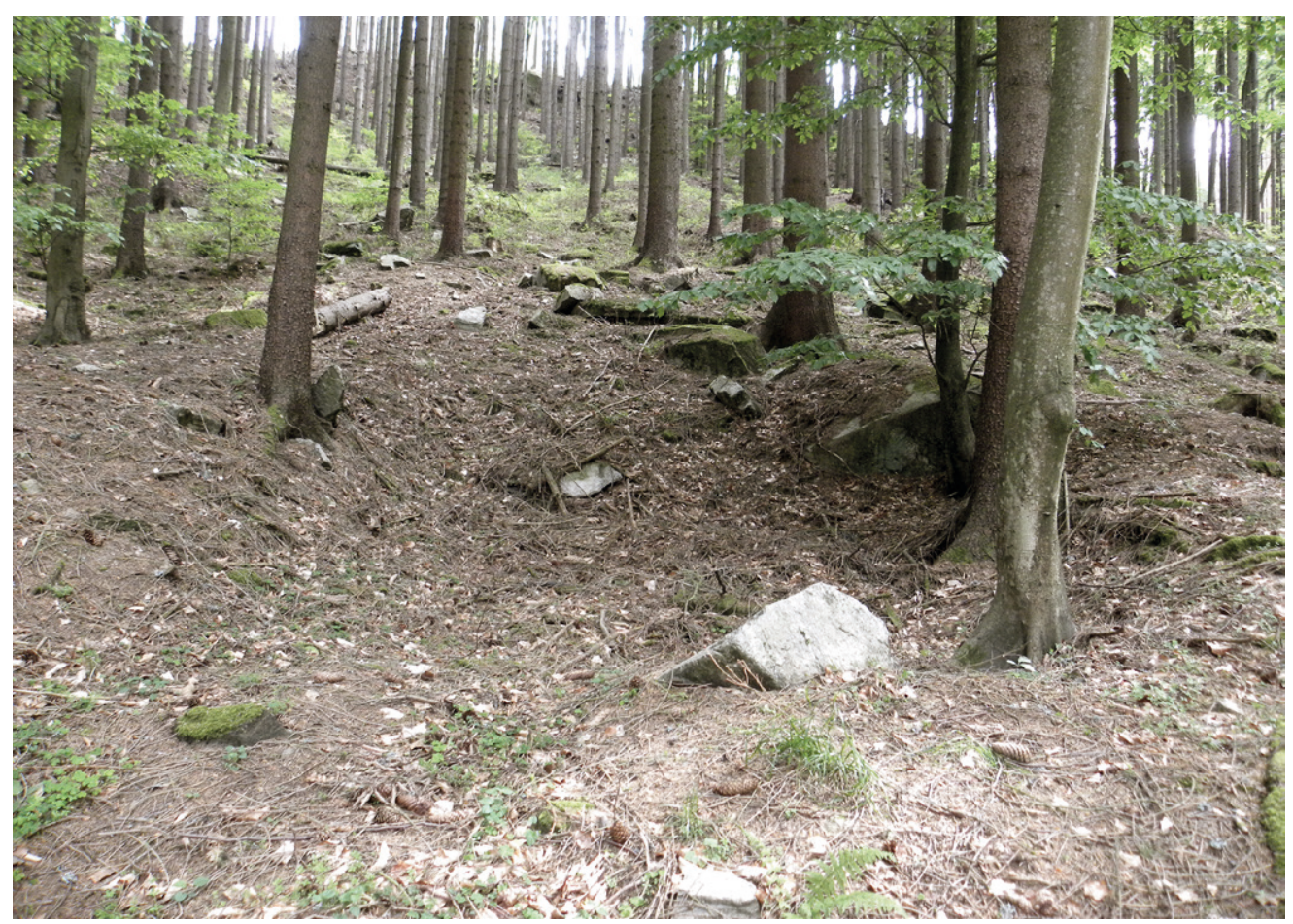

Obr. 26. Stř̌edověký areál těžby stř́bra Havírna u Štěpánova nad Svratkou. Sídelní koncentrace při severním okraji důlního pole, vohybu silnice Záskalí - Čtyři Dvory. Výrazný relikt suterénu. Foto J. Doležel, květen 2020.

Fig. 26. Medieval silver mining area Havírna near Štěpánov nad Svratkou. Settlement concentration on the northern edge of the mining field, at the bend of the Záskalí - Čtyři Dvory road. A distinctive relic of the basement. Photo by J. Doležel, May 2020.

ve svém středu, lze přitom předpokládat na více lokalitách. Z bližších oblastí Vysočiny lze zmínit geomagnetickou prospekcí dokumentovaný báňský sídelní areál na Buchbergu u Utína na Brodsku, kde jsou zahloubené části zástavby koncentrovány kolem čočkovitě protaženého prostoru o délce $155 \mathrm{~m}$ a šířce až $60 \mathrm{~m}$, nebo stejnou metodou detekované montánní sídliště v trati Štětinka jižně od Vyskytné na Pelhřimovsku, s náznakem podélné $(80 \times 40 \mathrm{~m})$ nezastavěné plochy v jižnější polovině zkoumaného polygonu (dosavadní vyhodnocení přitom ovšem zdůrazňují základní liniovou koncepci těchto útvarů, srov. např. Derner et al. 2016, 226-227, 237-238, obr. 14, 17, 35, 36; Hrubý 2017, 3-5, obr. 3-8; 2019, 73, 75-77, 139, 169-172, obr. 35, 39, 105, 117, 119; Derner, Hrubý 2018, 219-221, obr. 7, 8; Crkal et al. 2019, 889-891, obr. 3). V zásadě trojúhelné prostranství $160 \mathrm{~m}$ dlouhé a až $90 \mathrm{~m}$ široké vymezovaly normativně uspořádané fronty domů č. IV-X, XI-XVIII a XXX-XXXIII v osadě při stř́ibrných dolech na krušnohorském Kremsigeru (Derner 2015, 109-114, obr. 3, 5; 2017, 37-39, 134, 155, 213, 214, 265, obr. 10, 12; 2018a, 316-319, 327-329, obr. 249; Crkal et al. 2019, 889, obr. 2). Na Altenbergu v porýnském Siegerlandu pak v rámci hornického sídliště situovaného v sedle horského hřbetu archeologický výzkum odkryl domy nadzemní dřevěné konstrukce na kamenných podkladech (věncích) se zahloubenými suterény s kamennými plentami, včetně ústřední věžové kamenné budovy (Fundstelle 3: Lobbedey et al. 1998, 21-132, plány 1-5, zvl. 22-31, 38, obr. 5). Situaci lze opět interpretovat jako seskupení stavebních objektů kolem protáhlého ústředního prostoru $80 \times 20 \mathrm{~m}$.

Druhý povrchovou prospekcí identifikovatelný sídlištní komplex lze na Havírně zaznamenat při dolním severozápadním okraji důlního areálu, prakticky pod celým průběhem severního obvalového tahu, v pásu asi $290 \mathrm{~m}$ dlouhém a $50 \mathrm{~m}$ širokém. Ve svahu nad potočním úžlabím Záskalského potoka je tu ve výškové distanci okolo 420-440 m n. m. dochováno seskupení přibližně tří desítek spíše menších sídlištních teras, v některých případech se zřetelnými pozůstatky zahloubených suterénů, bud' při jednom z konců plošin, nebo situovaných i samostatně; celkový počet těchto konkávních útvarů zde dosahuje více než dvou desítek
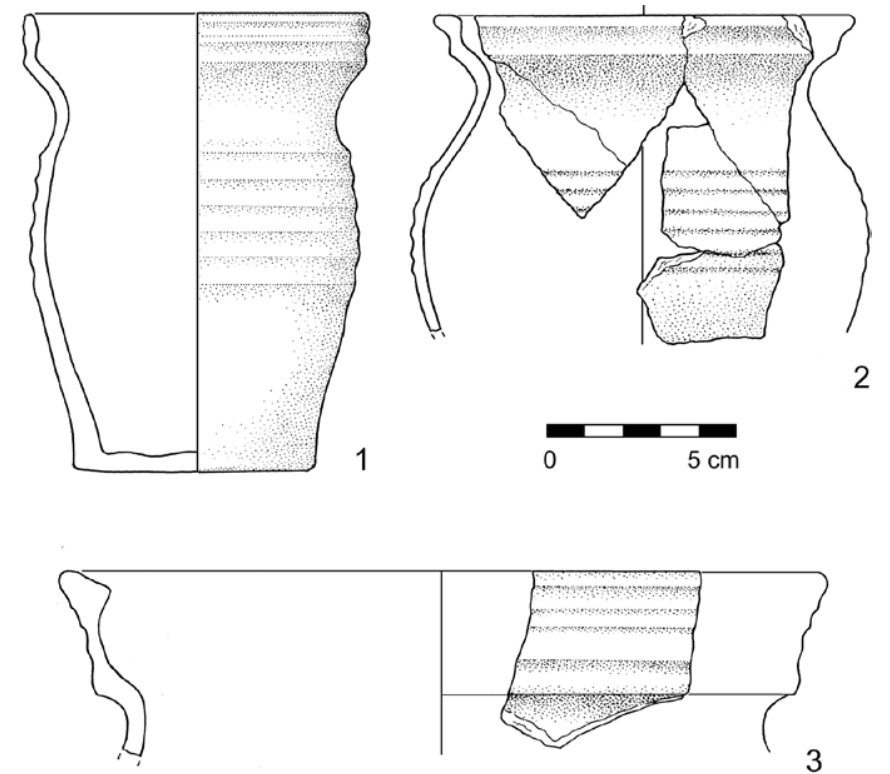

3

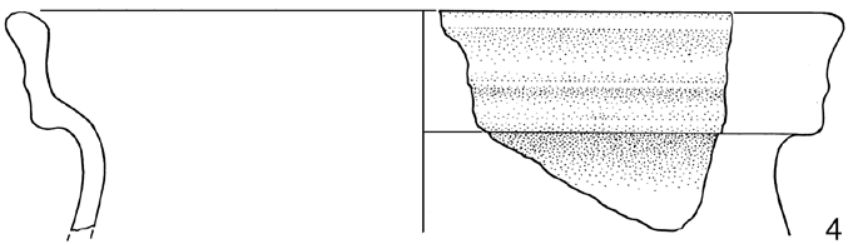

Obr. 27. Středověký areál těžby stříbra Havírna u Štěpánova nad Svratkou. Sídelní segment na severozápadním okraji lokality. Keramika konce 14. století. Kresba M. Kejzlar a S. Plchová.

Fig. 27. Medieval silver mining area Havírna near Štěpánov nad Svratkou. Settlement segment on the north-western edge of the site. Ceramics from the end of the $14^{\text {th }}$ century. Drawing by M. Kejzlar and S. Plchová. 
(obr. 8, 25, 26; srov. též Doležel, Sadílek 2004, 55, 57, obr. 12). Množství teras s příslušnými suterény bylo zřejmě ještě větší, plocha tu však byla narušena jak probíhající novodobou silnicí ze Záskalí do Čtyř Dvorů, tak zářezem a oběma haldami novověké průzkumné štoly (překopu) Václav. Markantní sestavu tří teras, v těsné řadě diagonálně stoupajících svahem, lze sledovat v západním sousedství této štoly, skupina dalších pěti plošin je poněkud volněji rozložena východněji. Jiné útvary tohoto typu je možné pozorovat $\mathrm{v}$ několika koncentracích zejména nad východním ohybem silnice, v rozptýlenější sestavě ale i na západním konci.

Právě ve východním ohybu bylo několik sídlištních objektů různých typů dokumentováno navíc v kompozicích, dovolujících uvažovat o složitěji strukturovaných sídlištních jednotkách, havírských usedlostech; škálu zachovaných reliktů je tu možné rozširrit i o základové kamenné věnce nadzemních dřevěných konstrukcí, kamenné podesty domů a dělicí zídky vyskládané opět z kamene na sucho nebo na hliněné pojivo. Takovéto objekty tu přitom vytvářejí kupř́íkladu dvojici jen mírně do svahu zahloubených podest stavení doprovázených terasami, dvoudílný, částečně zahloubený objekt tvaru „L“s výše položeným sklípkem, nebo zde lze zaznamenat pozůstatky patrně podélného domu na kamenné podestě se suterénem $5,3 \times 5,5 \mathrm{~m}$ ve své západní polovině, na východě s drobným sklípkem $2,0 \times 2,1 \mathrm{~m}$ a navazujícím zadním dvorem, od západu odděleným zalomenou ohradní zídkou.

Artefakty z povrchové a detektorové prospekce datují osazení této části Havírny opět do 2 . poloviny 13 ., ale i do počátku 14. věku. Na rozdíl od jiných partií ovšem zatím pouze zde byly v hojnější míře zachyceny pozůstatky mladšího osídlení, jdoucího až do 2. poloviny 14. století. Jedná se o nevelký segment v západním dílu lokality, zřetelně existující v prakticky již opuštěné „hoře“: k ukládání kuchyňského odpadu zde tehdy posloužila pinka po jedné z hledacích šachtic (obr. 27). Hypoteticky je snad možné tuto závěrečnou etapu osazení štěpánovské Havírny spojit s provozem jen 120 m severozápadně předpokládané dědičné štoly, jejíž údržbu a alespoň minimální roční ražbu na čelbě bylo nutné provádět pro zachování právních nároků na užitky z př́ípadně obnovené těžby (podrobněji Doležel, Sadílek 2004, 51, 55, 81-87, 116-117, obr. 5: 2, př́loha I: 3). Právě severní sídelní segment Havírny, pro trvalejší osídlení již vzhledem $\mathrm{k}$ blízkosti stálé vodoteče vůbec nejpříhodnější, by mohl být proto totožný se vsí Hohenrod, u níž byla roku 1348 Gobliny propůjčena těžařům dědičná štola „pro využití starých dobývek, v cechu tamtéž ležících“ (Doležel, Sadílek 2004, 81-86, 116-117, př́loha I.3; Flodr ed. 2005, 413-414, č. 1164). Napovídala by tomu i přítomnost skladebně ucelenějších komplexů sídelních objektů, korelující s jejich patrně mladší datací. Spolehlivější identifikace zůstává ovšem úkolem dalších výzkumů, proti právě nastíněné hypotéze hovoří naopak některé jiné argumenty, například jen omezené možnosti alespoň sekundárního využití okolních terénů pro zemědělství, i typicky „kolonizační“, „mýtební“ toponymum Hohenrod, nesouvisející nijak s prvotním dolováním (za př́nosnou diskusi nad problematikou závěru osídlení na štěpánovské Havírně děkuji Kryštofu Dernerovi).

Výrazná formace zhruba dvacítky rozměrově většinou analogických teras doprovází ve dvou řadách cestu, od západu napřič stoupající svahem v západní části lokality, a to v pásu $200 \mathrm{~m}$ dlouhém, prakticky od dolního ohybu cesty na západě až zhruba do poloviny svahu ve výškovém rozsahu okolo 440-474 m n. m. (obr. 8, 28). Konfigurace teras tak současně dokládá středověké stáří dnes obnovené komunikace, zcela zřejmě stěžejní př́istupové trasy, spojující báňský areál Havírny s vlastním svrateckým údolím na západě. Stejně jako u jiných sídelních areálů na Havírně, také zde při primární analýze nelze nevzpomenout na ustanovení mladších redakcí jihlavského horního práva i Ius regale montanorum Václava II., podle kterých měla mít každá řádná vyměřená důlní míra o sedmi lánech právo na zřízení šestnácti svobodných obytných městišt (area, hofstatt, dvořiště), s potřebným počtem masných a chlebných lavic, lázní, volným trhem i výčepem piva, medoviny a vína (CDB IV. 1, 325, č. 177, čl. IIa; Zycha 1900b, 10, 23, 134-135, 156-157, 335-336, § 9, § 8[2], Lib. II, Cap. 3/I, § 1, Lib. II, Cap. 4/V, § 24, č. 27-29; Bretholz 1903, 233, 239; Hoffmann ed. 1959, 61, čl. 108; Bílek ed. 2000a, 44, 49, Cap. III, § 1, Cap. IV, § 24; cf. Zycha 1900a, 180-182).

Bezpečná interpretace této koncentrace antropogenních terénních útvarů jako dalšího sídlištního báňského areálu však zatím není možná, i přes některé analogie v urbanistické skladbě dalších hornických osad středověké Evropy: v semknuté dvouřadé, extrémně dlouhé linii byla koncipována obytná zástavba na saském Treppenhaueru, výrazně lineární a zhuštěný víceřadý rozvrh měla rovněž sídelní část důlního areálu Brandes ve francouzském Dauphiné, geofyzikální prospekce nově indikovala dvouřadé ulicovité uspořádání zástavby rovněž v jihozápadní

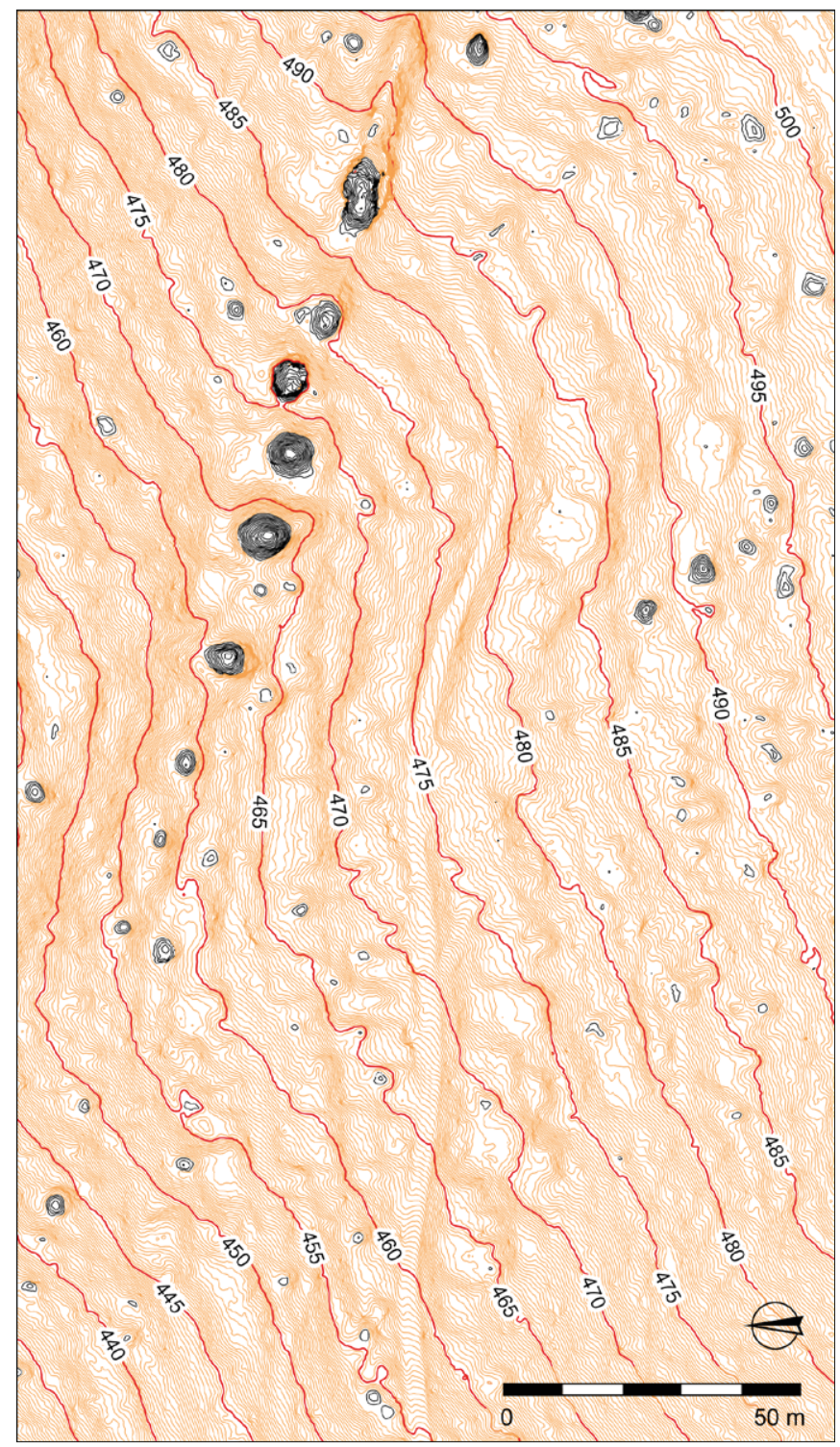

Obr. 28. Středověký areál těžby stř́ibra Havírna u Štěpánova nad Svratkou. Uskupení teras podél komunikace vzápadní třetině důlní plochy. Výřez vrstevnicového znázornění digitálního modelu terénu (2017-2019), autor M. Tejkal.

Fig. 28. Medieval silver mining area Havírna near Štěpánov nad Svratkou. Grouping of terraces along the road in the western third of the mining area. A cut-out of the contour representation in a digital terrain model (2017-2019), author M. Tejkal. 
části lokality Cvilínek u Černova na Českomoravské vrchovině (Bailly-Maître, Bruno-Dupraz 1994, 15-16, 139-154, obr. 78-80, tab. II; Schwabenicky 2009, 21-22, 34-78, 226-232, obr. 18; Kenzler 2009, 263-279, 289-300, obr. 1, 4; 2012, 156-158, 161, obr. 198, 109, 113; 2014, 161-162, 166, obr. 6; Hrubý 2019, 174, obr. 121; Crkal et al. 2019, 891, 893, obr. 4). Z dvouřadé sestavy teras v západním dílu štěpánovské Havírny však zatím chybějí prokazatelnější doklady sídelního využití, nápadná je také absence zřetelnějších stop zahloubených suterénů na jednotlivých plošinách. Na východě navíc na tuto linii navazuje série větších teras s indiciemi využití spíše v úpravních, dílenských či hutních provozech; obdobné větší terasy, někdy i dělené příčnými nasucho z kamene kladenými zídkami, probíhají ve dvou liniích níže v severním svahu (obr. 20, 21, 28; srov. též Doležel, Sadílek 2004, 55, 60, obr. 13, 14). O spolehlivější funkční identifikaci této nesporně významné části důlního areálu na Havírně tak opět rozhodne další etapa studia.

Vedle hypotetických dvou až tři soustř̌eděnějších sídlištních koncentrací, u kterých je třeba zdůraznit jejich ne vždy bezprostřední vazbu na jednotlivé sledy dobývek i tendenci k normativnímu uspořádání, lze na štěpánovské Havírně předpokládat další rozptýlenější osídlení. Shluky nebo jednotlivá obydlí a cechovní stavby mohly být budovány přímo u šachet či dalších provozů jak ve srázném severním svahu, tak zejména v pozvolnější jižní části. Jejich spolehlivější identifikaci přinese snad detailnější ověřovací prospekce. Suterén stavby se stěnami zpevněnými plentou z nasucho kladeného lomového kamene je možné kupř́ikladu zaznamenat v těsné blízkosti velké šachty ve východní polovině spodního, nejsevernějšího tahu obvalů, více suterénů zřejmě paralelně sleduje počátek východnější poloviny středního obvalového pásu. Analogická situace se dvěma řadami obydlí či cechovních budov, lineárně rozmístěných podél pinek, byla dokumentována na zlatohorském Altenbergu v Jesenících (Večeřa, Večeřová 2007; Večeřa 2013, 50-51, obr. 10). Obdobně velmi důsledně a v těsné distanci doprovázely v rovnoběžné skladbě domy horníků linii šachet na důlním díle 13. století Silberkaule v porýnském Siegerlandu (Gechter 2003, 156-161). Další objekty tohoto typu zaujaly ale na Havírně volně také velmi strmý sráz mezi severním a středním těžním pásmem, zde ve zřetelných relacích a spojitosti s některými velkými šachtami (obr. 29, 30).

Nedílnou součástí provozů štěpánovské Havírny musela být další zařízení a provozy, spjaté s činností dolů, již ve 13. století zohledněné právními normativy. Jistě $\mathrm{k}$ nim náležely havířské lázně, badestuben, nezbytná součást každého standardně ustanoveného důlního cechu, zároveň i zdroj nezanedbatelných finančních př́ijmů (srov. např. Zycha 1900a, 180-182). Zde je možné připomenout dvojici menších suterénů s velkými pecemi, odkrytých na saském Treppenhaueru, stejně jako obdobný objekt (stavba 0582) na Cvilínku na Pelhřimovsku, které lze patrně oprávněně interpretovat právě jako pozůstatky lázní (Schwabenicky 2009, 72-77; 2011, 20-21, obr. 26, 27; 2014, 169, obr. 11; Hrubý et al. 2012a, 381-384, obr. 78-80; Derner, Hrubý 2018, 219, 226-227, obr. 6, 14). Stejně tak šlo o kovárny, na archeologicky zkoumaných důlních lokalitách zachycené kupř́íkladu na zlatodolech u Čeliny, na výšině Břemeno u Horské Kvildy, na Buchbergu u Utína, u dolů v Gasteinském údolí ve Vysokých Taurech, na jihotyrolském Schneebergu či ve francouzském Brandes. Totéž se týká krámců a řeznických pracovišt', výzkumem odkrytých opět v důlním areálu 15.-16. století Schneeberg/ Moos v údolí Passeier v jižním Tyrolsku (Kudrnáč 1987, 229-245, obr. 8, 14-23; Fröhlich 2006, 35-37; Hrubý 2019, 141-144; Cech 2007, 43-53; Holdermann 2015b, 96-103; 2015c, 70-79, obr. 3-12; Bailly-Maître, Bruno-Dupraz 1994, 92-100, obr. 49-56; Bailly-Maître 2010, 228-230, obr. 6). Obdobně nepostradatelné byly chlebné a ševcovské lavice, šenky, vážní objekty, směnárny, plochy vymezené pro trhy. Také havírenské doly bezpochyby obklopovaly pomocné objekty, deponie surovin a stavby pro ustájení hospodářských zvířat. Nápadná koncentrace artefaktů spojených s využitím koně, detektorovým průzkumem indikovaná na jižním méně svažitém okraji Havírny, dovoluje do tohoto prostoru snad umístit sklady koňmo dováženého materiálu a stáje s navazujícími ohradami.

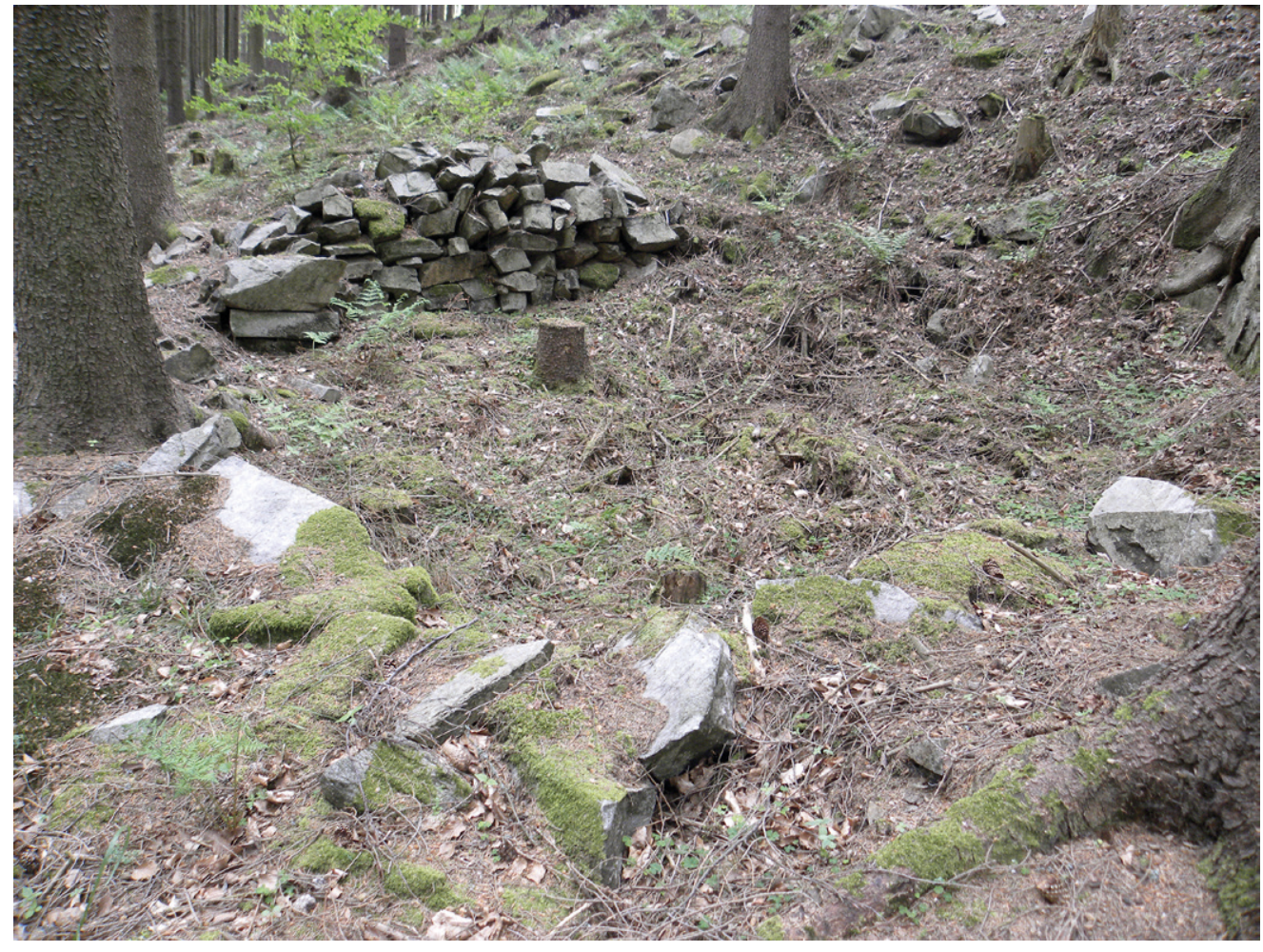

Obr. 29. Středověký areál těžby stříbra Havírna uštěpánova nad Svratkou. Relikt izolované stavby využívající kamenných, na sucho či hlinité pojivo kladených konstrukcí, situované ve svahu nad severním obvalovým tahem. Foto J. Doležel, květen 2020.

Fig. 29. Medieval silver mining area Havírna near Štěpánov nad Svratkou. Relic of an isolated structure using stone, dry or with clay mortar, situated on a slope above of the northern line of shafts. Photo by J. Doležel, May 2020. 
Jakékoliv zevrubnější závěry o skladbě a charakteru vlastní zástavby, jejím rozčlenění i parcelaci nelze formulovat bez alespoň omezených, cílených archeologických odkryvů vybraných nálezových situací, stejně jako podrobné prostorové analýzy pořízené plánové dokumentace. Jen obecně lze podle početných analogií i na základě markantních terénních reliéfních reliktů předpokládat nadzemní dřevěnou zástavbu v podobě jedno-, vzácněji i víceprostorových domů či objektů různé konstrukce: sloupové, roubené či rámové - štenýřové, hrázděné. Stěny staveb mohly být založeny jak ve žlabech, tak na základových kamenných věncích, na sucho či na hlinité pojivo kladených zídkách či na jednotlivých podložních kamenech; samozřejmou součástí domů byla otopná zařízení širší funkční a konstrukční škály. Evidentní je i u hornického osídlení na štěpánovské Havírně rozsáhlé využití polo- nebo zcela zahloubených suterénů hospodářské, úložné nebo specificky provozní funkce; vzhledem k obecné dostupnosti kvalitního kamene zpevňovaly stěny havírenských suterénů zřejmě zcela obvykle kamenné plenty, kladené na sucho či na hliněné pojivo ( $\mathrm{k}$ diskusi o funkci zahloubených prostor na montánních sídlištích evropského středověku srov. kupř. Kenzler 2009, 289-294; Derner, Hrubý 2018, 222-228; Crkal et al. 2019, 892-913; Hrubý 2019, 176-181). Př́íkladů zástavby hornických osad, kombinující dřevěné nadzemní stavby se suterény, byla $v$ Evropě archeologickými výzkumy odkryta celá řada. ${ }^{12}$

Obecnější rezultáty o urbanistické skladbě a sociotopografickém i technologicko-funkčním rozčlenění hornického osídlení Havírny u Štěpánova nad Svratkou mohou mít vzhledem ke stupni poznání pouze hypotetickou platnost. Zohlednit je třeba přitom možnou existenci obslužné důlní zástavby na lokalitě v mladších fázích, za případné obnovy těžby, zejména v 15.-16. a v 18. století, kam by hypoteticky mohly náležet některé nápadně intaktně dochované substrukce. Jak se zdá, celkové uspořádání obytných a provozních objektů zde ale bylo ve vrcholném období těžby 13 . a počátku 14. věku v zásadě disperzní a odpovídalo modelu, ve vrcholně středověkých horních revírech velmi často uplatněnému na centrálních či významnějších důlních lokalitách širšího významu. Jejich charakteristickým prvkem byla existence hned několika soustředěnějších sídelních uskupení v různých úsecích kutacího areálu, někdy částečně nebo i zcela normativně koncipovaných, vybudovaných bez primární vazby na samotná důlní díla. Tyto kompaktnější organismy doplňovala pak další rozptýlená menší jádra, paralelní struktury či jednotky, zřetelněji již sledující vlastní dobývky, či dokonce konkrétní jednotlivá důlní díla. Jmenovat je možné zejména některé analogie z centrálních oblastí Vysočiny: Buchberg u Utína, Cvilínek u Černova, Staré Hory u Jihlavy (Derner, Hrubý 2018, 215-221, obr. 5, 8; Hrubý 2019, 67-76; Crkal et al. 2019, 891; Hrubý et al. 2019a, 880).

V prŕípadě Havírny mohl být jedním z důvodů rozptylu zástavby do více částí důlního areálu členitý terén, znemožňující existenci soustředěné, jednotně rozvržené zástavby. Jak ale naznačují situace na právě vyjmenovaných obdobných areálech v rámci Českomoravské vrchoviny, položených v podstatně plošším reliéfu, za primární př́íčnu vícečetných sídelních uskupení na těchto ústředních lokalitách bude třeba považovat zejména jejich rozdělení na více jednotlivě vyměřených hor, s individuálně vytvořenou doprovodnou obslužnou infrastrukturou, tedy důvody v zásadě ekonomicko-právní a provozní. Pominout však přirozeně nelze ani značnou vývojovou dynamiku hornických sídlišt', s možnými dílčími přesuny v průběhu delšího trvání těžby: jednotlivé sídelní areály v rámci jedné lokality mohly vznikat i zanikat postupně, v závislosti na postupu a bilanci exploatace.

\subsubsection{Sakrální stavba na štěpánovské Havírně?}

Vzhledem k charakteru Havírny jako centrálního montánního areálu štěpánovského rudního revíru (cf. Derner et al. 2019, 926-933) je legitimní otázka existence sakrální stavby, nejspíše kaple, v rámci samotného důlního prostoru. Při dobývkách drahých kovů evropského stř̌edověku jednotlivé, nevelké hornické kaple a kostely za určitých okolností někdy vznikaly, a to i v pouze krátkodobě exploatovaných nebo extrémně položených lokalitách. Důvodem

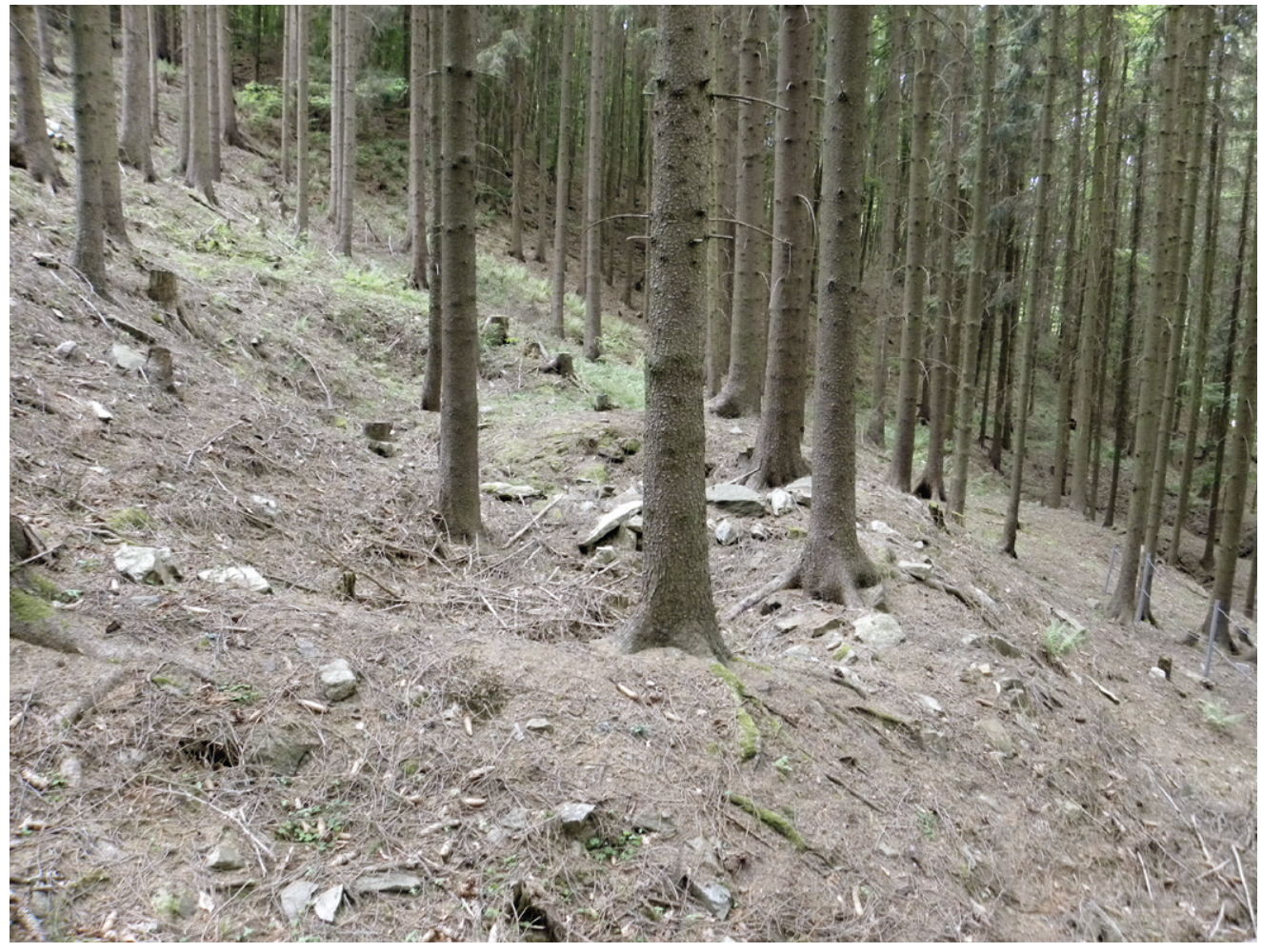

Obr. 30. Středověký areál těžby stř́bra Havírna u Štěpánova nad Svratkou. Pozůstatek izolované víceprostorové (cechovní?) budovy ve srázu nad severním pásmem dobývek. Foto J. Doležel, květen 2020.

Fig. 30. Medieval silver mining area Havírna near Štěpánov nad Svratkou. Remnants of an isolated multi-spatial (guild?) building on a steep slope above the northern zone of the shafts. Photo by J. Doležel, May 2020. 


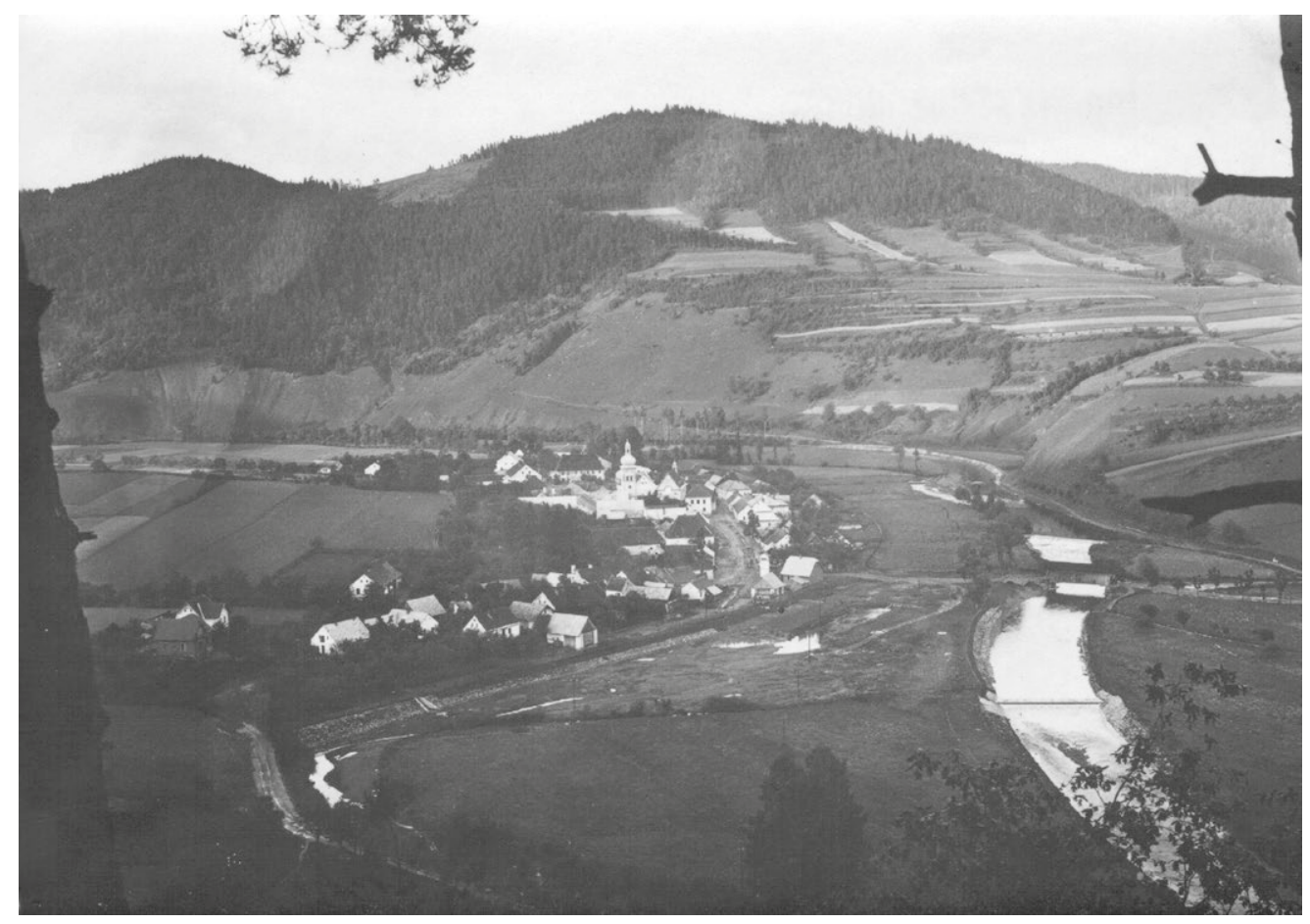

Obr. 31. Štěpánov nad Svratkou. Městečko s kostelem sv. Petra a Pavla na panoramatické fotografii patrně z třicátých let 20. století. Snímek pořízený od jihozápadu, z návrší kozlovského Hradiska, dává vyniknout poloze osady v zákrutu hlubokého údolí řeky Svratky. Prostorem tzv. Sedla na horizontu mezi výšinami Domanínek (vlevo) a Otrubová mohla vést jedna z komunikací spojujících Štěpánov s Havírnou. (c) Městys Štěpánov nad Svratkou a Petr Skokan. Fig. 31. Štěpánov nad Svratkou. Small town with the church of St Peter and Paul in a panoramic photograph probably from the 1930s. The picture was taken from the south-west, from the Kozlov Hradisko hill, it highlights the position of the settlement in the deep valley of the Svratka River in its right bend. One of the roads connecting Štěpánov with Havírna could lead through the area of the socalled Sedlo ("Seat") on the horizon between the heights of Domanínek (left) and Otrubová. ( ) Městys Štěpánov nad Svratkou and Petr Skokan.

mohla být velká vzdálenost či komunikační odlehlost a nepř́istupnost těchto míst, podstatně ztěžující výkon duchovní správy ze stávajících sídel, právní, mentální a socioprofesní výlučnost hornického živlu, bránící širší integraci do místní farní obce věřících, stejně jako etnická odlišnost hornických komunit od domácí populace a tedy i nutnost jejich pastorace ve srozumitelném jazyce. Neméně naléhavou pohnutkou byla ale i vnitřní potřeba samotných horníků a havíruou. Bezprostřední účast na liturgických i mimoliturgických svátostných či zbožných úkonech, vysluhovaných přímo v prostředí důlních cechů, měla získat Boží ochranu a podíl na jejich spásných účincích a darech v náhlých nebezpečích, které hornická profese přinášela; stejně tak měla zajistit (a to i prostřednictvím prrímluvy jednotlivých světic a světců) Boží př́izeň při nejistém nalézání drahých rud coby Božích darů. Specifická zbožnost byla proto stejně charakteristickým rysem středověkých evropských hornických společenství jako jejich exkluzivita i „bezbožnost“, a vedle okázalých chrámových fundací v předních exploatačních centrech (Freiberg, Freiburg im Breisgau, Goslar, Kutná Hora, Złotoryja) nalezla svůj výraz právě v drobných sakrálních stavbách při samotných důlních dílech (obecně např. Schreiber 1962, zvl. 35-87, 211-229, 303-422, 450-475).

$\mathrm{Z}$ archeologicky zkoumaných objektů tohoto typu lze jmenovat kostel sv. Mikuláše $v$ alpské hornické osadě Brandes ve francouzském Dauphiné (s analogií v kostele sv. Vavřince v Saint-Laurent-du-Lac ve stejném regionu), nebo svatyni neznámého patrocinia z konce 12 . věku v poloze Geißmättle u Sulzburgu v jižním Schwarzwaldu (Bailly-Maître, Bruno-Dupraz 1994, 173-179; Rauschkolb 1999; Bailly-Maître 2002, 160-167; Goldenberg, Steuer 2004, 67-69).

Fenomén havířských kaplí, kostelíků a zbožných cechovních bratrstev se pak dále rozvíjel v pozdním středověku, autentickým dochováním (včetně vnitřního vybavení oltáři havířských patronů) vynikají zejména některé svatyně alpských báňských okrsků. Ilustrativně zde lze uvést kapli sv. Maří Magdalény v Ridnaunském údolí Stubaiských Alp, ve schneeberském rudním revíru, roku 1273 již obnovovanou po požáru, či v 15. století (před rokem 1450) vybudovanou hornickou kapli sv. Agáty na Kristbergu ve stř́ibrnorudném revíru Montafon ve vorarlberských centrálních
Alpách. V rámci montafonských dobývek pak vedle dalších tradičních „hornických“ farních kostelů sv. Bartoloměje na Bartholomäbergu a sv. Mikuláše a sv. Mořice v Silberbergu existovala i další kaple (Nejsvětější Trojice a sv. Ducha), založená někdy v letech 1493-1500 hornickým bratrstvem Nejsvětější Trojice, ustaveným roku $1493 .{ }^{13} \mathrm{~V}$ revíru Gossensaß-Sterzing před Brennerským průsmykem pak někdy před rokem 1385 vznikla ve farnosti kostela Panny Marie v Moosu (Sterzing) filiální svatyně v samotném Gossensaß, zasvěcená sv. Jiř́í, při níž již roku 1456 existovala konfraternita horníků a havírư „od dolü“, des pergwerchs, sanct Jörgen bruederschaft der bergkhern und ärztknappen zu Gozzensas. Bratrstvo tehdy u římských kardinálů vyžádalo pro svůj svatostánek odpustky, 1478 u něj dotovalo ranní mši „pro odvrácení nouze dolü“, před rokem 1490 tu došlo ke zřízení další mše, výslovně ustanovené pro zde pracující horníky. Na kostelním hřbitově byla posléze vystavěna patrová „hornická“ kaple sv. Barbory, vysvěcená roku 1515, s nákladným skř́ńnovým oltářem s výjevy práce v dolech (Ottenthal, Redlich 1896, 341-343, č. 1667-1669, 1671-1679, 1682; Schadelbauer 1930a; 1930b; Ungerank, Tropper 2014; ke všem třem výše zmíněným revírům též Srbik 1929, 134-138, 142-151, 220-227, 254-258; ke Schneebergu a Gossensaßu dále Mair et al. 2007).

V českých zemích představuje zdaleka nejvýraznější př́ílad tohoto fenoménu ne méně než jedenáct (!) kaplí, v období primární konjunktury zř́izených u jednotlivých horních cechů kutnohorského rudního revíru (Čelakovský 1916, 41-89; Bartoš 2004, 168-175; Vaněk 2011, 62-79, obr. 1, 2; 2015). Již po polovině 13. století byly zakládány sakrální objekty také v nejvýznamnějších důlních centrech kolem tehdejšího Smilova Brodu: kaple Nalezení svatého Kříže a patrně také sv. Markéty Antiochijské na Mittelbergu, sv. Kateřiny Alexandrijské na Erliwinbergu, svatyně neznámého titulu (sv. Barbory?) na protějším Buchbergu (Somer 2012, 166-182; Somer, Šrámek 2015, 80-85; Gája 2016, 54-69, 80-81, 227-228, obr. 39-42; Hrubý 2019, 174-176; Hrubý et al. 2019a, 883-886). Stejně tak je možné uvést kapli Božího Těla na Zlaté žíle při Šlojiŕřském pásmu v Jílovém u Prahy (Podlaha 1908, 49-50, obr. 58, 59; Čihák, L., Čihák, V. 1948, 32, 48, 69-70 ad.; Šmilauerová, Břicháček 1987, 45, 47). 
V případě Havírny u Štěpánova nad Svratkou nicméně jakékoliv bezprostřední doklady či alespoň nepř́ímé indicie o existenci sakrální stavby v důlním areálu postrádáme, nejsou zachovány ani v mikrotoponymii či místní tradici. Také archeologická prospekce zatím neposkytla jakékoliv příznaky tohoto druhu. Jako vlastní sídlo duchovní správy připadá pro hornický areál na Havírně a jeho obyvatele pro období 13. a 14. století do úvahy zejména nejbližší Štěpánov nad Svratkou s farním kostelem sv. Petra a Pavla; samotná Havírna podnes zůstává součástí štěpánovského územního teritoria. Jako středisko farnosti je Štěpánov v osobě tamního plebána Heřmana doložen poprvé již roku 1285 (CDM IV, 296, č. 226), jádro dnes zachovaného kostela lze datovat do období těsně před nebo kolem poloviny 13. věku (Sadílek 2012, 26-31). Kostel ve Štěpánově přitom podle všeho patřil mezi ty svatyně doubravnického újezdu pánů z Medlova, které na základě donací Štěpána z Medlova a jeho syna Vojtěcha připadly doubravnickému klášteru: opatství alespoň ve 13. století osazovalo tyto fary kněžími spjatými s řeholním životem konventu a prostřednictvím papežských a biskupských privilegií usilovalo o jejich plnou inkorporaci, včetně farních desátků. ${ }^{14}$ Vlastní doly na štěpánovské Havírně jsou položeny vzdušnou čarou jen 2,1km severovýchodně od štěpánovského kostela sv. Petra a Pavla, komunikační trasy umožňovaly vzájemnou dostupnost $\mathrm{v}$ distancích 2,4-3,4 km, tedy do jedné hodiny pěší chůze, v závislosti na výškové náročnosti (obr. 31).

$\mathrm{Z}$ více důvodů je poněkud méně pravděpodobná příslušnost havírenského důlního areálu pod druhou nejbližší stř̌edověkou farní svatyni, sv. Markétu v Prosetíně, 2,4 km severovýchodně. Dobové komunikace sice dovolují uvažovat o trase jen 2,7 km dlouhé, u prosetínského kostela sv. Markéty však především postrádáme jistotu o jeho existenci již ve 13. století: poprvé se zdejší fara v písemných pramenech objevuje roku 1408 (plebán Filip; CDM XIV, 41-42, č. 36). Ze středověkého období tu navíc patrně přetrvala pouze prvá dvě podlaží nyní o samotě stojící subtilní zvonice, jejich bližší časové zařazení však zůstává otázkou (viz Sadílek 2014, 102-109, 140, zvl. 106-107). Prosetín i s patronátem kostela náležel sice nejpozději na konci 14. století také do domény pánů erbu zubří hlavy na horní Svratce, primární vlastník vsi však není jasný (ZDB VII, č. 809, VIII, č. 336, IX, č. 93, XII, č. 588; Wolný 1858, 309; Elbel 2007, 112, 115, 130,

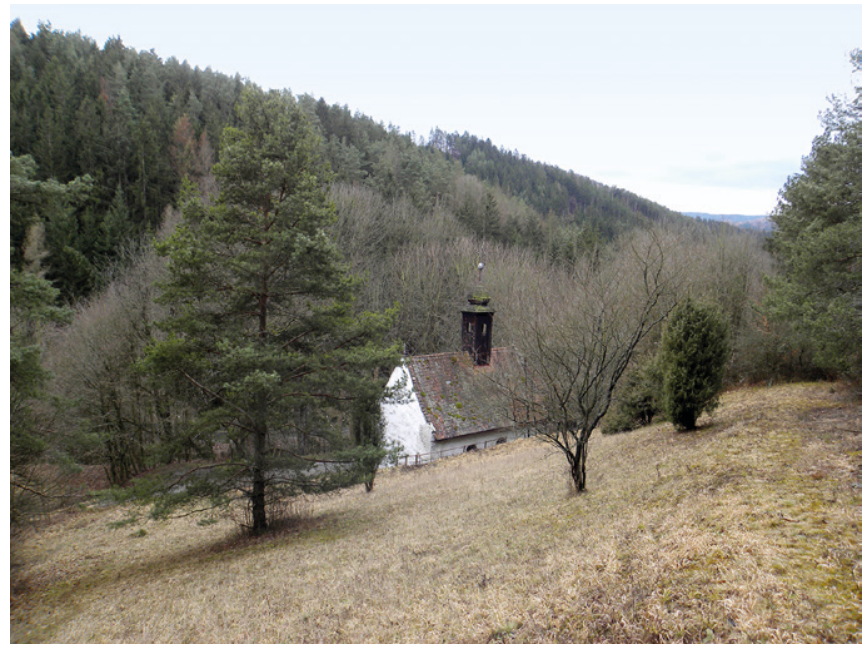

Obr. 32. Švařec, kaple Nejsvětější Trojice od severovýchodu. Foto J. Doležel, únor 2020.

Fig. 32. Švařec, the Chapel of the Holy Trinity from the north-east. Photo by J. Doležel, February 2020. č. 75; srov. Hosák 1938, 323, 324; Sadílek 1996, 41-42, obr. 1; 2014, 20-23, 102-103). Navíc v rámci pernštejnského dominia šlo již o okrajovou lokalitu, do jejíž farnosti tradičně spadaly vsi spíše v odsunutějších polohách této části svrateckého levobřeží (Bolešín, Brt’oví, Čtyři Dvory, později Louka). Pro vazbu Havírny spíše na Štěpánov než na Prosetín hovoří rovněž funkce Štěpánova jako nesporného lokálního ekonomického a správního centra v nejbližším zázemí: bylo tomu tak prokazatelně od 16. století, určitý střediskový význam Štěpánova lze ale předpokládat již ve starších obdobích (Petrlík, Štarha 1979, 393-394, 513, č. 18, tab. LI; Štarha 1985; Jurman 1985, 40-48; 2014, 8-12, 15-18, 60-67, 93; Teplý 1996, 34; 2016, 181-182; Kuča 2008, 316-320).

Předběžně lze proto $\mathrm{v}$ duchovní a církevně-správní sféře počítat s vazbami havírenského důlního areálu i okolních báňských děl 13. a počátku 14. věku nejspíše na farní kostel ve Štěpánově nad Svratkou; existence filiální „hornické“ svatyně př́ímo v rámci důlní lokality zůstává sporná. A priori však nelze ani tuto eventualitu vyloučit, větší jistotu může přinést jen další výzkum. Teoreticky mohl být nevelký sakrální objekt součástí sídelně-správního „ústředí“ve střední partii areálu; vedle (nejspíše dřevěné) kaple ale mohlo jít také o drobný objekt spíše soukromé devoce. Určitou obdobou z období druhého rozmachu těžby stříbra ve štěpánovském rudním revíru v 16. století může být v tomto ohledu kaple Nejsvětější Trojice ve Švařci, hned ve vedlejším údolí, 1,1km severozápadně. Jednoduchá longitudinální architektura postrádá sice po barokizaci zřetelnější znaky starších stavebních fází, poprvé je ale spolu se Švařcem připomínána již v urbáři pernštejnského panství z roku 1591 a při následných prodejích v letech 1596 a 1609 (MZA, F 78, č. 344, fol. 118a, 119a [staré fol. 115a, 116a]; ZDB XXXIII [XXIX], 307-311, č. 5; XXXIV [XXX], 374-375, č. 15; k dataci urbáře srov. Řezníček 2002, 230-232, č. 448). Její vztah k dolování naznačuje jak velmi stará tradice, jednoznačně hovořící o „haviŕrské“ kapli, tak její situování nedaleko od zdejších dobývek, o samotě, 0,4 km severovýchodně od vlastní vsi (Wolný 1858, 375; Tenora 1907, 224-225; $\mathrm{k}$ důlním dílům v okolí kaple viz např. Houzar et al. 2000, 121, č. 6). Právě švařecká svatyně je příznačně v současnosti vnímána také jako nejvýraznější symbol hornické minulosti Štěpánovska (obr. 32); jednoduchý kvadratický půdorys a patrocinium dovolují snad zařadit její vznik do průběhu 16. věku.

\subsubsection{K právnímu základu osídlení na štěpánovské Havírně: význam vyměřené hory a nejhlubší dědičné štoly}

V souvislosti s výkladem o sídelní složce hornického areálu 13. století na Havírně u Štěpánova nad Svratkou je třeba alespoň stručně upozornit na dobový právní rámec, umožňující vznik a existenci jak zdejší hornické osady, tak hornických sídlišt obecně. Rozvinout a zpřesnit zde přitom mohu postřeh Kryštofa Dernera o zřetelné vazbě středověkých hornických sídelních areálů $\mathrm{v}$ českých zemích na tehdy platnou horní legislativu: na prvý pohled zcela zřejmá až banální souvislost totiž jinak nebyla současným bádáním reflektována (srov. Derner 2015, 111, 114, 116; 2017, 130, 132, 135; 2018a, 327-328; Derner, Hrubý 2018, 216, 224, 236; Hrubý et al. 2019a, 879-880).

Středověké horní právo českých zemí 13. století řešilo zřizování právně eximovaných hornických osad př́mo u dolů jak v jasné návaznosti na potřeby rozvinuté perspektivní těžby drahých kovů a tedy i na prospěch panovnického fisku, tak s ohledem na zájmy dotčených pozemkových vrchností. Př́slušné normativy jsou sice dnes v písemné formě $\mathrm{k}$ dispozici teprve ve formulacích mladších kodifikací z konce 13. a počátku 14. věku, jasné indicie jejich aplikace je ale možné sledovat již od 1. poloviny 13. století. Podle ustanovení obou dochovaných mladších latinských zápisů jihlavského horního práva i Ius regale montanorum 
krále Václava II. tak měla mít každá řádně vyměřená důlní míra o sedmi horních lánech právo na zřízení šestnácti svobodných obytných městišt (area, hofstatt, dvořiště). Horní zákoník Václava II. připojil navíc právní nárok na půdu k pasení dobytka okolo takto vyměřeného dolu, jakž daleko jeden člověk s lučištěm mohl by jednú střeliti, tedy v okruhu přibližně 200-260 m (k dostřelu středověkých luků srov. např. Rees 1995; Pratt 2010, 230-231). Ještě šířeji pak privilegovalo Ius regale i tak zvané Německé jihlavské báňské právo tu dědičnou štolu, která by byla ražena nejhlouběji a odvodnila by tak celý širší důlní areál: takovéto horní dílo mělo obdržet tolikrát šestnáct městišřt, kolik by vysušilo příslušných vyměřených sedmilánových dolů (CDB IV. 1, 325, č. 177, čl. IIa; Zycha 1900b, 10 [§ 9], 23 [§ 8], 134-135 [Lib. II, Cap. 3/I, § 1], 156-157 [Lib. II, Cap. 4/V, § 23, 24]; Bretholz 1903, 233 [III], 239 [IV]; Hoffmann ed. 1959, 61, čl. 108; Hoffmann 1981, 57; Bílek ed. 2000a, 44 [Cap. III, § 1], 49 [Cap. IV, § 24]; cf. Zycha 1900a, 180-182). Německé jihlavské horní právo veškerým dědičným štolám nadto přiznávalo totéž na dostřel z luku vymezené teritorium $\mathrm{k}$ pasení dobytka horníků, jako tomu bylo u vyměřených sedmilánových důlních polí (Zycha 1900b, 24, § 12).

Nabízí se otázka, proč právě šestnáct městišť́, vlastních havířských sídelních jednotek, mělo tvořit příslušenství jedné řádně vyměřené „hory“, důlního cechu se všemi náležitostmi. Takto stanovený počet zohledňoval zřejmě více faktorů a hledisek. Jedním z kritérií musela být nesporně průměrná, dlouhodobou praxí a empirií ověřená potřeba určitého počtu pracovních sil, nutných pro zajištění standardního provozu otevřeného vyměřeného dolu. Zřetelná je tu však také vazba na rozdělení důlního majetku na 32 „kapitálových“ podílů a jejich provozní, berní a „obchodovatelné“ násobky ve starém českém horním právu. Právě šestnáctina (sedecimam partem) byla zcela běžnou vlastnickou částí, převáděnou již na počátku 14. století v prosperujících kutnohorských dolech při nejrůznějších obchodních transakcích, například v letech 1308, 1310 a 1311 (Sternberg, Sterly 1837, 62-65, č. 47, 49; RBM II, 937, 959, č. 2 171, 2 207; III, 12, č. 31). Výbava a osazení jednoho městiště při vyměřené hoře tak patrně ekvivalentně odpovídalo dvěma základním majetkovým dílům dolu v období primárního rozmachu exploatace drahých kovů v českých zemích 13. a 14. století a tvořila dobře definovatelnou a převoditelnou majetkovou jednotku (cf. např. Zycha 1900a, 238-252; Kořan 1950, 66-67; 1955, 158-159).

Další pevně stanovené náležitosti svobodných horních či důlních městišt pak blíže specifikovaly některé dochované sentence vrchního jihlavského horního soudu, vynesené na žádost jednotlivých petentů v průběhu 14. a na počátku 15. století. Ojediněle nás o nich zpravují ale i jiné dobové písemnosti, kupř́íladu koncese králů Jana Lucemburského a Karla IV. v záležitostech př́isečnických a brodských dolů z let 1339 a 1351 (Tomaschek ed. 1897, 46-47, 65-66, 101-102, 135-136, č. 84-86, 93, 112, 124; Zycha 1900a, 148-149, 180-183; 1900b, 335-338, č. 27-32; Balášová, Burghardt 2018; Sternberg, Sterly 1837, 87-88, č. 65; CIM II, 574-575, č. 397, pozn. 19; Šmerdová, Beránek edd. 1985, 45, č. 363). Podle těchto dokladů byly součástí výbavy vyměřených hor a privilegovaných štol potřebné počty masných a chlebných lavic (krámců), lázně, výsady volného trhu i výčepu piva, medoviny a vína. Počet masných a chlebných lavic, připadajících na každých přiznaných a vysazených šestnáct městišt přitom nebyl nikterak omezen, mohlo jich být více podle potřeby, zatímco svobodně vysazená lázeň měla na šestnáct areí vycházet jedna (Zycha 1900b, 335-337, č. 27, 29, 30). Jak jihlavská naučení současně zdůrazňovala, $\mathrm{k}$ budování staveb na přidělených a vyměřených důlních městištích byla žádoucí dobrá vůle pozemkového pána; aby se zamezilo nadbytečným škodám neuváženou výstavbou na vrchnostenské půdě, mělo se stavět pouze bezprostředně v rámci příslušného důlního areálu, cechu. Stavebníkům však měl být beze všech překážek zaručen na cech volný přístup i s jejich vozy (Zycha 1900b, 335-337, č. 27-30).

Jako právní podklad pro zřízení trvalejších hornických sídlišt se pro české a moravské rudní revíry z právě probraných ustanovení jeví jako nejdůležitější nárok každé standardně vyměřené důlní míry na šestnáct městišt', za určených podmínek a s okolní půdou $\mathrm{k}$ pastvě na dostřel z luku (shodně již Derner ve výše vzpomenutých citacích). Až rádné vytýčení sedmilánového důlního pole s dalšími přidanými lány po ověření rentability objeveného ložiska, a tedy zahájení vlastní intenzivní exploatace, zakládalo totiž perspektivu stabilního podílu pozemkové vrchnosti na výtěžcích i na výnosech z déle probíhající těžby. Teprve za těchto okolností bylo proto pro pozemkového pána únosné trvalejší usazení většího počtu horníků a havíruo na jeho dominiu, jinak vyňatých z vrchnostenské jurisdikce i ekonomicko-právní podřízenosti a nárokujících si další požitky a potřeby $\mathrm{k}$ dolům, zejména dřevo a vodní zdroje. Nelze samozřejmě vyloučit menší provizorní sídelní objekty či jednotky umístěné u prospekčních nebo nálezných otvírek. Předpokladem pro existenci právně vyňatého hornického sídliště přímo u dolů však bylo vyměření minimálně jednoho „normativního“ důlního pole o rozměrech přibližně $98 \times 64 \mathrm{~m}$, otevřeného nejméně třemi šachtami.

Archeologické poznatky jak ze štěpánovského rudního revíru, tak z dalších montánních regionů tuto premisu zatím potvrzují. Na Štěpánovsku pocházejí archeologicky ověřené relikty středověkého hornického osídlení mimo Havírnu zatím pouze z jediné další lokality, vykazující v rámci revíru znaky standardní těžby v sedmilánové horní míře. Jedná se o důlní areál v lesní trati U Vysoké skály na štěpánovském katastru, 1,4km JJZ Havírny, na odvráceném, jižním úpatí Sokolí hory. Vlastní rudní struktura zde byla exploatována jednak povrchovým výrubem v ostrém srázu, jednak navazující sérií celkem 13 šachet, v pásu o celkové délce přibližně $120 \mathrm{~m}$ (srov. např. Houzar et al. 2000, 117, 131, č. 24, obr. 1: 24; Houzar, Malý 2002, 12, 17, č. 24, obr. 4: 24; Velebil, Kráčmar 2002, 163, 179, č. 24). Práce tu podle nálezu archaického malého havířského želízka probíhaly zřejmě již ve 13. nebo 14. století (Hrazdil et al. 2007, 290, 292, č. 5, obr. 5: 66), patrně soudobé osídlení při západním okraji důlního pole pak indikují relikty zahloubených suterénů obytných objektů a další artefakty získané prospekcí. Obdobně jsou na dobývky o rozloze nejméně jedné plně vyměřené hory vázány prakticky veškeré dosud zjištěné hornické osady v jiných středověkých báňských obvodech, chybějí naopak u průzkumných nebo rozlohou omezených stařin (srov. např. pro české Krušnohoří Derner 2018b).

Ještě vyšší potenciál pro rozmach hornických sídlišt při báňských dílech zřízených podle zásad jihlavského horního práva a Ius regale montanorum skýtalo přednostní postavení nejhlubší dědičné štoly. K ní mohlo být vysazeno šestnáct městišt tolikrát, kolik důlních měr v celém širším montánním areálu odvodňovala. Z podstaty věci šlo o výsadu, která měla podnítit efektivní vysušení co největší části daného horního komplexu v pokročilejší etapě exploatace, po dosažení hlubších, zvodnělých poloh (cf. napřr. Kořan 1950, 27-28; 1955, 123-126, 132-133; Derner et al. 2019, 938-941). Současně stimulovala a podporovala př́liv a usazování pracovních sil potřebných ve fázi maximálního rozpracování ložiska. Spolu s oprávněním jednotlivých důlních polí na zřízení šestnácti městišť vytvářelo toto privilegium široký, byt jistě ne vždy využitý potenciál dynamického růstu hornického osídlení zejména na nejvýznamnějších horních lokalitách.

Tomuto předpokladu odpovídají také dílčí zjištění z některých blíže zkoumaných báňských areálů na Vysočině. V hornickém komplexu Buchberg u Přibyslavi indikovala geomagnetická prospekce, realizovaná na zhruba polovině plochy osídlené dle 
povrchových sběrů, celkem na 85 podpovrchových anomálií, ztotožnitelných zřejmě se suterény jednotlivých obytných objektů. Na lokalitě Štětinka u Vyskytné pak bylo takto zachyceno okolo 120 obdobných příznaků (Derner et al. 2016, 226-227, 237-238, obr. 14, 17, 35, 36; Derner, Hrubý 2018, 217, 219-221, obr. 7, 8; Hrubý 2019, 72-73, 75-77, 169-172, obr. 34, 35, 39, 117, 119; k Buchbergu též Rous 1998, 107-108, 114, obr. 6; 2001, 69, 72, 79-81, obr. 7-9; 2004, 50, 53). Široké uplatnění jako pobídky pro konjunkturální sídelní boom však obě výsady nepochybně nalezly při proslulém „sběhu“ ke Kutné Hoře v poslední čtvrtině 13. století, s desítkami současně zřízených sedmilánových důlních cechů, $\mathrm{s}$ př́íslušnými dědičnými štolami a tomu odpovídajícím početným osídlením na všech stěžejních rudních pásmech; dobrým př́íkladem tu může být výše zmíněná dědičná kuklická štola, roku 1305 již rozrážená do více větví (RBM II, 1 212-1 213, č. 2 773).

V nastíněné perspektivě je proto možné uvažovat o vrchních limitech četnosti osídlení na štěpánovské Havírně. Při teoreticky předpokládaném vytýčení šesti až sedmi úplných důlních měr na lokalitě mohli horníci na jednotlivých havírenských ceších nárokovat v součtu 96 až 112 městišt', právo na zřízení dalšího násobeného množství sídelních jednotek přinášelo sebou efektivní odvodnění jednoho či více důlních polí dědičnou štolou. Za těchto okolností a s přihlédnutím k celkové konfiguraci lokality i možnému vývoji exploatace se jeví opodstatněnou hypotéza o více než pěti desítkách současně osazených městišt při dolech na štěpánovské Havírně. Jejich celkový počet se pak mohl blížit stovce, jistější údaje snad poskytne podrobnější terénní identifikace.

\section{Závěr}

Podrobná plánová dokumentace štěpánovské Havírny jako nejzásadnější výsledek archeologické části projektu let 2017-2019 otevírá možnosti objektivního zhodnocení, ochrany i prezentace této důležité montánní lokality. Předložený text nemůže být $\mathrm{v}$ dané situaci ovšem ničím jiným než výchozí pracovní mezibilancí před dalšími výzkumnými etapami. Inspirující výsledky se staly pobídkou k formulování některých hypotéz i k širší komparaci s poznatky z jiných báňských areálů středověké Evropy, spolehlivější poznatky však může přinést jen pokračující výzkum. Nezbytnou se jeví bližší, již zahájená terénní identifikace veškerých antropogenních reliktů zachycených měřením, stejně jako plošná aplikace geofyzikálních prospekčních metod, jak ve vztahu k sídelní, úpravní a metalurgické složce areálu, tak k vlastním hlubinným důlním dílům (mikrogravimetrie, radar apod.; srov. např. Hrubý 2011, 59-95). Totéž platí také o archeologických odkryvech vybraných nálezových situací, postihujících modelově alespoň základní komponenty funkční struktury lokality.

Př́ítí výzkumné práce však budou realizovány v proměněné situaci. Jak ukázal aktuální vývoj, exaktní zaměření celého areálu se podařilo provést prakticky na samém konci období, nabízejícího ideální podmínky pro terénní dokumentaci. Po omezených, citlivě prováděných těžebních zásazích let 2018 a 2019, likvidujících polomová pole ve východním dílu Havírny, proběhla roku 2020 prakticky na celých dvou severovýchodních tř̌etinách důlního území plošná kalamitní holoseč lesních porostů postižených suchem. Přes kooperaci s pracovníky Lesů České republiky a kontinuální dohled těžební práce poškodily některé partie antropogenního terénního reliéfu, zejména ve srázném severním svahu (k problematice lesního hospodářství ve vztahu k montánním památkám srov. kupř. Hemker 2011, 42-43, obr. 8, 9). Při zvažování možných eventualit přinášela přitom plošná těžba z hlediska uchování lokality menší rizika oproti ponechání oslabených porostů ve stávajícím stavu a jejich trvalém ohrožení rozsáhlými vývraty: jak se ukázalo i ve štěpánovském rudním revíru na průzkumných stařinách nad Hodůnkou na k. ú. Černovic, větry vytvořená vývratová pole nevratně devastují veškeré historické terény. $\mathrm{V}$ této perspektivě nabývá na zásadní důležitosti sladění potř̌eb péče o montánní památky s vhodným režimem lesního hospodářství, stejně jako památková ochrana samotná. ${ }^{15}$

\section{Poděkování}

Př́́spěvek vznikl jako součást Projektu regionální spolupráce Kraje Vysočina a Akademie věd České republiky (identifikační číslo R300011701) „Areál těžby stříbra 13. století Havírna u Štěpánova nad Svratkou - průzkum, dokumentace, prezentace a ochrana“. Tento projekt byl v letech 2017-2019 financován z dotace Akademie věd České republiky a z dotace Kraje Vysočina na základě Smluv o poskytnutí dotace mezi Krajem Vysočina a Archeologickým ústavem AV ČR, Brno, v. v. i., ID O02067.0001 ze dne 7. 4. 2017, ID O02638.0001 ze dne 9. 7.2018 a ID O02831.0001 ze dne 2. 5. 2019.

\section{Poznámky}

1) Cf. kupř. Nováček 1993; Večeřa 1996; 1998; 2004; 2007; 2009a; 2009b; 2017; Večeřa, Večeřová 1999; 2010, 42-44, 47, 51, 57, obr. 54, 56, 57, 65, 74, 84, 85; 2013; Göhler, Wehmayer 2013, 197-200, 204-206, obr. 1, 3, 5, 6; Asrih 2017a, 174-175; 2017b, 68-72; obecně Nováček 2001, 282-284.

2) Ražba štoly Václav na štěpánovské Havírně bývá běžně spojována s ložiskovou prospekcí v 2. polovině padesátých let 20. století (tak např. Houzar et al. 2000, 129, obr. 8; Velebil, Kráčmar 2002, 169, 178; Doležel, Sadílek 2004, 50-52, obr. 5: 1). Př́ístupový terénní zářez štoly, stejně jako západní, stratigraficky starší haldu před jejím ústím, však eviduje již mapa Adolfa Poláka, vyhotovená zřejmě v delším časovém odstupu před započetím těchto průzkumných prací (srov. obr. 4). Navíc i v rukopisech Václava Mátla a Romana Štancla je štola označena jako vyzmáhané staré důlní dílo (Štancl 1980a, prŕíloha č. 9; 1980b, př́loha č. 10). Mohlo by se tedy jednat spíše o štolu, raženou již v sedmdesátých letech 18. věku důlním Janem Kettnerem v rámci aktivit těžařské společnosti, vedené Narstany de Weißem, holštejnsko-limburským knížecím radou a sekretářem (d'Elvert 1866, 252; Polák 1960, 24, 37; srov. např. též Houzar et al. 2000, 129; Houzar, Malý 2002, 8). Na Wolfskronově mapě z roku 1866, byt schématické, je však Zumberger-Stollen zakreslena poněkud dále $\mathrm{k}$ západu, přímo při zakončení severního pásma obvalů (obr. 3). Její poloha tak odpovídá spíše ústí předpokládané středověké dědičné štoly (ta mohla být v 18. století pouze vyzmáhána a prodloužena), zatímco v místě štoly Václav mapa žádný otevřený horizontální báňský objekt neeviduje (Wolfskron 1889, 236, tab. V, obr. 1). Štola Václav proto může souviset i s dalšími, pozdějšími etapami ověřování a průzkumu horních stařin štěpánovského rudního revíru: dobu jejího vzniku snad spolehlivěji objasní další archivní průzkum.

3) Metodicky kupř. Asrih 2013; Falke 2013; Lissek, Holešinský 2014; Pacina, Brůna 2014; Heynowski 2014; z celé řady jednotlivých aplikací v rámci Evropy namátkou alespoň Casagrande 2013; Schwabenicky 2014, 165, 167, obr. 2, 6; Ernée et al. 2014, 91-102, obr. 4, 5, 7, 14, 16, 21, 23, 25, 28; Cembrzyński, Legut-Pintal 2014; Zeiler et al. 2015, 55-56, obr. 2; Legut-Pintal et al. 2017; Maciejak et al. 2017, 46-48, 53-54, obr. 2, 4, 11; Hrubý 2019, 54-59, 72-75, 98, obr. 18, 20, 23, 34, 36,62 . Širší interpretační možnost metody demonstrovali kupř. Haupt et al. 2013; výstižně její potenciál v oboru montánní archeologie glosoval Hrubý 2014b. 
4) Souhrnně ke zkoumaným horním a hutnickým areálům evropského středověku např. Bailly-Maître 2002, 53-144, 170-174; Derner et al. 2016, 218-230, 235-239; Hrubý 2019, 67-193; souborné publikace jednotlivých lokalit přinášejí výběrově kupř. Dahm et al. 1998; Steuer ed. 1999; Spiong 1999; Goldenberg, Fröhlich 2006; Cech 2007; Schwabenicky 2009, 10-203; Holdermann 2011; 2015a; Hrubý 2011; Hrubý et al. 2012a; Krause 2013; Hofmann, Wolkersdorfer 2013; Derner 2018a; Hrubý et al. 2019b. K fenoménu hornických sídlišt srov. např. Nováček 1994; Hrubý 2019, 166-181; Crkal et al. 2019; Hrubý et al. 2019a, 879-886.

5) Srov. Bailly-Maître, Bruno-Dupraz 1994, 51-89; Bailly-Maître 2002, 12-15, 44-48, 60-72, 81-83, 98-118, tab. XI-XIII, XV-XVII, obr. 20-31, 43-47, 57-64, 67-73; Weisgerber 1998, 133-199; Zeiler et al. 2015, 56-65, 71, obr. 4, 6-21; Meyerdirks 2007, 5-6, obr. 6; Goldenberg, Steuer 1998, 203-205, obr. 8-13; 2004, 56-63; Brunn, Maass 1999; Scholz 2011; 2013; Hemker 2013; Hönig, Lentzsch 2014; Schröder 2015; 2018, 31-54.

6) Viz jednotlivé komentáře, jak je podávají kupř. Čelakovský 1897, 618, 620-621; 1900, 266-272; Zycha 1900a, 217-224; Leminger 1929, 753; Weizsäcker 1929, 139; Kořan 1950, 65-66; 1955, 79-80; 123; 1974, 217; 1988, 28, 31, 44; Vosáhlo 1996, 33-38, 42, 43; Bílek ed. 2000a, 41, pozn. 105; 2002, 26; Večeřa 2007, 71-74; 2009a; 2009b; 2013; Balášová, Burghardt 2014, 130, 132 .

7) Srovnání nabízejí kupř. Večeřa 1996; 1998; 2004; 2007; 2009a; 2009b; 2013; Večeřa, Večeřová 1999; 2010, 42-44, 47, 51,57 , obr. 54, 56, 57, 65, 74, 84, 85; Večeřová, Večeřa 2013; Hrubý 2016, 188, obr. 6; 2019, 77, 81, 84-89, obr. 39, 42, 53; souhrnně kriticky Asrih 2017a, 174-175; 2017b, 68-72.

8) Ke všem právě uvedeným důlním lokalitám souhrnně Houzar et al. 2000, 117, 119, 122-123, 125-127, 131-133, č. 2, 10, 16, 24, 27, obr. 1, 6, 10; 2001, 23, 29, obr. 4a; Houzar, Malý 2002, 11-14, 17, 18, č. 2, 10, 16, 24, 27, obr. 4, 9; Velebil, Kráčmar 2002, 163, 175-177, 179; Sikora 2010. K získaným archeologickým nálezům havířských nástrojů z těchto stařin Hrazdil et al. 2007, 285, 286, 291, 292, obr. 2, 3, 5, č. 77-79, 80, 83.

9) Viz Goš et al. 1985, 194-197, obr. 2, 3; Rous et al. 2004; Hrubý et al. 2010, 76-78, 81-95, obr. 2, 3, 5, 11-43; 2012a, 342-344, 350-377, 405, 409-410, obr. 5-7, 14-75; 2019b; Hrubý 2017, 9-12, obr. 18-21; 2019, 92-136, obr. 57-101. Šíŕeji k problematice vodních zdrojů ve stř̌edověkých hornicko-hutnických areálech kupř. Hrubý et al. 2014, 206-207; Hrubý 2019, 200-201.

10) CDB III.1, 82-83, č. 76. Souhrnně, s další literaturou k problematice střredověkých hornických společenství a jejich sídel kupř. Paulinyi 1966, zvl. 44-49, 291-312; Bartels, Klappauf 2012, 217-230; Derner 2017, 9-17, 127-156; Derner, Hrubý 2018; Hrubý et al. 2019a; diskusně i diskutabilně Graulau 2018; 2019a, 596-605; 2019b, 73-137, 148-160.

11) K vyjmenovaným př́padům srov. Zimmermann 1993, 213-217, obr. 9, 11; Goldenberg, Steuer 1998, 201-203, obr. 7; Steuer, Goldenberg 2002, 406-411, obr. 2, 7; Gechter 2003, 157-160, obr. 1, 2, tab. 2; Pichler 2003, např. 142-143, obr. 128; Goldenberg, Fröhlich 2006; Cech 2007, 17-89, př́loha; Strassburger 2012, 34-35, obr. 4; Hilber 2012; Kvietok 2014, 3-7, 10-11, 14, 15, obr. 2, 5, 6.

12) Na místě je tu možné uvést kupříkladu archeologicky zkoumané lokality Altenberg v Siegerlandu, Sulzburg/Geißmättle a Birkenberg ve Schwarzwaldu či Zellerfeld v Harzu (Zimmermann 1993, 213-217, obr. 9, 11; Lobbedey et al. 1998, 21-132, plány 1-5, zvl. 22-31, 38, obr. 5; Spiong 1999, 68-73, 78-82, obr. 2-4, 9, 10; Steuer, Goldenberg 2002, 406-421, obr. 2, 4-8; Alper 2003, 102-172, prŕíloha 4). Celá řada jednotlivých segmentů nebo širších ploch montánních sídliš̌t byla odkryta v Sasku, v širším freiberském rudním revíru, jde o areály Dippoldiswalde/Roter Hirsch, Freiberg/Kaufhausgasse, Rammelsberg a Untergasse, dále Fürstenberg/ Hohenforst, Neuhilbersdorf, Schönborn-Dreiwerden/Biege, Treppenhauer nebo Ullersberg u Wolkenburgu (Richter 1994, 119-121, obr. 11, 12, 16; Schwabenicky 2009, 12-18, 21-22, 34-78, 179-202, 226-232, obr. 6-11, 18, 354-356, 382, 386-393; Kenzler 2009, 268-269, 272-274, 276-279, 289-294, obr. 4, 8, 11-13, 21, 22; Hoffmann, Richter 2012, 160-163, 207-208, obr. 90-96, 143; Richter 2013, 369-372, obr. 2-7; Wegner, Schubert 2015, 208-216, obr. 2, 3, 8-14). Na české straně Krušnohoří pocházejí cenné poznatky zejména ze sídliště Kremsiger u bývalé Př́sečnice (Derner 2015, 111-117, obr. 5-9; 2017, 48-62, 228-239, obr. 38-58; 2018a, 228, 242-257, 316-324, 327-329, obr. 125, 148-183, 249-259; Derner, Hrubý 2018, 226-228, obr. 15; Crkal et al. 2019, 900, 902-917, obr. 21-31). Četné shodné situace byly zaznamenány také na Českomoravské vrchovině, na lokalitách Černov/Chrástov/Cvilínek, Česká Bělá, Jihlava/Staré Hory, Květinov nebo Termesivy/U Zelingrů (Rous 1996, 78, 80-83, tab. 1, 2; 1998, 102-105, 110-111, 113, obr. 1, 2, 5; Hrubý et al. 2007, 24-35, obr. 7-17; Hrubý 2011, 148-184, 242-245, příloha; Hrubý et al. 2012a, 381-385, 407, obr. 78-82; 2012b, 148-151, 154, obr. 4, 10-12; 2014, 69-84, 98-106, obr. 45, 48, 49, 65-70; Derner, Hrubý 2018, 218-219, 222-228, obr. 5, 6, 11-14; Crkal et al. 2019, 896-903, obr. 8-17). Obraz pak v př́ípadě českých zemí dokreslují jednotlivá zjištění z obecně známých hornických středověkých center Kutná Hora, Jílové, Kašperské Hory či Zlaté Hory/Altenberg (Šmilauerová, Břicháček 1987, 32, 42, 44, obr. příloha 3; Waldhauser et al. 1993; Valentová 1999; Brachtl, Večeřa 1999; Večeřa, Večeřová 2007; Velímský 2007, 96, obr. 7; 2012, 206-209, obr. 9; 2017, 22-23, 28-29, obr. 12, 14,15 ; Večeřa 2013, 50-51, obr. 10). Souhrnně k fenoménu aplikované zástavby hornických osad evropského středověku kupř. Schwabenicky 2011, 17-22; Kenzler 2012, 153-164, 192-197, obr. 137, 138; Derner 2015, 114-117; 2017, 136-147; 2018a, 319-324; Derner, Hrubý 2018, 222-228, obr. 11-15; Hrubý 2019, 176-181; Crkal et al. 2019, 891-917.

13) Cf. Ottenthal, Redlich 1896, 345, 347, č. 1 686, 1 694, 1 696, 1 698; Andergassen 2000, 199; Holdermann 2015a; Torggler 2019a, 24-31; 2019b, 158-164; resp. Burmeister 2003; Scheibenstock 2004; Krause 2013, 2-9, 29, obr. 2, 3, 6, 8, 9; Neuhauser 2013, 33-39, obr. 4, 5, 7, 8, 10; Hofmann, Wolkersdorfer 2013, 32-35, 47-51, 107, obr. 9, 10; Krause et al. 2015. Velmi obsáhlé informace o dějinách kostelů a kaplí v montafonském rudním revíru ve 14.-16. věku podávají listiny, v hojném počtu dochované $\mathrm{v}$ archivech farností Bartholomäberg a zejména Silbertal, zpřístupněné prostřednictvím virtuálního archivu Monasterium.net. Srov. Vorarlberger Landesarchiv Bregenz, fond Bartholomäberg, Pfarrarchiv, č. 315, 325, 340; fond Silberberg, Pfarrarchiv, č. 431-433, 437, 445, 450, $453,455,456,464,465,470,475,477,478,482,491-506$, $508-510,512,515,519,520,523,525,527,530,533,535$ a dále; viz též MON-CA-B; MON-CA-S.

14) CDB III.1, 147-149, 232-233, č. 119, 186; III.3, 384-386, 410-411, č. 269, 292; CDM V, 82-83, 163-164, č. 82, 155; VI, 113, č. 142. Srov. např. Štarha 1980, 21-23; 2004, 39-42; Sedláček 1992, 37-46; 2000, 8-11; Teplý 1996, 3-28, 36-37, 48-49, 65-66, 79-82; 2016, 73-74; Vorel 1999, 16-35; Sadílek 2008, 63-74.

15) Závěrečné poděkování náleží všem, kteří byli jakkoliv nápomocni při realizaci samotných projektových prací i při vzniku tohoto textu. Vlastním tvůrčím iniciátorem projektu i př́větivým, velkorysým společníkem a spoluřešitelem v jeho tř́letém 
trvání byl RNDr. Karel Malý, Ph.D., z Muzea Vysočiny v Jihlavě. Velmi vstřícný př́stup, opakovanou finanční podporu i osobní zajem naleznul projekt ze strany Akademie věd České republiky i Kraje Vysočina: je tu třeba jmenovat zejména PhDr. Tatánu Petrasovou, CSc., členku Akademické rady AV ČR, hejtmana Kraje Vysočina MUDr. Jiřího Běhounka a vedoucí Odboru regionálního rozvoje Krajského úřadu Kraje Vysočina, doc. RNDr. Ivetu Fryšovou, Ph.D. Samotných dokumentačních prací se ochotně ujal Ing. Miloš Tejkal. Excerpci některých titulů odborné literatury laskavě umožnili kolegové ze Archaia Brno, z. ú., pobočka Jihlava, Petr Duffek, Mgr. Šimon Kochan a Mgr. Jakub Těsnohlídek, stejně jako doc. Mgr. Petr Hrubý, Ph.D., z Ústavu archeologie a muzeologie Filosofické fakulty Masarykovy univerzity, zasvěceně také konzultující problematiku z perspektivy vlastních poznatků z oblasti Českomoravské vrchoviny i širší Evropy. Totéž platí rovněž o RNDr. Stanislavu Houzarovi, Ph.D., z Mineralogicko-petrografického oddělení Moravského zemského muzea v Brně, který navíc vstřícně zpř́ístupnil některé v muzeu deponované části pozůstalosti Adolfa Poláka. Inspirativní byla diskuse nad plánem Havírny s RNDr. Josefem Večeřou z České geologické služby, pracoviště Jeseník, stejně jako hovory i cesty s kolegy ze samotného Archeologického ústavu AV ČR, Brno, v. v. i., PhDr. Rudolfem Procházkou, CSc., a Mgr. Petrem Žákovským, Ph.D. Velmi přínosné podněty $\mathrm{k}$ více aspektům vypracovaného textu pak přinesl MUDr. et Mgr. Kryštof Derner z Ústavu archeologické památkové péče severozápadních Čech, v. v. i. Cenné informace k Havírně i jiným lokalitám poskytnul znalec štěpánovského rudního revíru, Jaroslav Sadílek z Bystřice nad Pernštejnem, staré fotografie Štěpánova nad Svratkou pak starostka městyse, Paedr. Šárka Kunčíková a Petr Skokan. Prací při úpravách části obrazového aparátu se nakonec aktivně a invenčně ujala Ing. Lenka Zahradníková.

\section{Prameny a literatura}

Agricola, G. 1556: Georgii Agricolae De re metallica libri XII. Basileae: Hieronymus Frobenius et Nicolaus Episcopus.

Alper, G. 2003: „Johanneser Kurhaus“. Ein mittelalterlicher Blei-/ Silbergewinnungsplatz bei Clausthal-Zellerfeld im Oberharz. Rahden/ Westf.: Verlag Marie Leidorf GmbH.

Andergassen, L. 2000: Südtirol. Kunst vor Ort. Bozen: Athesia.

Asrih, L. 2013: Airborne laser scans as a tool for historical science? First methodic considerations using the example of medieval mining in the Saxon Ore Mountains (Erzgebirge/Germany). In: P. Anreiter et al. (eds.): Mining in European History and its impact on Environment and Human Societies: Proceedings for the $2^{\text {nd }}$ Mining in European History Conference of the FZ HiMAT. Innsbruck, 7. - 10. November 2012. Innsbruck: Innsbruck University Press, 229-234.

Asrih, L. 2017a: Aktualität und Praktikabilität des Freiberger Bergrechts vom 12. bis ins 14. Jahrhundert. Der Anschnitt 69(3-4), 166-180.

Asrih, L. 2017b: „Das synt gemeyne bergrecht ...“. Inhalte und Anwendung des Freiberger Bergrechts im Mittelalter. Bochum: Verlag Marie Leidorf $\mathrm{GmbH}$.

Bailly-Maître, M.-Ch. 2002: L'argent. Du minerai au pouvoir dans la France médiévale. Paris: A. \& J. Picard.

Bailly-Maître, M.-Ch. 2010: Extraction et traitement d'un minerai d'argent au Moyen Âge (XII $-\mathrm{XIV}^{\mathrm{e}}$ siècle). ArcheoSciences. Revue d'archéométrie 34, 221-233.

Bailly-Maître, M.-Ch., Bruno-Dupraz, J. 1994: Brandes-en-Oisans. La mine d' argent des Dauphins (XIIe-XIVe siècles), Isère. Lyon: Alpara.
Balášová, M., Burghardt, I. 2014: Das böhmische und das sächsisch-meißnische Bergrecht im Mittelalter. České a sasko-míšeňské horní právo ve středověku. In: R. Smolnik (ed.): Silberrausch und Berggeschrey. Archäologie des mittelalterlichen Bergbaus in Sachsen und Böhmen. Stř́ibrná horečka a volání hor. Archeologie středověkého hornictví v Sasku a Čechách. Dresden: Verlag Beier \& Beran, 125-132.

Balášová, M., Burghardt, I. 2018: Neznámá listina z roku 1339 jako nejstarší písemný doklad o těžbě stříbra v českém Krušnohoří. Eine unbekannte Urkunde aus dem Jahr 1339 als ältester schriftlicher Nachweis von Silberbergbau im böhmischen Erzgebirge. In: K. Derner et al.: Středověké hornictví a hutnictví na Př́sečnicku ve středním Krušnohoří. Mittelalterlicher Bergbau und Hüttenwesen in der Region Preßnitz im mittleren Erzgebirge. Dresden: Landesamt für Archäologie Sachsen, 415-427.

Bartels, Ch., Klappauf, L. 2012: Der Aufschwung des Bergbaus unter den karolingischen und ottonischen Herrschern, die mittelalterliche Blüte und der Abschwung bis zur Mitte des 14. Jahrhunderts. In: Ch. Bartels, R. Slotta (eds): Geschichte des deutschen Bergbaus. Band 1: Der alteuropäische Bergbau. Von den Anfängen bis zur Mitte des 18. Jahrhunderts. Münster: Aschendorff Verlag, 111-248.

Bartoš, M. 2004: Stř̌edověké dobývání v Kutné Hoře. In: K. Nováček (ed.): Těžba a zpracování drahých kovũ: sídelní a technologické aspekty. Mediaevalia archaeologica 6. Praha, Brno, Plzeň: Archeologický ústav AV ČR Praha, Archeologický ústav AV ČR Brno, Západočeská univerzita v Plzni, 157-201.

Bílek, J. (ed.) 2000a: Ius regale montanorum aneb Právo královské horníkuov. Kutná Hora: Martin Bartoš - Kuttna.

Bílek, J. 2000b: Kutnohorské dolování. 1. Grejfské žilné pásmo. Kutná Hora: Martin Bartoš - Kuttna.

Bílek, J. 2000c: Kutnohorské dolování. 2. Roveňské žilné pásmo. Kutná Hora: Martin Bartoš - Kuttna.

Bílek, J. 2000d: Kutnohorské dolování. 3. Kuklické žilné pásmo. Kutná Hora: Martin Bartoš - Kuttna.

Bílek, J. 2002: Nad mezinárodní konferencí k 700. výročí IRM a měnové reformy krále Václava II. Kutnohorsko. Vlastivědný sborník 6/2002, 16-50.

Brachtl, Z., Večeřa, J. 1999: Terénní archeologický průzkum středověkých důlních děl na Zlatohorsku (okr. Jeseník). Přehled výzkumu 39 (1995-1996), 518-520.

Bretholz, B. 1903: Johannes von Gelnhausen. Kritisch-historische Studie mit zwei Anhängen: 1. Unedierte Iglauer Rechtssprüche für Kuttenberg, 2. Johanns von Gelnhausen „Deutsches Bergrechtsbuch“. Zeitschrift des deutschen Vereines für die Geschichte Mährens und Schlesiens VII(1-2), 205-281.

Brůna, V., Pacina, J. 2014: Role geotechnologií v montánní archeologii. Die Rolle von Geotechnologien in der Montanarchäologie. In: R. Smolnik (ed.): ArcheoMontan 2013. Krušná krajina - Erz(gebirgs) landschaft - Ore Landscape. Mezinárodní konference. Kadaň, 26. až 28. zár̆í 2013. Internationale Fachtagung. Kadan̆ 26. bis 28. September 2013. Dresden: Landesamt für Archäologie Sachsen, 31-42.

Brunn, A., Maass, A. 1999: Archäologische Ausgrabungen an und in den alten Bergwerken auf dem Riestergang in Sulzburg. Archäologische Nachrichten aus Baden 61/62, 23-35.

Burmeister, K. H. 2003: Zwei illuminierte Ablassbriefe für die Kapelle im Montafon von 1332 und die Kirche in Höchst von 1333. Bludenzer Geschichtsblätter 69, 3-13.

Casagrande, L. 2013: Mining landscape in the Province of Trento (north-east Italy): new technologies for research and preservation. In: R. Smolnik (ed.): ArcheoMontan 2012. ErkundenErfassen - Erforschen. Internationale Fachtagung Dippoldiswalde 18. bis 20. Oktober 2012. Prüzkum - Evidence - Interpretace. Mezinárodní konference Dippoldiswalde, 18. až 20. ř́ijen 2012. Dresden: Landesamt für Archäologie, 39-43. 
CDB III.1: Codex diplomaticus et epistolaris regni Bohemiae. Tomi III fasciculus primus inde ab a. MCCXXXI. usque ad a. MCCXXXVIII. Ed. G. Friedrich. Pragae 1942: Sumptibus Terrae Bohemiae.

CDB III.3: Codex diplomaticus et epistolaris regni Bohemiae. Tomi III fasciculus tertius acta spuria et additamenta inde ab anno MCCXXXI usque ad annum MCCXL. Edd. G. Friedrich, Z. Kristen, J. Bistřický. Olomucii 2000: Universitas Palackiana Olomucensis.

CDB IV.1: Codex diplomaticus et epistolaris regni Bohemiae. Tomi IV fasciculus primus inde ab a. MCCXLI. usque ad a. MCCLIII. Edd. J. Šebánek, S. Dušková. Pragae 1962: Sumptibus Academiae scientiarum Bohemoslovenicae.

CDB V.2: Codex diplomaticus et epistolaris regni Bohemiae. Tomi $\mathrm{V}$ fasciculus secundus inde ab a. MCCLXVII usque ad a. MCCLXXVIII. Edd. J. Šebánek, S. Dušková. Pragae 1981: Sumptibus Academiae scientiarum Bohemoslovacae.

CDM IV: Codex diplomaticus et epistolaris Moraviae. IV. (1268-1293). Ed. A. Boczek. Olomucii 1845: Ex typographia Aloysii Skarnitzl.

CDM V: Codex diplomaticus et epistolaris Moraviae. V. (1294-1306). Edd. A. Boczek, J. Chytil. Brunae 1850: Auspiciis nec non impensis Marchionatus Moraviae.

CDM VI: Codex diplomaticus et epistolaris Moraviae. VI. (1307-1333). Edd. P. R. v. Chlumecky, J. Chytil. Brünn 1854: im Auftrage des mährischen Landes-Ausschusses.

CDM XIV: Codex diplomaticus et epistolaris Moraviae. XIV. (14081411). Ed. B. Bretholz.Brünn 1903: im Auftrage des mährischen Landesausschusses.

Cech, B. 2007: Spätmittelalterliche bis frühneuzeitliche Edelmetallgewinnung in den Hohen Tauern. Montanarchäologische Forschungen im Bockhartrevier, Gasteiner Tal (Bundesland Salzburg). Teil 1, 2. Mainz: Verlag des Römisch-Germanischen Zentralmuseums.

Cembrzyński, P., Legut-Pintal, M. 2014: Airborne laser scanning as a method of localisation and documentation of mining sites remains. Examples from Silesia. Acta rerum naturalium. Př́rodovědný časopis Vysočiny. Stř́brná Jihlava 2013 16, 187-201.

CIM II: Codex juris municipalis regni Bohemiae. Tomus II. Privilegia regalium civitatum provincialium annorum 1225-1419. Sbirka pramenů práva městského Království českého. Díl II. Privilegia královských měst venkovských z let 1225-1418. Ed. J. Čelakovský. Praha 1895: Česká akademie císaře Františka Josefa pro vědy, slovesnost a umění v Praze, Fond pro vydávání pramenů práva městského Království českého.

Crkal, J., Derner, K., Hrubý, P., Milo, P. 2019: Architektura hornických sídlišt na sklonku přemyslovské doby. Archaeologia historica 44(2), 887-923.

Čelakovský, J. 1897: Horní právo. In: J. Otto (ed.): Ottův slovník naučný. Jedenáctý díl. Praha: J. Otto, 615-627.

Čelakovský, J. 1900: Nástin dějin českého práva horního. In: J. Čelakovský: České dějiny právní. Druhé doplněné vydání dle Ottova slovníku naučného. Praha: Bursík \& Kohout, 264-292.

Čelakovský, J. 1916: Klášter Sedlecký, jeho statky a práva v době před válkami husitskými. K vydání připravil V. Vojtíšek. Praha: Česká akademie císaře Františka Josefa pro vědy, slovesnost a umění.

Čihák, L., Čihák, V. 1948: Paměti královského horního města Jílového a jeho zlatých dolu. Praha: Okresní museum v Jílovém.

Dahm, C., Lobbedey, U., Weisgerber, G. 1998: Der Altenberg. Bergwerk und Siedlung aus dem 13. Jahrhundert im Siegerland. Band 1: Die Befunde. Band 2: Die Funde. Bonn: Dr. Rudolf Habelt GmbH.

Derner, K. 2015: Kremsiger in the Ore Mountains: a mining settlement, or a town? - Reflections on the urban character of mining settlements. In: J. Silvertant (ed.): Mining archaeology. Perspectives, conflicts, challenges. 10th International Symposium on archaeological Mining History. Eichach, Gulpen: Institute Europa Subterranea Valkenburg aan de Geul, 106-129.
Derner, K. 2017: Vrcholně středověká hornická sídliště se zvláštním zřetelem k lokalitě Kremsiger (k. ú. Přísečnice) [online]. Rkp. diplomové práce. Praha: Univerzita Karlova. Filozofická fakulta. Ústav archeologie. Uloženo: Repozitář závěrečných prací Univerzity Karlovy. [cit. 2020-10-30]. Dostupné z: https://is.cuni.cz/ webapps/zzp/detail/137011/.

Derner, K. 2018a: Hornické sídliště na Kremsigeru. Die Bergbausiedlung auf Kremsiger. In: K. Derner et al.: Středověké hornictví a hutnictví na Př́sečnicku ve středním Krušnohoří. Mittelalterlicher Bergbau und Hüttenwesen in der Region Preßnitz im mittleren Erzgebirge. Dresden: Landesamt für Archäologie Sachsen, 217-379.

Derner, K. 2018b: Skutečná nebo zdánlivá absence dalších hornických sídlišt? Tatsächliche oder scheinbare Absenz weiterer Bergbausiedlungen? In: K. Derner et al: Středověké hornictví a hutnictví na Př́sečnicku ve středním Krušnohoří. Mittelalterlicher Bergbau und Hüttenwesen in der Region Preßnitz im mittleren Erzgebirge. Dresden: Landesamt für Archäologie Sachsen, 387, 392-393.

Derner, K., Hrubý, P. 2018: Otázka zemědělství a potravinářské produkce středověkých hornických komunit. Archaeologia historica 43(1), 207-239.

Derner, K., Hrubý, P., Malina, O., Večeřa, J. 2019: Hornické revíry vrcholného středověku a raného novověku ve srovnávacím pohledu. Archaeologia historica 44(2), 925-947.

Derner, K., Hrubý, P., Schubert, M. 2016: Mittelalterliche Silberproduktion im wettinischen und přemyslidischen Regierungsraum: Neue archäologische Untersuchungen. Der Anschnitt 68(6), 216-241.

Doležel, J. 2002: Goblinus et Iohannes de Iglavia. Několik poznámek ke dvěma osobám brněnských dějin 13. a 14. století a jejich roli v důlním podnikání. Brno v minulosti a dnes XVI, 33-49.

Doležel, J. 2008: Středověká miskovitá (lotová) závaží v českých a moravských nálezech. Přehled výzkumů 49, 183-215.

Doležel, J. v tisku: Švařec (okr. Žd'ár nad Sázavou). Přrehled výzkumů 62(2), 2021, v tisku.

Doležel, J., Kejzlar, M. 2013: Nové poznatky o důlním komplexu Havírna u Štěpánova nad Svratkou: výsledky povrchového prüzkumu $v$ letech 2002-2012. Referát. XLV. mezinárodní konference archeologie středověku České a Slovenské republiky na téma Zdroje a zpracování surovin v archeologii středověku, Kutná Hora, 16. 9. 2013.

Doležel J., Sadílek, J. 2004: Středověký důlní komplex v trati Havírna u Štěpánova nad Svratkou. Př́íspěvek k dějinám těžby stříbra v oblasti severozápadní Moravy ve 13. a 14. století. I. Výsledky průzkumu v letech 1990-2001, edice písemných pramenů. In: K. Nováček (ed.): Těžba a zpracování drahých kovi̊: sídelní a technologické aspekty. Mediaevalia archaeologica 6. Praha, Brno, Plzeň: Archeologický ústav AV ČR Praha, Archeologický ústav AV ČR Brno, Západočeská univerzita v Plzni, 43-119.

Elbel, P. 2007: Zlomek olomoucké konfirmační knihy z let 1452-1455. Předběžné výsledky rozboru opomíjeného pramene k poznání církevní topografie, diecézní správy a konfesního soužití na Moravě po polovině 15 . století. In: J. Hrdina, B. Zilynská (eds.): Církevni topografie a farní sít pražské církevní provincie v pozdním středověku. Colloquia mediaevalia Pragensia. 8. Praha: Filosofia, 91-137.

d'Elvert, Ch. 1866: Zur Geschichte des Bergbaues in Mähren und Oesterr.-Schlesien. In: Ch. d'Elvert: Zur Cultur-Geschichte Mährens und Oest. Schlesiens. I. Theil. Bildet den 15. Band der Schriften der historisch-statistischen Sektion der k. k. m. s. Gesellschaft zur Beförderung des Ackerbaues, der Natur- und Landeskunde. Brünn: Verlag der histor. statist. Sektion, in Commission der Buchhandlung A. Nitsch, 97-534. 
Ernée, M., Hrubý, P., Malý, K., Tomášek, M., Valkony, J. 2014: Raná exploatace exogenních akumulací zlata na Českokrumlovsku. Acta rerum naturalium. Př́ŕrodovědný časopis Vysočiny. Stř́brná Jihlava 2013 16, 85-108.

Falke, D. 2013: Archäologische Fernerkundung von obertätigen Bergbauspuren mithilfe von Airborne Laserscanning. Archeologický průzkum povrchových stop hornické činnosti pomocí leteckého laserového skenování. In: R. Smolnik (ed.): ArcheoMontan 2012. Erkunden - Erfassen - Erforschen. Internationale Fachtagung Dippoldiswalde 18. bis 20. Oktober 2012. Průzkum - Evidence - Interpretace. Mezinárodni konference Dippoldiswalde, 18. až 20. ř́ijen 2012. Dresden: Landesamt für Archäologie Sachsen, 19-29.

Flodr, M. (ed.) 1990: Právní kniha města Brna z poloviny 14. století. I. Úvod a edice. Brno: Archiv města Brna.

Flodr, M. (ed.) 2005: Pamětní kniha města Brna z let 1343-1376 (1379). Brno: Matice moravská.

Fröhlich, J. 1993: Ruční mlýny na rozemílání zlaté rudy na Kometě. Studie z dějin hornictví 22, 7-23.

Fröhlich, J. 2006: Zlato na Prácheňsku. Kapitoly z historie těžby a zpracování zlata. Písek: Prácheňské nakladatelství.

Fröhlich, J. 2012: Stoupové a mlýnské kameny z rudných úpraven v Evropě. Acta rerum naturalium. Př́rodovědný časopis Vysočiny. Stříbrná Jihlava 2010 12, 119-125.

Fröhlich, J. 2017: Stř̌edověké a raně novověké mlýny na zlatou rudu v Čechách. Zlatá stezka 24, 205-219.

Fröhlich, J. 2019: Zlatodoly v Píseckých horách. Přehled současného stavu archeologického poznání. Archeologie ve středních Čechách 23, 617-627.

Gája, R. 2016: Vývoj farní sitě v kontextu dějin osídlení [online]. Rkp. disertační práce. Praha: Univerzita Karlova. Filozofická fakulta. Ústav českých dějin. Uloženo: Digitální repozitář Univerzity Karlovy. [cit. 2020-10-30]. Dostupné z: https://dspace.cuni.cz/ handle/20.500.11956/83796.

Gechter, M. 2003: Das Bleibergwerk Silberkaule, Gemeinde Engelskirchen, Rheinisch-Bergischer Kreis. In: T. Stöllner, G. Körlin, G. Steffens, J. Cierny (eds.): Man and Mining Mensch und Bergbau. Studies in honour of Gerd Weisgerber on occasion of his $65^{\text {th }}$ birthday. Bochum: Deutsches Bergbau-Museum, 155-161.

Göhler, M., Wehmeyer, M. 2013: Montanarchäologische Kartierungen. Montánněarcheologické mapování. In: R. Smolnik (ed.): ArcheoMontan 2012. Erkunden - Erfassen - Erforschen. Internationale Fachtagung Dippoldiswalde 18. bis 20. Oktober 2012. Průzkum - Evidence - Interpretace. Mezinárodní konference Dippoldiswalde, 18. až20. ř́ijen 2012. Dresden: Landesamt für Archäologie, 197-208.

Gojda, M. 2017: Archeologie a dálkový priozkum. Historie, metody, prameny. Praha: Academia.

Goldenberg, G., Fröhlich, M. 2006: Der Birkenberg bei Bollschweil-St. Ulrich. Ein Bergbaurevier aus dem Mittelalter. Bollschweil: Freundeskreis „Burg und Bergbau - die Birchiburg in Bollschweil e.V.“.

Goldenberg, G., Steuer, H. 1998: Montanarchäologische Forschungen im Südschwarzwald. Denkmalpflege in Baden-Württemberg. Nachrichtenblatt der Landesdenkmalpflege 27(4), 197-205.

Goldenberg, G., Steuer, H. 2004: Mittelalterlicher Silberbergbau im Südschwarzwald. In: G. Markl, S. Lorenz (eds.): Silber, Kupfer, Kobalt. Bergbau im Schwarzwald. Filderstadt: Markstein Verlag, 45-80.

Goš, V., Novák, J., Karel, J. 1985: Počátky osídlení Rýmařova. Památky archeologické LXXVI(1), 184-227.

Graulau, J. 2018: Mining Corporations of Western Europe: A Succinct Survey of Business Models of the Medieval World. Journal of the Mining Heritage Trust of Ireland 16, 3-20.
Graulau, J. 2019a: Capitalist miners in feudal Europe: A commentary on Marxist agrarian history. Journal of Agrarian Change 19, 596-613.

Graulau, J. 2019b: The Underground Wealth of Nations. On the Capitalist Origins of Silver Mining, A. D. 1150-1450. Yale: Yale University Press.

Grossmannová, D., Houzar, S., Hrazdil, V. 2014: Zdroje stř́bra v prostoru východní části Českomoravské vrchoviny ve 13. - 14. století. Acta rerum naturalium. Př́rodovědný časopis Vysočiny. Stříbrná Jihlava 2013 16, 109-119.

Günther, W. 2001: Von der Schlägel- und Eisenarbeit zur Sprengtechnik im Bergbau. Die bergmännischen Gewinnungs- und Fördermethoden. In: G. Ammerer, A. S. Weiß (eds.): Das Tauerngold im europäischen Vergleich. Archäologische und historische Beiträge des Internationalen Kongresses in Rauris vom 7. bis 9. Oktober 2000. Teil I. Salzburg: Gesellschaft für Salzburger Landeskunde, 131-139.

Haupt, P., Faßbinder, T., Mertl, P. 2013: LIDAR-Groundcheck. Zur Methodik minimalinvasiver Datierung montanarchäologischer Befunde aus LIDAR-Laserscans - LIDAR-Groundcheck. K metodice neinvazivního datování montánněarcheologických nálezů z laserového skenování LIDAR. In: R. Smolnik (ed.): ArcheoMontan 2012. Erkunden - Erfassen - Erforschen. Internationale Fachtagung Dippoldiswalde 18. bis 20. Oktober 2012. Průzkum - Evidence - Interpretace. Mezinárodní konference Dippoldiswalde, 18. až 20. ř́ijen 2012. Dresden: Landesamt für Archäologie, 31-38.

Hemker, Ch. 2011: Montanarchäologie und Denkmalpflege in Sachsen. In: R. Smolnik (ed.): Aufbruch unter Tage. Stand und Aufgaben der montanarchäologischen Forschung in Sachsen. Internationale Fachtagung Dippoldiswalde 9. bis 11. September 2010. Dresden: Landesamt für Archäologie, 37-48.

Hemker, Ch. 2013: Die hochmittelalterlichen Silberbergwerke von Dippoldiswalde im Kontext europäischer Montanarchäologieforschung. In: Y. Hoffmann, U. Richter (eds.): Die Frühgeschichte Freibergs im überregionalen Vergleich. Städtische Frühgeschichte. Bergbau - früher Hausbau. Halle (Saale): Mitteldeutscher Verlag GmbH, 225-241.

Heynowski, R. 2014: Airborne Laserscanning. Letecké laserové skenování. In: R. Smolnik (ed.): Silberrausch und Berggeschrey. Archäologie des mittelalterlichen Bergbaus in Sachsen und Böhmen. Stříbrná horečka a volání hor. Archeologie středověkého hornictví v Sasku a Čechách. Dresden: Verlag Beier \& Beran, 74-76.

Hilber, M. 2012: Der Bergbaurevier am Kogelmoos bei Schwaz. „Behausung, Hofstath und Gärtl zu ermelten Kogl“. Der montanistisch geprägte Arbeits-, Wohn- und Lebensraum am Kogelmoos in der Frühen Neuzeit. In: G. Goldenberg, U. Töchterle, K. Oeggl, A. Krenn-Leeb (eds.): HiMAT. Neues zur Bergbaugeschichte der Ostalpen. Archäologie Österreichs Spezial 4/2011. Wien: Österreichische Gesellschaft für Urund Frühgeschichte, 175-180.

Hoffmann, F. (ed.) 1959: Jihlavské právo. Havlíčkův Brod: Krajské nakladatelství.

Hoffmann, F. 1981: Neznámé znění velkého privilegia jihlavského (Ke vztahu listinných a rukopisných znění právních textů). Studie o rukopisech XX, 23-64.

Hoffmann, Y., Richter, U. 2012: Entstehung und Blïte der Stadt Freiberg. Die bauliche Entwicklung der Bergstadt vom 12. bis zum Ende des 17. Jahrhunderts. Halle (Saale): Mitteldeutscher Verlag GmbH.

Hofmann, J., Wolkersdorfer, Ch. 2013: Der historische Bergbau im Montafon. Schruns: Heimatschutzverein Montafon.

Holdermann, C.-S. 2011: Montanarchäologie am Südtiroler Schneeberg. Grundlagenforschungen zur mittelalterlichen und frühneuzeitlichen Bergbaugeschichte Südtirols. Wissenschaftliches Jahrbuch der Tiroler Landesmuseen 4, 58-71. 
Holdermann, C.-S. 2015a: Der Südtiroler Schneeberg/Moos in Passeier. Revierstrukturen aus 800 Jahren Bergbaugeschichte vor dem Hintergrund ausgewählter historischer und montanarchäologischer Quellen. In: 175 Jahre Montanuniversität Leoben. Von der montanistischen Lehranstalt in Vordernberg zur Universität in Leoben. Res montanarum. Sonderband 3/2015. Leoben: Montanuniversität Leoben, 17-40.

Holdermann, C.-S. 2015b: Geschichte und Technik des Montanwesens am Schneeberg/Moos in Passeier. Montanarchäologische Grundlagenforschungen zur mittelalterlichen und frühneuzeitlichen Bergbaugeschichte Südtirols. Ein Forschungsprojekt des Südtiroler BergbaumuseumsStandortbestimung und Perspektiven. In: 175 Jahre Montanuniversität Leoben. Von der montanistischen Lehranstalt in Vordernberg zur Universität in Leoben. Res montanarum. Sonderband 3/2015. Leoben: Montanuniversität Leoben, 89-106.

Holdermann, C.-S. 2015c: Montanarchäologie am Schneeberg, Moos in Passeier/Südtirol. Kulturraumanalysen im Erzrevier von Europas höchstgelegener Dauersiedlung. DVW Bayern e.V. Gesellschaft für Geodäsie, Geoinformation und Landmanagement, Mitteilungen 67(1), 65-84.

Hönig, H., Lentzsch, S. 2014: Das Bergwerk unter dem Busbahnhof. Beschreibung der untersuchten mittelalterlichen Grubenbaue unter dem Busbahnhof in Dippoldiswalde. Lkr. Sächsiche Schweiz-Osterzgebirge. Důl pod autobusovým nádražím. Popis prozkoumaného středověkého dolu pod autobusovým nádražím ve městě Dippoldiswalde, okr. Saské Švýcarsko - východní Krušnohoří. In: R. Smolnik (ed.): ArcheoMontan 2014. Ergebnisse und Perspektiven. Internationale Fachtagung Dippoldiswalde 23. bis 25. Oktober 2014. Výsledky a výhledy. Mezinárodní konference Dippoldiswalde 23. - 25. ř́jen 2014. Dresden: Landesamt für Archäologie Sachsen, 181-193.

Hosák, L. 1938: Historický místopis země Moravskoslezské. Praha: Společnost přátel starožitností československých v Praze.

Houzar, S. 1998a: Historické dolování v okolí Žd’áru nad Sázavou a Bystřice nad Pernštejnem. Západní Morava II, 18-33.

Houzar, S. 1998b: K historii dolování u Koroužného na západní Moravě. In: L. Macek, K. Malý (eds.): Stř́ibrná Jihlava. Seminár̆ K dějinám hornictví a důlních prací na Vysočině, Jihlava, 19. 9. - 20. 9. 1998. Sborník příspěvků. Jihlava, Havlíčkův Brod: Česká speleologická společnost ZO 6-18 Cunicunulus, o. s. Jihlavský netopýr, Muzeum Vysočiny v Jihlavě, Okresní vlastivědné muzeum Havlíčkův Brod, Státní okresní archiv Havlíčkův Brod, 72-79.

Houzar, S., Hrazdil, V., Malý, K., Pfeiferová, A., Sadílek, J. 2000: Charakteristika pozůstatků po starém dolování $\mathrm{Ag}-\mathrm{Pb}-\mathrm{Cu}$ rud ve štěpánovském rudním revíru na západní Moravě. Západní Morava IV, 116-137.

Houzar, S., Malý, K. 2002: Přehled mineralogie, ložiskových poměrů a historie štěpánovského rudního revíru na západní Moravě. Acta Musei Moraviae, Scientiae geologicae LXXXVII, 5-59.

Houzar, S., Sadílek, J., Gregor, F., Hrazdil, V., Pfeiferová, A. 2001: Př́spěvek k historii a topografii dolování při západním okraji svratecké klenby moravika (západní Morava). In: L. Macek, K. Malý, R. Schebesta (eds.): Stříbrná Jihlava 2001. Sborník př́spěvků ze seminář $\mathrm{K}$ dějinám hornictví a důlních prací na Vysočině, Jihlava, 15. 9. - 16. 9. 2001. Jihlava, Pelhřimov, Havlíčkův Brod: Česká speleologická společnost ZO 6-18 Cunicunulus, Muzeum Vysočiny Jihlava, Okresní muzeum Pelhřimov, Okresní vlastivědné muzeum Havlíčkův Brod, Státní okresní archiv Havlíčkův Brod, 20-29.

Hrazdil, V., Dočkal, P., Vokáč, M. 2007: Rudní lokality na Českomoravské vrchovině s nálezy hornických nástrojů. In: P. Hrubý (ed.): Stř́brná Jihlava 2007. Studie k dějinám hornictví a důlních prací.
Příspěvky z konference Stř́brná Jihlava 04.-07. 10. 2007 v Jihlavě. Věnováno Pavlu Rousovi k 60. narozeninám. Jihlava, Brno: Archaia Brno, Muzeum Vysočiny Jihlava, 282-305.

Hrazdil, V., Houzar, S. 2011: Ryzí stř́íbro z Borovce (štěpánovský rudní revír). Acta Musei Moraviae, Scientiae geologicae XCVI(1), 11-18.

Hrazdil, V., Houzar, S. 2013: Stříbro a zlato v galenitových rudách z žilných polymetalických ložisek Českomoravské vrchoviny. Acta Musei Moraviae, Scientiae geologicae XCVIII(2), 3-23.

Hruban, P., Kotris, J., Vranka, V., Večeřa, J. 2011: Zlatohorské podzemí. The Underground of Zlaté Hory. Olomouc: Václav Lukeš - Poznání.

Hrubý, P. 2011: Jihlava - Staré Hory. Archeologický výzkum středověkého důlního, úpravnického a obytného areálu v letech 2002-2006. Příspěvek ke studiu středověkého rudného hornictví. Praha, Brno: Univerzita Karlova v Praze, Filozofická fakulta.

Hrubý, P. 2014a: Od hertovního stříbra až téměř k minci, neboli, Od hutí až téměř k mincovnám. Archaeologia historica 39(2), 609-637.

Hrubý, P. 2014b: Martin Gojda, Jan John a kol.: Archeologie a letecké laserové skenování krajiny. Archaeology and airborne laser scanning of the landscape. Památky archeologické CV, 287-289.

Hrubý, P. 2016: Infrastruktur und Technologien der Silberproduktion des 13. Jahrhunderts im böhmisch-mährischen Mittelgebirge (Tschechien). Impressum. Mitteilungen der Deutschen Gesellschaft für Archäologie des Mittelalters und der Neuzeit 29, 183-200, tab. 6-7.

Hrubý, P. 2017: Nové průzkumy středověké montánní krajiny na Českomoravské vrchovině. Acta rerum naturalium. Př́rodovědný časopis Vysočiny. Stř́brná Jihlava 2016 21, 1-20.

Hrubý, P. 2019: Metalurgická produkční sféra na Českomoravské vrchovině v závěru přemyslovské epochy. Brno: Filozofická fakulta, Masarykova univerzita.

Hrubý, P., Derner, K., Skořepová, M. 2019a: Středověké hornické komunity v období Přemyslovců. Český časopis historický 117(4), 873-905.

Hrubý, P., Hejhal, P., Hoch, A., Kočár, P., Malý, K., Macháňová, L., Petr, L., Štelcl, J. 2012a: Středověký úpravnický a hornický areál Cvilínek u Černova na Pelhřimovsku. Památky archeologické CIII, 339-418.

Hrubý, P., Hejhal, P., Malý, K. 2007: Montanarchäologische Untersuchungen in Jihlava-Staré Hory (Iglau-Altenberg, Tschechien). Zeitschrift für Archäologie des Mittelalters 35, 17-60.

Hrubý, P., Hejhal, P., Malý, K. 2010: Cvilínek: a new high medieval Mining Site in the Ore District Pelhřimov on the Bohemian-Moravian Uplands. In: J. Silvertant (ed.): Mining archaeological Research. Interdisciplinary Methodology. $5^{\text {th }}$ International Symposium on archaeological Mining History. Valkenburg aan de Geul, Freiberg: Institute Europa Subterranea Valkenburg aan de Geul, 74-99.

Hrubý, P., Hejhal, P., Malý, K. 2012b: Dva zaniklé středověké důlní a zpracovatelské provozy na Českomoravské vrchovině. Acta rerum naturalium. Př́rodovědný časopis Vysočiny. Stříbrná Jihlava 2010 12, 145-180.

Hrubý, P., Hejhal, P., Malý, K., Kočár, P., Petr, L. 2014: Centrální Českomoravská vrchovina na prahu vrcholného střredověku. Archeologie, geochemie a rozbory sedimentárních výplní niv. Brno: Masarykova univerzita.

Hrubý, P., Koštál, M., Malý, K., Těsnohlídek, J. 2019b: Středověká úpravna rud u Koječína na Českomoravské vrchovině: k poznání technologií produkce stříbra ve státě posledních Přemyslovců. Archaeologia historica 44(2), 949-981.

Hrubý, P., Malý, K., Lajtkepová, P. 2015: Zmizelý svět středověkého hornictví na Českomoravské vrchovině. Katalog k výstavě realizované 11. zář́ - 10. listopadu 2015 v Muzeu Vysočiny Jihlava. Jihlava: Muzeum Vysočiny Jihlava.

Jan, L. 2013: Důlní podnikání. In: L. Jan (ed.): Dějiny Brna. 2. Středověké město. Brno: statutární město Brno, Archiv města Brna, 486-488. 
Ježek, B., Hummel, J. (transl. et eds.) 1933: Jiř́ího Agricoly Dvanáct knih o hornictví a hutnictví. Georgii Agricolae De re metallica libri XII, Basileae MDLVI. Praha: Matice hornicko-hutnická.

John, J., Gojda, M. 2013: Ex caelo lux. Principy leteckého laserového skenování a jeho využití pro dálkový archeologický průzkum. In: M. Gojda, J. John a kolektiv: Archeologie a letecké laserové skenování krajiny. Plzeň: Katedra archeologie, Západočeská univerzita v Plzni, 8-20.

Jurman, H. 1985: Štěpánov nad Svratkou 1285-1985. Štěpánov nad Svratkou: MNV Štěpánov nad Svratkou.

Jurman, H. 2014: V nejkrásnějším údolí na světě. Štěpánov nad Svratkou: Městys Štěpánov nad Svratkou.

Kenzler, H. 2009: Struktur und Entwicklung der Bergstadt auf dem Treppenhauer. Ergebnisse der archäologischen Untersuchungen von 2005 bis 2007. Arbeits- und Forschungsberichte zur sächsischen Bodendenkmalpflege 50, 2008, 263-306.

Kenzler, H. 2012: Die hoch- und spätmittelalterliche Besiedlung des Erzgebirges. Strategien zur Kolonisation eines landwirtschaftlichen Ungunstraumes. Bonn: Dr. Rudolf Habelt GmbH.

Kenzler, H. 2014: Bergbau und Kolonisation. Die Rolle des Montanwesens innerhalb der mittelalterlichen Besiedlungsgeschichte des Erzgebirges. Hornictví a kolonizace. Role hornictví ve středověkém osídlení Krušných hor. In: R. Smolnik (ed.): ArcheoMontan 2013. Krušná krajina Erz(gebirgs) landschaft - Ore Landscape. Mezinárodní konference. Kadan̆, 26. až 28. zář́ 2013. Internationale Fachtagung. Kadan̆ 26. bis 28. September 2013. Dresden: Landesamt für Archäologie Sachsen, 157-167.

Klápště, J. 2016: The Archaeology of Prague and the Medieval Czech Lands, 1100-1600. Sheffield, Bristol: Equinox Publishing Ltd.

Kořan, J. 1950: Dějiny dolování v rudním okrsku kutnohorském. Praha: Vědecko-technické nakladatelství.

Kořan, J. 1955: Přrehledné dějiny československého hornictví. I. Praha: Nakladatelství Československé akademie věd.

Kořan, J. 1974: Rozmach feudální techniky. Technika v období vrcholného feudalismu (13. - 16. st.). Nerostné suroviny. In: L. Nový a kolektiv: Dějiny techniky v Československu do konce 18. století. Praha: Academia, 210-252.

Kořan, J. 1988: Sláva a pád starého českého rudního hornictví. Př́ibram: komitét sympozia Hornická Př́íbram ve vědě a technice.

Krause, R. 2013: Mittelalterlicher Bergbau auf dem Kristberg im Montafon. Montanarchäologische Untersuchungen in einem kleinen Montanrevier in den Zentralalpen. In: R. Krause (ed.): Mittelalterlicher Bergbau auf dem Kristberg im Montafon, Vorarlberg (Österreich). Bonn: Dr. Rudolf Habelt GmbH, 1-30.

Krause, R., Würfel, F., Röpke, A., Klopfer, R., Friederich, J., Zerl, T. 2015: Ein mittelalterliches Montanrevier im Montafon in den Zentralalpen, Vorarlberg. In: T. Stöllner, K. Oeggl (eds.): Bergauf Bergab. 10.000 Jahre Bergbau in den Ostalpen. Wissenschaftlicher Beiband zur Ausstellung im Deutschen Bergbau-Museum Bochum vom 31. 10. 2015 - 24. 4. 2016. Im Vorarlberg Museum Bregenz vom 11. 6. 2016 - 26. 10. 2016. Bochum: VML Verlag Marie Leidorf $\mathrm{GmbH}, 463-473$.

Křístek, Z. 2010: Katalog starých důlních děl ve Štěpánově. Diamo XV (XXXII)/3, březen 2010, 2-3.

Kuča, K. 2008: Města a městečka v Čechách, na Moravě a ve Slezsku. VII. díl. Str-U. Praha: Libri.

Kudrnáč, J. 1987: Archeologické výzkumy hornických stařin v povodí Litavky a středověkých zlatodolů u Čeliny. Vlastivědný sborník Podbrdska 38-39, 221-247.

Kvietok, M. 2014: Stav a perspektívy montánnej archeológie na hornom Pohroní. Acta rerum naturalium. Př́rodovědný časopis Vysočiny. Stř́íbrná Jihlava 2013 16, 1-17.
Legut-Pintal, M., Łuczak, A., Piekalski, J. 2017: Lidar images in identification of small scale placer gold mines. Case study of Microregion Wleń/Lähn in the Sudetes Foothills, Silesia, Poland. Acta rerum naturalium. Př́rodovědný časopis Vysočiny. Stříbrná Jihlava 2016 21, 169-176.

Leminger, O. 1929: Dějiny horního práva na území republiky Československé. In: E. Hácha, A. Hobza, J. Hoetzel, F. Weyr, K. Laštovka (eds.): Slovník veřejného práva československého. Svazek I. A až Ch. Brno: Polygrafia, Rudolf M. Rohrer, 749-755.

Lissek, P., Holešinský, O. 2014: Letecké laserové skenování referenční oblasti projektu ArcheoMontan. Airborne Laserscanning des Referenzgebietes des Projektes ArcheoMontan. In: R. Smolnik (ed.): ArcheoMontan 2013. Krušná krajinaErz(gebirgs)landschaft - Ore Landscape. Mezinárodní konference. Kadan̆, 26. až 28. záři 2013. Internationale Fachtagung. Kadan̆ 26. bis 28. September 2013. Dresden: Landesamt für Archäologie Sachsen, 7-18.

Lobbedey, U., Vierck, S., Dahm, C., Weisgerber, G. 1998: Zeitstellung, Struktur und Bedeutung der Bergbausiedlung Altenberg. Ofenanlagen. Die obertätigen Befunde. In: C. Dahm, U. Lobbedey, G. Weisgerber: Der Altenberg. Bergwerk und Siedlung aus dem 13. Jahrhundert im Siegerland. Band 1: Die Befunde. Bonn: Dr. Rudolf Habelt GmbH, 21-132, plány 1-5.

Maciejak, K., Kowalski, A., Maciejak, M. 2017: Kopalnie złota na Wielisławce (Pogórze Kaczawskie). Hereditas Minariorum 4, 45-63.

Mair, V., Vavtar, F., Schölzhorn, H., Schölzhorn, D. 2007: Der Zink-Blei-Erzbergbau am Schneeberg, Südtirol. Mitteilungen der Österreichischen Mineralogischen Gesellschaft 153, 145-180.

Malý, K. 2020: Mineralogické a chemické složení rud, strusek a slitků z lokality Havírna u Štěpánova nad Svratkou. Acta rerum naturalium. Přírodovědný časopis Vysočiny. Stříbrná Jihlava 2019 24, v tisku.

Malý, K., Dolníček, Z. 2005: Pb-Zn-Ag vein mineralization of the central part of the Českomoravská vrchovina Upland (Czech Republic): S, C, and O stable isotope study. Bulletin of Geosciences 80(4), 307-319.

Meyerdirks, U. 2007: Medieval and early modern mining in the Northern Black Forest (SW-Germany): An integrated historicoarchaeological approach and its synergetic effects. In: Medieval Europe Paris 2007. 4th International Congress of Medieval and Modern Archaeology. Paris: Institut National d'Histoire de l'Art, Université Paris, 1-8. Dostupné také z: http://medievaleurope-paris-2007.univ-paris1.fr/U.Meyerdirks.pdf.

Militký, J. 2006: „Bronzové“ brakteáty a tzv. brakteátová pouzdra ve střední Evropě. In: P. Hrubý, Z. Jaroš, P. Kočár, K. Malý, J. Mihályiová, J. Militký, D. Zimola: Středověká hornická aglomerace na Starých Horách u Jihlavy. Památky archeologické XCVII, 244-251.

Militký, J. 2007: Př́íspěvek k poznání a interpretaci bronzových brakteátů na základě jejich nálezů ve střední Evropě. In: D. Grossmannová, T. Krejčík, J. T. Štefan (eds.): Sborník konference věnované prof. Jiř́mu Sejbalovi 1929-2004. Postavení Moravy $v$ mincovnictví a peněžních vatazích ve střední Evropě. Ostrava: Jan Štefan MARQ, 55-68.

MON-CA-B: Fond: Baartholomäberg, Pfarrarchiv [online]. In: Monasterium.net. [cit. 2020-08-18]. Dostupné z: https:// www.monasterium.net/mom/AT-VLA/BartholomaebergPfA/fond.

MON-CA-S: Fond: Silbertal, Pfarrarchiv [online]. In: Monasterium.net. [cit. 2020-08-18]. Dostupné z: https:/www.monasterium.net/ mom/AT-VLA/SilbertalPfA/fond

Morávek, P., Litochleb, J. 2002: Jílovské zlaté doly. Jílové u Prahy: Regionální muzeum v Jílovém u Prahy.

MZA, F 78: Moravský zemský archiv v Brně, fond F 78 (č. 344) Velkostatek Pernštejn 1525-1946. 
Neuhauser, G. 2013: Religion und Bergbau im Montafon. Der Bartholomäberger Knappenaltar, St. Agatha und die Dreifaltigkeitsbruderschaft am Kristberg. In: R. Krause (ed.): Mittelalterlicher Bergbau auf dem Kristberg im Montafon, Vorarlberg (Österreich). Bonn: Dr. Rudolf Habelt GmbH, 31-43.

Nováček, K. 1993: Klasifikace povrchových stop po zaniklé těžbě surovin (př́spěvek $\mathrm{k}$ metodice povrchového průzkumu). Studie $z$ dějin hornictví 23, 7-11. Upravená a doplněná verze dostupná z: https://www.kar.zcu.cz/texty/Novacek1993.htm.

Nováček, K. 1994: Hornická sídliště. Příspěvek ke studiu středověkého neagrárního osídlení. In: Mediaevalia archaeologica Bohemica 1993. Památky archeologické. Supplementum 2. Praha: Institute of Archaeology, Prague, 158-170.

Nováček, K. 2001: Nerostné suroviny středověkých Čech jako archeologický problém: bilance a perspektivy výzkumu se zaměřením na výrobu a zpracování kovů. Archeologické rozhledy LIII, 279-309.

Novotný, P., Zimák, J. 2003: Zlaté Hory. Historie a současnost ložiska zlata evropského významu - Zlaté Hory (Zuckmantel). Geschichte und Gegenwart der Goldlagerstätte von Gesamteuropäischer Bedeutung. Olomouc, Zlaté Hory: Memoria Olomouc.

Ottenthal, E. von, Redlich, O. 1896: Archiv-Berichte aus Tirol. II. Band. Wien, Leipzig: Commissions-Verlag von Wilhelm Braumüller.

Pacina, J., Brůna, V. 2014: Sběr prostorových dat s využitím bezkontaktních metod. Erfassung von Geodaten mithilfe von nichtinvasiven Messmethoden. In: R. Smolnik (ed.): ArcheoMontan 2014. Ergebnisse und Perspektiven. Internationale Fachtagung Dippoldiswalde 23. bis 25. Oktober 2014. Výsledky a výhledy. Mezinárodní konference Dippoldiswalde 23. - 25. ř́jen 2014. Dresden: Landesamt für Archäologie Sachsen, 69-80.

Paulinyi, O. 1966: Die anfänglichen Formen des Unternehmens im Edelerzbergbau zur Zeit des Feudalismus. Acta Historica Academiae Scientiarum Hungaricae 12, 25-57, 261-318.

Petrlík, J., Štarha, I. 1979: Okres Žd’ár nad Sázavou. In: J. Dř́ímal, I. Štarha (eds.): Znaky a pečeti jihomoravských měst a městeček. Brno: Blok, 378-407, 442, 449-450, 481-483, 512-513, tab. XXI-XXIII, L-LI.

Pierre, F. 2011: Étude de l'évolution des procédés de percement de la roche en mine. In: R. Smolnik (ed.): Aufbruch unter Tage. Stand und Aufgaben der montanarchäologischen Forschung in Sachsen. Internationale Fachtagung Dippoldiswalde 9. bis 11. September 2010. Dresden: Landesamt für Archäologie, 223-231.

Pichler, A. 2003: Bergbau in Ostkärnten. Eine Bestandsaufnahme der noch sichtbaren Merkmale der historischen Bergbaue in Ostkärnten. Klagenfurt: Naturwissenschaftlicher Verein für Kärnten.

Podlaha, A. 1908: Soupis památek historických a uměleckých v království Českém od pravěku do počátku XIX. století. XXVIII. Politický okres Vinohradský. Praha: Archaeologická komise při České akademii císaře Františka Josefa pro vědy, slovesnost a umění.

Polák, A. 1960: Nerostné bohatství Bystřicka. Brno: Krajské nakladatelství v Brně.

Pratt, P. L. 2010: The arrow. In: R. Hardy: Longbow. A Social and Military History. Yeovil: Haynes Publishing, 226-232.

Rauschkolb, M. 1999: Kirche und Friedhof der Bergbausiedlung Sulzburg. Archäologische Nachrichten aus Baden 61/62, 101-107.

RBM II: Regesta diplomatica nec non epistolaria Bohemiae et Moraviae. Pars II. Annorum 1253-1310. Ed. J. Emler. Pragae 1882: Sumptibus regiae scientiarum societatis Bohemiae.

RBM III: Regesta diplomatica nec non epistolaria Bohemiae et Moraviae. Pars III. Annorum 1311-1333. Ed. J. Emler. Pragae 1890: Sumptibus regiae scientiarum societatis Bohemiae.

Rees, G. 1995: The Physics of Medieval Archery. Physics Review 4(3), January.
Richter, U. 1994: Der Freiberger Raum. In: K. Eckstein, A. Hauptmann, T. Rehren, U. Richter, W. Schwabenicky: Hochmittelalterliches Montanwesen im sächsischen Erzgebirge und seinem Vorland. Der Anschnitt 46(4-5), Sonderdruck, 118-121.

Richter, U. 2013: Der Hausbau in Freiberg im 12. und 13. Jahrhundert. In: Y. Hoffmann, U. Richter (eds.): Die Frühgeschichte Freibergs im überregionalen Vergleich. Städtische Frühgeschichte. Bergbau - früher Hausbau. Halle (Saale): Mitteldeutscher Verlag GmbH, 369-388.

Rous, P. 1996: Středověké sídliště na k. ú. Termesivy, o. Havlíčkův Brod. Zpravodaj muzea v Hradci Králové 22, 78-85.

Rous, P. 1998: Středověké hornické sídliště neznámého jména u Havlíčkova Brodu na k. ú. Termesivy. In: L. Macek, K. Malý (eds.): Stř́ibrná Jihlava. Seminár̆ K dějinám hornictví a důlních prací na Vysočině, Jihlava, 19. 9. - 20. 9. 1998. Sborník příspěvkü. Jihlava, Havlíčkův Brod: Česká speleologická společnost ZO 6-18 Cunicunulus, o. s. Jihlavský netopýr, Muzeum Vysočiny v Jihlavě, Okresní vlastivědné muzeum Havlíčkův Brod, Státní okresní archiv Havlíčkův Brod, 102-115.

Rous, P. 2001: K závěrečné fázi vrcholně středověkého hornictví na Havlíčkobrodsku. In: L. Macek, K. Malý, R. Schebesta (eds.): Stř́brná Jihlava 2001. Sborník př́spěvků ze semináře K dějinám hornictví a důlních prací na Vysočinĕ, Jihlava, 15. 9. - 16. 9. 2001. Jihlava, Pelhřimov, Havlíčkův Brod: Česká speleologická společnost ZO 6-18 Cunicunulus, Muzeum Vysočiny Jihlava, Okresní muzeum Pelhřimov, Okresní vlastivědné muzeum Havlíčkův Brod, Státní okresní archiv Havlíčkův Brod, 66-81.

Rous, P. 2004: Stř́ibrnorudné hornictví na Havlíčkobrodsku od 13. do 17. století. Archeologia technica 15, 49-58.

Rous, P., Havlíček, J., Malý, K. 2004: Nález mlecích kamenů z rudního mlýna na katastru Stříbrné Hory na Havlíčkobrodsku. In: L. Macek, J. Hošková, D. Zimola (eds.): Stříbrná Jihlava 2004. Seminár̆ K dějinám hornictví a důlních prací na Vysočině, Jihlava, 17. 9. - 19. 9. 2004. Sborník príspěvků. Jihlava, Havlíčkův Brod, Pelhřimov, Třebíč, Kámen, Brno: Muzeum Vysočiny Jihlava, Muzeum Vysočiny Havlíčkův Brod, Muzeum Vysočiny Pelhřimov, Muzeum Vysočiny Třebíč, Hrad Kámen, MZA Brno - SOkA Havlíčkův Brod, MZA Brno - SOkA Jihlava, MZA Brno - SOkA Pelhřimov, Archaia Brno, o. p. s., ZO 6-18 ČSS Cunicunulus, Jihlavský netopýr, o. s., 128-134.

Řezníček, J. 2002: Moravské a slezské urbáře po 1372/před 1407-1771(1849). Katalog. Praha: Odbor archivní správy Ministerstva vnitra ČR.

Sadílek, J. 1996: Pozůstatky tvrze v Prosetíně. Hláska. Zpravodaj Klubu Augusta Sedláčka VII(4), 41-43.

Sadílek, J. 2008: Založení kláštera sv. Kříže, jeho trvání a zánik. In: L. Jan (ed.): Doubravník v dějinách 1208-2008. Doubravník: Městys Doubravník, 63-89.

Sadílek, J. 2012: Tř̌i př́íspěvky k poznání historické architektury na Bystřicku. Vlastivědný sborník Bystřicka I, 25-46.

Sadílek, J. 2014: Prosetín. Historický vývoj stavebních památek a osídlení obce. Rukopis. Bystřice nad Pernštejnem.

Sedláček, P. 1992: Páni z Medlova. Jižní Morava 28, sv. 31, 37-55.

Sedláček, P. 2000: Páni na Pernštejně do husitských válek. Zprávy Státního památkového ústavu v Brně 4, 8-20.

Schadelbauer, K. 1930a: Der Weihebrief für die St. Barbara-Kapelle. Der Schlern 11(7), 288-289.

Schadelbauer, K. 1930b: Vom „Sitz des Gozzo“ zum blühenden Knappendorf. Der Schlern 11(7), 266-271.

Scheibenstock, E. 2004: St. Agatha Bergknappenkirche. Das Bruderhäuslein und die Klause von Jos Erhart. Kristberg: Panoramagasthof Kristberg.

Scholz, V. 2011: Die Grubenbaue des hochmittelalterlichen Bergbaus von Dippoldiswalde vom ausgehenden 12. bis zur Mitte des 13. Jahrhunderts. In: R. Smolnik (ed.): Aufbruch unter Tage. Stand 
und Aufgaben der montanarchäologischen Forschung in Sachsen. Internationale Fachtagung Dippoldiswalde 9. bis 11. September 2010. Dresden: Landesamt für Archäologie, 111-116.

Scholz, V. 2013: Versuch einer beschreibenden Rekonstruktion der Bergbautechniken und Abbautechnologien im hochmittelalterlichen Bergbau von Dippoldiswalde. Pokus o popisnou rekonstrukci hornických technologií a technologií těžby ve vrcholně středověkém dolu v Dippoldiswalde. In: R. Smolnik (ed.): ArcheoMontan 2012. Erkunden - Erfassen - Erforschen. Internationale Fachtagung Dippoldiswalde 18. bis 20. Oktober 2012. Průzum - Evidence - Interpretace. Mezinárodní konference Dippoldiswalde, 18. až 20. řijen 2012. Dresden: Landesamt für Archäologie, 237-248.

Schreiber, G. 1962: Der Bergbau in Geschichte, Ethos und Sakralkultur. Wiesbaden: Springer Fachmedien Wiesbaden GmbH.

Schröder, F. 2015: Die montanarchäologischen Ausgrabungen in Niederpöbel (2011-2013). Befunde und Ergebnisse. In: R. Smolnik (ed.): ArcheoMontan 2015. Montanarchäologie im Osterzgebirge. Montánní archeologie ve východním Krušnohoří. Dresden: Landesamt für Archäologie Sachsen, 23-165.

Schröder, F. 2018: Funde aus den mittelalterlichen Bergwerken von Niederpöbel. Dresden: Landesamt für Archäologie Sachsen.

Schwabenicky, W. 2009: Der mittelalterliche Silberbergbau im Erzgebirgsvorland und im westlichen Erzgebirge. Chemnitz: Verlag Klaus Gumnior.

Schwabenicky, W. 2011: Mittelalterlicher Silberbergbau in Sachsen: Forschungsstand - Probleme - Fragestellungen. In: R. Smolnik (ed.): Aufbruch unter Tage. Stand und Aufgaben der montanarchäologischen Forschung in Sachsen. Internationale Fachtagung Dippoldiswalde 9. bis 11. September 2010. Dresden: Landesamt für Archäologie, 7-36.

Schwabenicky, W. 2014: Die Bergstadt Bleiberg auf dem Treppenhauer. Hornické město Bleiberg na Treppenhaueru. In: R. Smolnik (ed.): Silberrausch und Berggeschrey. Archäologie des mittelalterlichen Bergbaus in Sachsen und Böhmen. Stříbrná horečka a volání hor. Archeologie středověkého hornictví v Sasku a Čechách. Dresden: Verlag Beier \& Beran, 163-170.

Sikora, M. 2010: Mapy historických důlních děl ve štěpánovském rudním revíru. Ostrava: Diamo s. p., odštěpný závod Odra.

Somer, T. 2012: Smil z Lichtenburka. Př́běh velmože bouřlivého věku. České Budějovice: Bohumír Němec - Veduta.

Somer, T., Šrámek, J. 2015: Benediktinské opatství ve Vilémově. Dějiny zapomenutého kláštera na česko-moravském pomezí. České Budějovice: Bohumír Němec - Veduta.

Spiong, S. 1999: Die Bergleutesiedlung auf dem „Geißmättle in Sulzburg“. Archäologische Nachrichten aus Baden 61/62, 65-84.

Srbik, R. R. v. 1929: Überblick des Bergbaues von Tirol und Vorarlberg in Vergangenheit und Gegenwart. Berichte des Naturwissenschaftlich-medizinischen Vereines zu Innsbruck 41, 113-279.

Starková, L. 2010: LIDAR. Potenciál a využití laserového skeneru na př́ikladové studii Národního parku České Švýcarsko. In: M. Gojda a kolektiv: Studie k dálkovému průzkumu v archeologii. Plzeň: Katedra archeologie Fakulty filozofické, Západočeská univerzita Plzeň, 104-111.

Sternberg, K., Sterly, A. 1837: Umrisse einer Geschichte der böhmischen Bergwerke. Erster Band. Zweite Abtheilung. Prag: Gottlieb Haase Söhne.

Steuer, H. (ed.) 1999: Alter Bergbau im Sulzbachtal, Südschwarzwald. Archäologische Nachrichten aus Baden 61/62, 1-144.

Steuer, H., Goldenberg, G. 2002: Bergbausiedlungen des Mittelalters im südlichen Schwarzwald. In: P. Ettel, R. Friedrich, W. Schier (eds.): Interdisciplinäre Beiträge zur Siedlungsarchäologie. Gedenkschrift für Walter Janssen. Internationale Archäologie. Rahden/Westf.: Verlag Marie Leidorf GmbH, 403-423.
Stránská, R. 2015: Těžební areál Havírna. In: M. Tomášek (ed.) a kolektiv: 100 zajímavých archeologických lokalit Moravy a Slezska. Praha: Národní památkový ústav, 363-366.

Stránský, K., Janová, D., Karbowniczek, D., Stránský, L. 2013a: $\mathrm{K}$ těžbě a zpracování stř́íbronosných rud na pernštejnském panství. In: K. Stránský, D. Janová, L. Stránský a kolektiv: Těžba a hutnické zpracování polymetalických rud na Českomoravské vrchovině. Brno: Česká slévárenská společnost, člen ČSVTS Praha, 42-47.

Stránský, K., Janová, D., Stránský, L., Roupcová, P. 2013b: Těžba a zpracování stř́ibronosných rud ve Švařci u Štěpánova nad Svratkou. I. II. In: K. Stránský, D. Janová, L. Stránský a kolektiv: Těžba a hutnické zpracování polymetalických rud na Českomoravské vrchovině. Brno: Česká slévárenská společnost, člen ČSVTS Praha, 35-41.

Strassburger, M. 2012: Middle-aged silver, coper and lead mining near Ramsbeck. Acta rerum naturalium. Př́rodovědný časopis Vysočiny. Stř́brná Jihlava 2010 12, 31-44.

Stromer, W. von 1984: Wassersnot und Wasserkünste im Bergbau des Mittelalters und der frühen Neuzeit. In: W. Kroker, E. Westermann (eds.): Montanwirtschaft Mitteleuropas vom 12. bis 17. Jahrhundert. Stand, Wege und Aufgaben der Forschung. Der Anschnitt, Beiheft Nr. 2, 1984. Bochum: Deutsches Bergbau-Museum, 50-73.

Šmerdová, D., Beránek, K. (eds.) 1985: Archiv České koruny. Edice faksimiliú. Archivum Coronae regni Bohemiae. Editio dilomatum phototypica. III. 1347-1355. Praha: Národní archiv.

Šmilauerová, E., Břicháček, P. 1987: Poznámky ke stavebnímu, sociálnímu a správnímu vývoji Jílového v předhusitské době. In: Jílové u Prahy. Historie a současnost. Jílové u Prahy: Okresní muzeum Praha-západ, 41-50.

Štancl, R. 1980a: Geologicko-ložisková charakteristika některých rudních výskytů ve svratecké klenbě. Rkp. diplomové práce. Brno: Univerzita Jana Evangelisty Purkyně. Přírodovědecká fakulta. Katedra geologie a paleontologie. Uloženo: Ústřední knihovna Př́ŕrodovědecké fakulty Masarykovy univerzity.

Štancl, R. 1980b: Geologicko-ložisková a geochemická charakteristika některých rudních výskytů ve svratecké klenbě. Rkp. rigorózní práce. Brno: Univerzita Jana Evangelisty Purkyně. Př́rodovědecká fakulta. Katedra geologie a paleontologie. Uloženo: Ústřední knihovna Přírodovědecké fakulty Masarykovy univerzity.

Štarha, I. 1980: Od nejstarších zpráv do husitských válek. In: I. Štarha, M. Zemek (eds.) a kol.: Bystřice nad Pernštejnem. Od minulosti k současné revoluční přeměně města. Brno: Blok, 17-28, 255, obr. 1.

Štarha, I. 1985: „Povýšení“ Štěpánova nad Svratkou na městečko. (K 700. výročí nejstarší písemné zprávy). Vlastivědný věstník moravský XXXVII(1), 78-80.

Štarha, I. 2004: Dvě rozdílná století doubravnického kláštera. Sborník prací Filozofické fakulty brněnské univerzity C 50 (2003), 31-52.

Tadra, F. (ed.) 1882: Summa Gerhardi. Ein Formelbuch aus der Zeit des Königs Johann von Böhmen (c. 1336-45). Archiv für österreichische Geschichte LXIII, 305-594.

Tejkal, M. 2017-2019: Havírna Štěpánov - digitální model terénu 2017-2019. Technické zprávy. Rukopis. Dolní Kounice.

Tenora, J. 1907: Vlastivěda moravská. II. Místopis. Bystřický (n. P.) okres. Brno: Musejní spolek v Brně.

Teplý, J. 1996: Pernštejnové ve 13. - 14. století. Pardubice: Východočeské muzeum Pardubice, Historický klub - pobočka Pardubice.

Teplý, J. 2016: Rod Pernštejnů za přemyslovských a lucemburských králů. Pardubice: Univerzita Pardubice.

Tomaschek, Edl. v. Stradowa J. A. (ed.) 1897: Das alte Bergrecht von Iglau und seine bergrechtlichen Schöffensprüche. Innsbruck: Verlag der Wagner'schen Universitäts-Buchhandlung. 
Torggler, A. 2019a: Der mittelalterliche Begbau mit besonderer Berücksichtigung des Schneebergs in Passeier. Zur Organisationsform des hochmittelalterlichen Bergbaus im Tiroler Raum. In: Ch. Terzer, A. Toggler (eds.): Bergwerk Schneeberg I. Archäologie - Geschichte - Technik bis 1870. Brixen/Bressanone: Verlag A. Weger, 14-35.

Torggler, A. 2019b: Die Verwaltung des Südtiroler Schneebergs bis 1869/71. In: Ch. Terzer, A. Toggler (eds.): Bergwerk Schneeberg I. Archäologie - Geschichte - Technik bis 1870. Brixen/Bressanone: Verlag A. Weger, 158-164.

Ungerank, D., Tropper, P. 2014: Montanhistorischer Streifzug über das Bergbaurevier Pflerschtal. Geo.Alp 11, 103-114.

Valentová, J. 1999: Hornická osada Antiqua Cuthna. Realita pohledem archeologického výzkumu. Kutnohorsko. Vlastivědný sborník 1/99, 16-19.

Vaněk, V. 2011: Oltár̆ní fundace kutnohorských měštanů v předhusitské době [online]. Rkp. disertační práce. Praha: Univerzita Karlova. Filozofická fakulta. Katedra pomocných věd historických a archivního studia. Uloženo: Digitální repozitáŕ Univerzity Karlovy. [cit. 2020-10-30]. Dostupné z: https://dspace.cuni.cz/ handle/20.500.11956/47043.

Vaněk, V. 2015: Otazníky nad vývojem farní správy v předhusitské Kutné Hoře. In: J. Hrdina, K. Jíšová (eds.): Městský farní kostel $v$ českých zemích ve středověku. Documenta Pragensia Supplementa VI. Praha: Archiv hlavního města Prahy, Scriptorium, 79-98, 340-341.

Večeřa, J. 1996: Předběžné výsledky kategorizace pozůstatků dolování ve Zlatých Horách. Archeologia technica 10, 98-102.

Večeřa, J. 1998: Typologie povrchových tvarů vzniklých těžbou rud a jejich časové zařazení. Studie z dějin hornictví $27,81-89,93$.

Večeřa, J. 2004: Povrchové pozůstatky po těžbě rud a jejich vyhodnocení. In: K. Nováček (ed.): Těžba a zpracování drahých kovũ: sídelní a technologické aspekty. Mediaevalia archaeologica 6. Praha, Brno, Plzeň: Archeologický ústav AV ČR Praha, Archeologický ústav AV ČR Brno, Západočeská univerzita v Plzni, 145-156.

Večeřa, J. 2007: Analýza povrchových tvarů Andělskohorského rudního revíru, část Hláska-Vysoká. In: P. Hrubý (ed.): Stř́ibrná Jihlava 2007. Studie $k$ dějinám hornictví a důlních prací. Příspěvky z konference Stříbrná Jihlava 04.-07. 10. 2007 v Jihlavě. Věnováno Pavlu Rousovi k 60. narozeninám. Jihlava, Brno: Archaia Brno, Muzeum Vysočiny Jihlava, 64-75.

Večeřa, J. 2009a: Důlní míry v Jeseníkách a možnosti jejich interpretace. In: J. Labuda (ed.): Argenti fodina 2008. Zborník prednášok z medzinárodnej konferencie Argenti fodina 2008, konanej v dňoch 3. - 5. septembra $2008 v$ Banskej Štiavnici. Banská Štiavnica: Slovenské banské múzeum Banská Štiavnica, 60-68.

Večeřa, J. 2009b: Průzkumná pole - klíč k rozluštění středověkých a novověkých děl? Studie z dějin hornictví 38, 5-16.

Večeřa, J. 2013: Průzkumná pole - klíč k rozluštění středověkých a novověkých děl? Grubenfelder - Ein Schlüssel zur Differenzierung von Alt- und Neubergbau? In: R. Smolnik (ed.): ArcheoMontan 2012. Erkunden - Erfassen - Erforschen. Internationale Fachtagung Dippoldiswalde 18. bis 20. Oktober 2012. Průzkum - Evidence - Interpretace. Mezinárodní konference Dippoldiswalde, 18. $a \check{z} 20 . \breve{r}$ íjen 2012. Dresden: Landesamt für Archäologie, 45-58.

Večeřa, J. 2017: Jednotná terminologie - základ úspěšné mezioborové spolupráce. Acta rerum naturalium. Př́rodovědný časopis Vysočiny. Stř́brná Jihlava 2016 21, 41-46.

Večeřa, J., Večeřová, V. 1999: Etapovitost těžby na lokalitě Ludvíkov. Studie z dějin hornictví 28, 15-23.
Večeřa, J., Večeřová, V. 2007: Hornická osada ve Zlatohorském rudním revíru - „Erlitz“ nebo Altenberg? Archeologia technica 18, 60-63.

Večeřa, J., Večeřová, V. 2010: Historie zlatohorských dolů. Jeseník: RNDr. Viera Večeřová - PINKA.

Večeřová, V., Večeřa, J. 2013: Obraz počátků dolování. Das Bild der Anfänge des Bergbaus. In: T. Karel, A. Kratochvílová (eds.): Proměny montánní krajiny. Historické sídelní a montánní struktury Krušnohoří. Wandel der Bergbau-Kulturlandschaft Erzgebirge. Loket: Národní památkový ústav, územní odborné pracoviště v Lokti, 142-151, 207.

Velebil, D., Kráčmar, L. 2002: Ložisko Borovec u Štěpánova (štěpánovský revír). Minerál X(3), 163-181.

Velímský, F. 2007: Nově evidované středověké montánní aktivity na Kutnohorsku. In: P. Hrubý (ed.): Stř́ibrná Jihlava 2007. Studie $k$ dějinám hornictví a důlních prací. Příspěvky z konference Stř́brná Jihlava 04.-07. 10. 2007 v Jihlavě. Věnováno Pavlu Rousovi $k$ 60. narozeninám. Jihlava, Brno: Archaia Brno, Muzeum Vysočiny Jihlava, 90-101.

Velímský, F. 2012: Zaniklý těžební areál U Všech Svatých na Horách Kutných. Acta rerum naturalium. Př́rodovědný časopis Vysočiny. Strúibrná Jihlava 2010 12, 203-210.

Velímský, F. 2017: Montánně archeologický výzkum středověkých horních děl v Kutné Hoře v letech 1999-2016. Acta rerum naturalium. Př́rodovědný časopis. Vysočiny Stříbrná Jihlava 2016 21, 21-40.

Veselý, L., Perlín, K. 2010: Zajištování starých důlních děl [online]. In: DocPlayer (c) 2020. [cit. 20. 5. 2020]. Dostupné z: https:// docplayer.cz/docview/48/23941170/.

Vorel, P. 1999: Páni z Pernštejna. Vzestup a pád rodu zubří hlavy $v$ dějinách Čech a Moravy. Praha: Rybka Publishers.

Vosáhlo, J. 1996: Metody vyhledávání a průzkumu stř́ibrorudných ložisek v rozmezí 13. až 18. století (se zřetelem k Jihlavskému rudnímu revíru). In: K. Malý (ed.): Stříbrná Jihlava. Sborník př́spěvků ze seminářre $\mathrm{K}$ dějinám hornictví a důlních prací na Vysočině, Jihlava, 16. 9. - 17. 9. 1995. Jihlava: Muzeum Vysočiny, Státní okresní archiv Jihlava, 29-44.

Waldhauser, J., Daněček, V., Nováček, K. 1993: Eine hochmittelalterliche Aufbereitungsanlage für goldhaltige Erze im Bergbaurevier von Kašperské Hory (Bergreichenstein) in Böhmen. In: H. Steuer, U. Zimmermann (eds.): Montanarchäologie in Europa. Berichte zum Internationalen Kolloquium „Frühe Erzgewinnung und Verhüttung in Europa“ in Freiburg im Breisgau vom 4. bis 7. Oktober 1990. Sigmaringen: Jan Thorbecke Verlag, 391-400.

Wegner, M., Schubert, M. 2015: Die Grabung Roter Hirsch. Hochmittelalterliche Wohn- und Werkstätten der Dippoldiswalder Bergleute. In: R. Smolnik (ed.): ArcheoMontan 2015.

Montanarchäologie im Osterzgebirge. Montánní archeologie ve východním Krušnohoří. Dresden: Landesamt für Archäologie Sachsen, 207-244.

Weisgerber, G. 1998: Montanarchäologische Untersuchungen auf dem Altenberg. Zum mittelalterlichen Berg- und Hüttenwesen im Siegerland. In: C. Dahm, U. Lobbedey, G. Weisgerber: Der Altenberg. Bergwerk und Siedlung aus dem 13. Jahrhundert im Siegerland. Band 1: Die Befunde. Bonn: Dr. Rudolf Habelt GmbH, 133-219.

Weizsäcker, W. 1929: Sächsisches Bergrecht in Böhmen. Das Joachimsthaler Bergrecht des 16. Jahrhunderts. Reichenberg: Verlag Gebrüder Stiepel Ges. m. b. H.

Wolfskron, M. von 1889: Die Goldvorkommen Mährens. Berg- und Hüttenmännisches Jahrbuch der $k$. $k$. Bergakademien zu Leoben und Přribram und der königlich ungarischen Bergakademie zu Schemnitz XXXVII, 229-268, tab. V. 
Wolný, G. 1858: Kirchliche Topographie von Mähren, meist nach Urkunden und Handschriften. II. Abtheilung. Brünner Diöcese. II. Band. Brünn: Selbstverlag des Verfassers.

ZDB: Die Landtafel des Markgrafthumes Mähren. Brünner Cuda. Edd. P. R. v. Chlumecky, J. Chytil, C. Demuth, A. R. v. Wolfskron. Brünn 1856: auf Kosten vieler Mitglieder des begüterten Erbadels dieses Landes. Moravské zemské desky. III. 1567-1641. Kraj Brněnský. Ed. M. Rohlík. Praha 1957: Státní pedagogické nakladatelství Praha.

Zeiler, M., Garner, J., Golze, R., Steffens, G., Thomas, P. 2015: Neue Erkenntnisse zum spätmittelalterlichen Bergbau im Siegerland anhand der Grube Victoria bei KreuztalBurgholdinghausen. Der Anschnitt 67(2-3), 54-73.

Zimmermann, U. 1993: Untersuchungen zum frühen Bergbau im Südschwarzwald. In: H. Steuer, U. Zimmermann (eds.): Montanarchäologie in Europa. Berichte zum Internationalen Kolloquium „Frühe Erzgewinnung und Verhüttung in Europa“ in Freiburg im Breisgau vom 4. bis 7. Oktober 1990. Sigmaringen: Jan Thorbecke Verlag, 201-229.

Zycha, A. 1900a: Das böhmische Bergrecht des Mittelalters auf Grundlage des Bergrechts von Iglau. Erster Band: Die Geschichte des Iglauer Bergrechts und die böhmische Bergwerksverfassung. Berlin: Verlag von Franz Vahlen.

Zycha, A. 1900b: Das böhmische Bergrecht des Mittelalters auf Grundlage des Bergrechts von Iglau. Zweiter Band: Die Quellen des Iglauer Bergrechts. Berlin: Verlag von Franz Vahlen.

Žemlička, J. 2014: Království v pohybu. Kolonizace, města a stř́ibro v závěru přemyslovské epochy. Praha: Nakladatelství Lidové noviny.

\section{Summary}

\section{Introduction}

The $13^{\text {th }}$ and $14^{\text {th }}$ century silver mining and processing area in the Havírna forest near Štěpánov nad Svratkou is one of the most well-preserved mining sites in the European context. The exploration of the site, performed since the 1990s mainly under the auspices of the Institute of Archaeology of the Czech Academy of Sciences, Brno, pointed to its great potential for understanding the process of exploitation and refining of precious metals in an important period of Czech history (e.g., Klápště 2016, 182-183). Havírna (in translation "mining place") is the most important historical mining area of the Štěpánov polymetallic ore district. It features the occurrence of precious and non-ferrous metals and their former mining in the rugged landscape of the Nedvědice Highlands in north-western Moravia (Fig. 1).

Geological-mineralogical prospecting specified the characteristics of the deposit; mined ores contained, besides general sulphides with a predominance of sphalerite and galena, also an abundance of noble silver minerals, especially freibergite and pyrargyrite (e.g., Malý, Dolníček 2005, 310, 312-318, Fig. 2, 3, tab. 1-4: 10.1). The systematic surface archaeological survey presented Havírna as an unfortified complex, the sloping terrain of which included mines (both near-surface and deep), adjacent treatment and metallurgical workplaces as well as relics of mining service facilities and numerous mining houses. The mining area in total covered about 20 hectares (Fig. 2).

A comparison of written and archaeological sources allows us to place the opening of the deposit in Havírna in the middle of the $13^{\text {th }}$ century; the mining activity probably peaked in the following three decades. At the end of the reign of King Wenceslas II ( $†$ 1305), there was probably a considerable decline in mine workings; around the middle of the $14^{\text {th }}$ century, probably only a "hereditary", drainage adit was maintained to preserve mining rights. Attempts to restore exploitation took place in the late $15^{\text {th }}$ and $18^{\text {th }}$ centuries but were not very successful. The role of the landlord in Havírna throughout the period of the Middle Ages was held by one of the most important aristocratic families in Moravia, the lords of Medlov (or later of Pernštejn), and the Augustinian monastery in Doubravník could also claim certain rights there. However, the city patricians, especially the Brno ones, became extensively involved in the mining of precious metals in the entire Štěpánov ore district in the time of the Přemyslid and Luxembourg reign. According to late documents from 1348, 1350 and 1352, these included mainly the Goblin family, an ancestor of which held the office of the mint master at the end of the $13^{\text {th }}$ century.

Numerous archaeological finds, obtained by metal detector prospecting, provide important clues to the development of the internal structure of the whole complex, its social topography, the technique of exploitation and processing of mined ores and the material and spiritual culture of $13^{\text {th }}$ century mining communities. It was also possible to identify two central settlement districts subsequent in time. The older one was situated in the most advantageous centre of the site in terms of communication in the second half of the $13^{\text {th }}$ century. The substantially reduced settlement in the $2^{\text {nd }}$ third of the $14^{\text {th }}$ century was then concentrated only on the northern lower edge, near the mouth of the drainage adit (col. Doležel, Sadílek 2004)

\section{Documentation and prospecting project 2017-2019}

In the years 2017-2019, a joint research project focused on two current segments of the mining area study. The Institute of Archaeology of the Czech Academy of Sciences, Brno (supervisor Jiří Doležel) carried out a detailed survey of the site using the method of ground-based laser scanning. An additional activity was the re-prospecting of the site with a metal detector and a surface survey of other abandoned mining areas in the Štěpánov ore district. The Museum of Vysočina Jihlava (supervisor Karel Malý) carried out a detailed mineralogical research of ores, heavy minerals prospecting (panning), an analytical study of the chemical and phase composition of metallurgical slags, as well as chemical and phase analyses of found metal ingots. Financial support was provided by the Programme of Regional Cooperation of the Regions and Institutes of the Czech Academy of Sciences with the Vysočina Region.

The outputs of the project work in both segments expand the foundations for further knowledge of this key site as well as for its heritage preservation and presentation to the general public. The provisional results of the study of exploited ores in Havírna and their metallurgical processing are included in a summary by Karel Malý in the Acta rerum naturalium journal (Malý 2020). Above all, the research proved the application of technologically advanced metallurgical processes directly within the site. The present paper summarises the preliminary results of the documentation of the mining area, especially as regards new knowledge about its internal layout, the nature and scope of mine workings, possible treatment and metallurgical facilities, as well as service and housing infrastructure.

\section{Detailed localisation and mapping of the mining area, questions of interpretation}

\subsection{Development of cartographic representations of Havírna}

The oldest known cartographic representation of the mining complex is a schematic topographic map in a treatise from 1889 on Moravian deposits of gold (Fig. 3). The first more detailed mapping by geologist and mineralogist Adolf Polák probably 
comes from the 1930s or 1940s. The unfinished plan aptly captured the concentration of the shafts in the three main zones and their course, but missed numerous other mine workings (Fig. 4). During the deposit survey, localisation of the then excavated older drainage adit, Václav, in the north-western edge of the mining field was performed in 1959 (Fig. 5).

A shift in the cartographic depiction of Havírna was brought about by a map sketch, prepared as a part of student work in 1979 by Roman Štancl (Fig. 6). For the first time, the entire mining area was comprehensively depicted, including unclear or peripheral anthropogenic structures, and despite certain disproportions, it was therefore further used or modified in other publications. An exact, comprehensive geodetic mapping of the exploitation area was performed only in the years 2008-2010 during the survey and securing of the mining remains of the Štěpánov ore district (Fig. 7). However, its usefulness is limited by the schematic representation of the relief remnants of mining and the omission of almost all other anthropogenic formations outside the mining activity.

The development of aerial laser scanning has dramatically changed the possibilities of survey and objective capturing also in the case of a specific category of old mining areas (methodically e.g., Asrih 2013). The data from the $5^{\text {th }}$ generation digital relief model of the Czech Republic (DMR 5G) were applied during the heritage presentation of Havírna, and the published map (Stránská 2015, 364) clearly presented the entire mining site.

\subsection{Ground-based laser scanning of the site}

The project for the years 2017-2019 mapped in detail the terrain relief of the mining area in its documentation part. The aim was to minimise the subjective perspective and create a reliable, objective basis for subsequent analysis and functional and spatio-temporal classification and interpretation of individual anthropogenic features, their stratigraphy, position and involvement in the system structure within sub-segments as well as the site as a whole. This would allow us to get to know the partial functional components of the mining complex in more detail: mining areas, settlement areas, central and service points, treatment, metallurgical and workshop facilities, etc. However, the law and operational measuring of the mining fields using specific exploration and mining claims, specification of the organisation and holding of mining property as well as law-technical forms of exploitation and refining of mined ores were also important. The application of detailed ground-based laser scanning of the terrain seemed to be the most suitable method in these circumstances; it had previously been experimentally verified by the author at other mining sites.

The documentation of the Havírna mining area by this method was performed for the $765 \times 545 \mathrm{~m}$ terrain segment, covering an area of $26.44 \mathrm{ha}$. The resulting digital terrain model was created in a contour line representation with a contour interval of $0.2 \mathrm{~m}$, a regular grid of points with a spacing of $0.2 \mathrm{~m}$, and in the relevant $3 \mathrm{D}$ visualisations. The mapping fulfilled the set goals and proved the great efficiency of ground-based laser scanning for the documentation of large, extremely rugged and geomorphologically complicated complexes of anthropogenic relics of medieval mining and associated activities. The standardisation of the procedures used in the documentation of abandoned mining areas also encouraged their application in other mining districts (Jeseníky Mountains).

\subsection{On the interpretation of the spatial, functional} and community infrastructure of Havírna near Štěpánov

Detailed mapping of the area opens up mainly the possibility of objective functional-structural, technical and cultural-historical studying and interpretation of the entire mining area (Fig. 8-10). However, an important intermediate element remains the detailed identification, analysis and subsequent interpretation of all anthropogenic relics captured by mapping in a formal-functional sense also in terms of time classification and horizontal and vertical stratigraphy. Preliminarily, however, it is possible to characterise the initial terrain situation and comment on some aspects.

\subsubsection{Mine workings, the question of drainage adit and applied mining measures}

Relief traces of medieval mining and associated features in the Havírna forest can be found over an area of 20.7 ha. What is striking are the three main routes of shafts or pits, used for mining ore accumulations in individual directional vein zones (Fig. 8-15). The middle strip of old shafts, doubled in the northwest, reaches a total length of at least $610 \mathrm{~m}$, the not very compact southern line with some directional turns is $430 \mathrm{~m}$ long, while the northern one is $390 \mathrm{~m}$ long. The northern line of shafts is then crossed almost vertically by a shorter, 160-170 $\mathrm{m}$ long transverse line of several other pits. However, rather than ventilation shafts of the drainage adit, these are works on the transverse ore veins. A trace of the "hereditary", drainage adit is probably the outflow of mine waters below the north-western end of the northern mining line, in the lowest level of the area. The height difference between the assumed mouth of the adit and the highest mines is $120 \mathrm{~m}$; theoretically the depth of mine workings at Havírna could reach at least this level, the length of the drainage adit was then more than $500 \mathrm{~m}$.

As a mining area that was abandoned basically at the beginning of the $14^{\text {th }}$ century and remained well preserved, Havírna near Štěpánov offers great potential for studying the measurement of medieval mining areas and the size of mining claims in the Czech lands according to the old Czech mining law (Jihlava mining law or Ius regale montanorum of King Wenceslas II.: basic editions are brought by CDB IV.1, 290-328, No. 177, V.2, 596-610, No. 873; Zycha 1900b, 1-297; Bretholz 1903, 205-281; Hoffmann 1959, 31-63; Bílek 2000a, 17-84). The basic mining claim, seven fields long and four and a half fields wide (approximately $98 \times 63 \mathrm{~m}$ ), may correspond to several groupings on individual shaft lines, for example, a series of pits at the eastern end of the northern mining zone (cf. Fig. 8; 16). The classic "full" mining claim unit of $182 \times 63 \mathrm{~m}$, with thirteen fields, including the added royal, manorial and city fields, could then correspond to several structures of exploitation works. Among others, these are shafts at the south-eastern end of the southern mining line (Fig. 8; 17). Theoretically, the setting of six to seven complete mining claims is possible in Havírna.

The most striking element here, however, are the concentrated three shafts, regularly spaced in an area $20 \mathrm{~m}$ in length (17-22 m; perhaps up to six similar groupings; cf. Fig. 8; 18). These groupings may correspond to a protective find mining field with an area of two fields, with a measured protection zone of one field on each side of the found pit, and a total length of about $28 \mathrm{~m}$. Similar groups of three shafts are common in other mining localities in the Štěpánov ore district.

Documentation of mine workings at Havírna can also bring valuable knowledge about the methods of searching for ore accumulations in the Middle Ages. These are mainly isolated shafts outside the main exploited structures. These unfinished 
prospecting shafts can also preserve specific traces of the original arrangement of the pit and the shaft mouth itself.

\subsubsection{Problem of localisation of treatment and metallurgi- cal facilities and the use of water energy}

Primary treatment of the mined ores, subsequent preparatory operations and the smelting of the obtained concentrates into the final product was performed, as all the findings indicate, directly at the site. Massive concentrations of charcoal and slag after smelting of iron and polymetallic ores were found on larger terraces with more complex division in sloping terrain (Fig. 20, 21). There are also remnants of probably pyrometallurgical features (Fig. 22, 23).Similarly designed arrangements are known from many analogous European cases.

For the primary treatment of mined ores, the only stable source of water energy available at Havírna near Štěpánov was a stream on the northern edge of the area. Heavy minerals prospection (K. Malý) proved the presence of slags from the smelting of polymetallic ores in the stream bed, mostly directly on the north-eastern edge of the mining area: this is where the smelting or subsequent operations could have taken place. According to the analyses, the slags from the stream show unusually high lead content (7.6-39 wt. \% Pb); this probably indicates technological procedures applied in the smelting of noble, rich silver ores. The advanced level of metallurgy at the site is also indicated by the material composition of some metal ingots from the mining complex. They correspond to so-called black copper as a by-product after smelting of high-quality galena-freibergite concentrate.

\subsubsection{Settlement and service segments of Havírna near Stěpánov}

The medieval mining settlement of Havírna fully fits into the concept of mining settlements in Europe in the Middle Ages. That corresponds to the cosmopolitan character and specialisation of the then mining society. In addition to the basically temporary and at the same time conjunctural nature, the mining settlements shared a close spatial and functional connection to the mine workings themselves and to the treatment and metallurgical facilities. They were also characterised by a maximally purposeful system composition, mostly a utilitarian urban concept, but with a strong tendency towards normative modules. The combination of an above-ground wooden structure with archaeologically striking sunken basements, probably related to the dominantly consuming character of medieval mining communities, was also very common. In Havírna, there is also a strikingly rich archaeologised material culture, probably reflecting the mental disposition of the inhabitants of these sites (cf. Bailly-Maître 2002, 167-175; Steuer, Goldenberg 2002; Schwabenicky 2011, 17-22; Derner 2015, 110-126).

The interpretation potential is increased here by both the excellent preservation of the surface relief and the location of the mining area mainly in heavily sloping terrain, which forced consistent terracing of the slopes for any construction activity. The Havírna settlement area is thus indicated mainly by these terraces together with the relevant basements, in some cases also multi-space and with stone-reinforced walls. Based on the new mapping, the basic module of the Štěpánov Havírna settlement area appears to be highly diversified; both social-law and economic-functional reasons lay behind this diversity. The same applies to some mining settlements studied so far, characterised by a rather wider dispersion of individual settlement clusters or components (collectively in the urban planning of these units, e.g., Kenzler 2012, 155-162; 2014, 161-162, 166, Fig. 6, 7; Derner 2015, 111-114, Fig. 4, 5).
In total, at least three differently organised settlement segments can be distinguished at Havírna near Štěpánov. The possible significance of the concentration of settlement features of the second half of the $13^{\text {th }}$ century in the central part of the complex was confirmed (Fig. 8; 24). The features form a concentrated formation, with the longest side approximately $65 \mathrm{~m}$ in length. The whole structure, with hints of an orthogonal layout, implies the hypothetical image of the settlement-administrative headquarters of the entire mining area.

The second complex of approximately thirty settlement terraces can be seen in Havírna on the slope above the stream on the northern edge of the mining area, on a strip $290 \mathrm{~m}$ long and 50 m wide (Fig. 8, 25, 26). In addition, the composition of several features of different types allows us to consider more complex structured settlement units. The area was used both in the second half of the $13^{\text {th }}$ and at the beginning of the $14^{\text {th }}$ century. In the small western segment, however, the settlement remained throughout the $14^{\text {th }}$ century (Fig. 27). Its likeness to the village of Hohenrod known from 1348 remains a question; it could be related to the operation of the nearby drainage adit as the last maintained part of the entire mining area.

A significant formation of about twenty terraces accompanies the path on a $200 \mathrm{~m}$ long strip in two rows, from the west across the ascending slope in the western part of the site (Fig. 28). However, a safe interpretation of this concentration as another settlement area of the mining complex is not yet possible, as so far there is a lack of more demonstrable evidence of residential use. It is also possible to assume other more dispersed settlement clusters or individual dwellings and guild buildings directly at the shafts or other structures (Fig. 29, 30).

\subsubsection{Sacral building at Havírna?}

With regard to the character of Havírna as the central mining area of the Štěpánov ore district, a legitimate question is the existence of a sacral building, probably a chapel, within the mining area itself; features of this type are quite abundantly documented in many mining districts in Europe in the Middle Ages (generally Schreiber 1962, vol. 35-87, 211-229, 303-422, 450-475; also, e.g., Bailly-Maître, Bruno-Dupraz 1994, 173-179; Rauschkolb 1999; Bailly-Maître 2002, 160-167; Goldenberg, Steuer 2004, 67-69; Neuhauser 2013, 33-39, Fig. 4, 5, 7, 8, 10). However, there is a lack of any reliable indications of an analogous foundation at Havírna, although further research could be decisive. In the sphere of spiritual administration, however, the local mining area was probably connected to the nearest settlement center, Štěpánov nad Svratkou, with the parish church of St Peter and Paul, probably built before the middle of the $13^{\text {th }}$ century (Fig. 31).

\subsubsection{On the law base of the settlement at Havírna near Štěpánov: the importance of the measured mountain and the deepest drainage adit}

The origin and existence of medieval settlements near mines was made possible by the old Czech mining law in general in several cases (cf. Derner 2015, 111, 114, 116). It stimulated the efficient exploitation of exposed deposits and the conjunctural boom in the most important mining districts.

According to Jihlava law from the second half of the $13^{\text {th }}$ century and according to the Ius regale montanorum of King Wenceslas II (1300-1305), for each properly measured mine unit of seven mining fields, sixteen free land plots (area) for dwellings could be created. In addition, the Ius regale added a legal right to land for grazing cattle around the measured mine unit within the shooting range of a bow, i.e., within a radius of approximately 200-260 m. Even more widely, both norms privileged the drainage 
adit, which was excavated deepest and thus drained the entire wider mining area: such a mine working was to receive as many sixteen-settlement units as many measured seven-field mine units would be drained by it (CDB IV. 1, 325, č. 177, art. IIa; Zycha 1900b, 10 [§ 9], 23 [§ 8], 134-135 [Lib. II, Cap. 3/I, § 1], 156-157 [Lib. II, Cap. 4/V, § 23, 24]; Bretholz 1903, 233 [III], 239 [IV]; cf. Zycha 1900a, 180-182). In addition, the newer versions of the Jihlava mining law granted all drainage adits the same territory for the grazing of cattle of miners delimited within the bow shooting range, as was the case with the measured seven-field mining fields (Zycha 1900b, 24, § 12).

In this respect, the mining legislation thus met the miners' wishes and, to a lesser extent, the royal fiscal purposes, and also the interests of the landlords. The number of sixteen areas was related both to the provision of standard operation of the open measured mine and to the capital distribution of mining assets.

Other fixed requirements of free mining settlements were specified in more detail in the sentences of the Jihlava Mining Court during the $14^{\text {th }}$ and at the beginning of the $15^{\text {th }}$ century (Tomaschek 1897, 46-47, 65-66, 101-102, 135-136, no. 84-86, 93, 112, 124; Zycha 1900a, 148-149, 180-183; 1900b, 335-338, No. 27-32; Balášová, Burghardt 2018; Sternberg, Sterly 1837, 87-88, No. 65). The facilities of the measured mines and privileged adits included the necessary numbers of meat and bread shops, baths, free market privileges and a beer, mead and wine taprooms. The goodwill of the lord of the land was desirable for the construction of buildings on the measured mining areas; construction was to be done only directly within the relevant mining area, but the builders were guaranteed free access even with wagons (Zycha 1900b, 335-337, No. 27-30).
Archaeological findings confirm compliance with the set norms. Virtually all mining settlements identified so far in the medieval mining districts of Bohemia and Moravia are tied to mines with an area of at least one fully measured unit; on the contrary, they are missing in exploratory or limited mine workings. In this context, it is also possible to consider the upper limits of the frequency of settlements in Havírna, where we can hypothetically assume more than fifty simultaneously settled areas.

\section{Conclusion}

The acquired detailed planning documentation of Havírna opens up the possibility of objective evaluation, preservation and presentation of this important mining site. However, the present text can only be an initial working balance point before further research stages and a possible overall publication. Closer field identification of all anthropogenic relics captured by measurements is necessary, as well as the wide application of geophysical prospecting methods and archaeological excavations, affecting at least the basic components of the functional structure of the site. Heritage preservation is also crucially important.

\section{Kontakt}

\section{Jiří Doležel}

Archeologický ústav AV ČR, Brno, v. v. i.

Čechyňská 19

CZ-602 00 Brno

dolezel@arub.cz 